\title{
Discovery of a New Class of Potent, Selective, and Orally Bioavailable CRTH2 (DP2) Receptor Antagonists for the Treatment of Allergic Inflammatory Diseases ${ }^{\#}$
}

\author{
Stefano Crosignani, ${ }^{\dagger}$ Patrick Page, ${ }^{\dagger}$ Marc Missotten,${ }^{\dagger}$ Véronique Colovray, ${ }^{\dagger}$ Christophe Cleva, ${ }^{\dagger}$ Jean-François Arrighi, ${ }^{\dagger}$ \\ John Atherall, ${ }^{\S}$ Jackie Macritchie,${ }^{\S}$ Thierry Martin, ${ }^{\dagger}$ Yves Humbert, ${ }^{\dagger}$ Marilène Gaudet, ${ }^{\dagger}$ Doris Pupowicz, ${ }^{\dagger}$ Maurizio Maio, ${ }^{\dagger}$ \\ Pierre-André Pittet, ${ }^{\dagger}$ Lucia Golzio, ${ }^{\ddagger}$ Claudio Giachetti, ${ }^{\ddagger}$ Cynthia Rocha, ${ }^{\ddagger}$ Gérald Bernardinelli, ${ }^{\triangle}$ Yaroslav Filinchuk, ${ }^{\perp}$ \\ Alexander Scheer, ${ }^{\dagger}$ Matthias K. Schwarz, ${ }^{\dagger}$ and André Chollet*, ${ }^{\dagger}$ \\ Merck Serono International S.A., 9 chemin des Mines, 1202 Geneva, Switzerland, Istituto di Ricerche Biomediche A. Marxer, Merck Serono, \\ I-10010 Colleretto Giacosa, Italy, BioFocus DPI, Saffron Walden, Essex CB10 1XL, U.K., Laboratory of X-Ray Crystallography, University of \\ Geneva, 1211 Geneva 4, Switzerland, and Swiss-Norwegian Beam Line, ESRF, F-38043 Grenoble, France
}

Received November 5, 2007

A novel chemical class of potent chemoattractant receptor-homologous expressed on Th2 lymphocytes (CRTH2 or DP2) antagonists is reported. An initial and moderately potent spiro-indolinone compound (5) was found during a high-throughput screening campaign. Structure-activity relationship (SAR) investigation around the carboxylic acid group revealed that changes in this part of the molecule could lead to a reversal of functional activity, yielding weakly potent agonists. SAR investigation of the succinimide functional group led to the discovery of several single-digit nanomolar antagonists. The potency of these compounds was confirmed in a human eosinophil chemotaxis assay. Moreover, compounds $(R)-\mathbf{5 8}$ and $(R)-\mathbf{7 1}$ were shown to possess pharmacokinetic properties suitable for development as an orally bioavailable drug.

\section{Introduction}

Prostaglandin D2 (PGD2, 1, Figure 1) is the major prostanoid species produced by mast cells in response to stimulation by allergens and plays a key role in inflammatory processes. PGD2 exerts its effect through two high-affinity G-protein-coupled receptors: the classical DP receptor and the recently discovered chemoattractant receptor-homologous expressed on Th2 lymphocytes (CRTH2 also known as DP2). ${ }^{a}$ In humans, CRTH2 is predominantly expressed by Th2 cells, eosinophils, and basophils all known to play a key role in allergic diseases. ${ }^{1}$ Activation of the Gi-coupled CRTH2 by prostaglandin D2 (PGD2) or the selective agonist DK-PGD2 (2) (Figure 1) stimulates chemotaxis of human Th2 cells, eosinophils, and basophils, in vitro and in vivo, ${ }^{2,3}$ suggesting that the CRTH2 receptor may directly mediate the recruitment of inflammatory cells in allergic diseases such as asthma, allergic rhinitis, and atopic dermatitis. Severity of atopic dermatitis has been correlated with increased numbers of circulating Th2 cells. ${ }^{4}$ Atopic dermatitis subjects or those with sensitivity to pollen or to dustmite antigens have significantly increased levels of CD4+ T cells expressing CRTH2 receptors. ${ }^{2,5,6}$ CRTH2 is expressed by Ag-specific Th2 cells in allergic individuals, supporting the notion that $\mathrm{CRTH} 2$ receptor is important in the recruitment of Th2 in allergic diseases in humans. ${ }^{7}$ Finally, sequence variants of the CRTH2 receptor that confer increased mRNA stability

\footnotetext{
${ }^{\#}$ Dedicated to the memory of Dr. Serge Halazy.

* To whom correspondence should be addressed. Phone: +41224149826 Fax: +41224149565. E-mail: andre.chollet@merckserono.net.

${ }^{\dagger}$ Merck Serono International S.A.

$\S$ BioFocus DPI.

\# Merck Serono.

${ }^{\triangle}$ University of Geneva.

${ }^{\perp}$ ESRF.

${ }^{a}$ Abbreviations: ADME, absorption-distribution-metabolism-excretion; CRTH2, chemoattractant receptor-homologous expressed on Th2 lymphocytes, also known as DP2; DMF, dimethylformamide; DMSO, dimethyl sulfoxide; NOE, nuclear Overhauser effect; Papp, permeability coefficient; PGD2, prostaglandin D2; SAR, structure-activity relationship.
}

are associated with a higher degree of bronchial hyperresponsiveness and the occurrence of fatal asthma. ${ }^{8}$

Further data in animal models likewise point to a potential role for CRTH2 modulation in allergic disorders. CRTH2 receptor activation induces the release of eosinophils from guinea-pig bone marrow. ${ }^{9}$ In mouse models of allergic asthma and atopic dermatitis, CRTH2 receptor activation promotes eosinophilia and exacerbates pathology. ${ }^{10}$ Intratracheal administration of PGD2 in rats, pretreated with systemic IL-5 injection or not, induces eosinophil trafficking into the airways. This effect is mimicked by selective CRTH2 receptor agonists but not by a DP (DP1) selective agonist. ${ }^{3,11}$ Inhibition by selective small molecules of the CRTH2 receptor but not of the DP or TP receptor abolishes inflammatory responses in a mouse model of contact hypersensitivity. ${ }^{12}$ Quite surprisingly, mice lacking the functional gene that encodes $\mathrm{CRTH} 2$ show enhanced eosinophil recruitment and increased IL-5 production by splenocytes, suggesting that $\mathrm{CRTH} 2$ limits rather than enhances inflammation. ${ }^{13}$ Recently, it has been postulated that DP and CRTH2 might have opposite effects in complex inflammatory processes. $^{14}$

PGD2 is enzymatically and nonenzymatically metabolized into many different products, several of which are biologically active. ${ }^{14,15}$ The thromboxane A2 antagonist ramatroban (3) (Figure 1), a drug marketed for allergic rhinitis, was shown to be also a potent $\mathrm{CRTH} 2$ antagonist. In addition, the finding that indomethacin (4) (Figure 1) was able to activate CRTH2, among other pharmacological actions, was the starting point for the discovery of other indole acetic acid derivatives and further spurred much effort in the pharmaceutical industry aimed at discovering selective agents to modulate its action. ${ }^{16}$ The availability of highly selective ligands will provide new insights on the role of CRTH2 in inflammatory processes.

We set out to discover and develop a new class of potent, selective, and orally active DP2 antagonists as potential new 
<smiles>CCCCC[C@H](O)/C=C/C1C(=O)C[C@@H](O)[C@@H]1C/C=C/CCCCC(=O)O</smiles><smiles>CCCCCC[C@H](O)CCC1C(=O)C[C@@H](O)[C@@H]1C/C=C/CCCC(O)O</smiles>

3<smiles>O=C(O)CCn1c2c(c3ccccc31)C[C@@H](NS(=O)(=O)c1ccc(F)cc1)CC2</smiles>

Figure 1. Structures of PGD2 (1), selective CRTH2 agonist DK-PGD2 (2), ramatroban (3), indomethacin (4), and a new spiro-indolinone compound (5) identified as a primary screening hit.

agents for the pharmacological management of allergic and inflammatory diseases.

\section{Results and Discussion}

Primary Screening Results. A high-throughput screening campaign based on a radioligand binding assay was performed on 19200 compounds selected for their potential to interact with G-protein-coupled receptors. Several spiro-indolinones were found as positive and confirmed in a dose-response $\mathrm{IC}_{50}$ determination experiment. In particular, it appeared that a carboxylic acid moiety was present in the most potent compounds (Table 1). The most potent compound was 5 with $K_{\mathrm{i}}$ values of 196 and $150 \mathrm{nM}$ for human and mouse CRTH2, respectively, in a competitive ${ }^{3} \mathrm{H}-\mathrm{PGD} 2$ binding assay. The very preliminary structure-activity relationship (SAR) that could be obtained from this limited set of compounds also suggested that the presence of a lipophilic substituent on the succinimide nitrogen could have a beneficial effect, as compared to that of a simple methyl group or nonaromatic substituent (e.g., 10, $K_{\mathrm{i}}$ $=3829 \mathrm{nM}$ ).

Compound 5 was further evaluated in a receptor functional assay and assessed for early absorption-distributionmetabolism-excretion (ADME ) properties (Table 2). Testing of the compound in a GTP $\gamma \mathrm{S}$ binding assay showed antagonist activity $\left(\mathrm{IC}_{50}=418 \mathrm{nM}\right)$ and even inverse agonism $(-11 \%$ stimulation at $20 \mu \mathrm{M})$. The in vitro early ADME profile of $\mathbf{5}$ showed a remarkable stability toward oxidative metabolism in both rat and human liver microsomes but a poor permeability in the Caco-2 cell assay, as expected for a carboxylic acid. No inhibition effect on five major cytochrome P450 isoforms could be observed at $10 \mu \mathrm{M}$. The compound was shown to be more than 100-fold selective against other prostanoid receptors and also on a panel of 50 receptors and ion-channel pharmacological targets.

On the basis of these data, $\mathbf{5}$ was considered as a suitable starting point for lead optimization. In the following sections, we describe the SAR around the core structure, in particular

Table 1. Spiro-indolinone Compounds from High-Throughput Screening Campaign

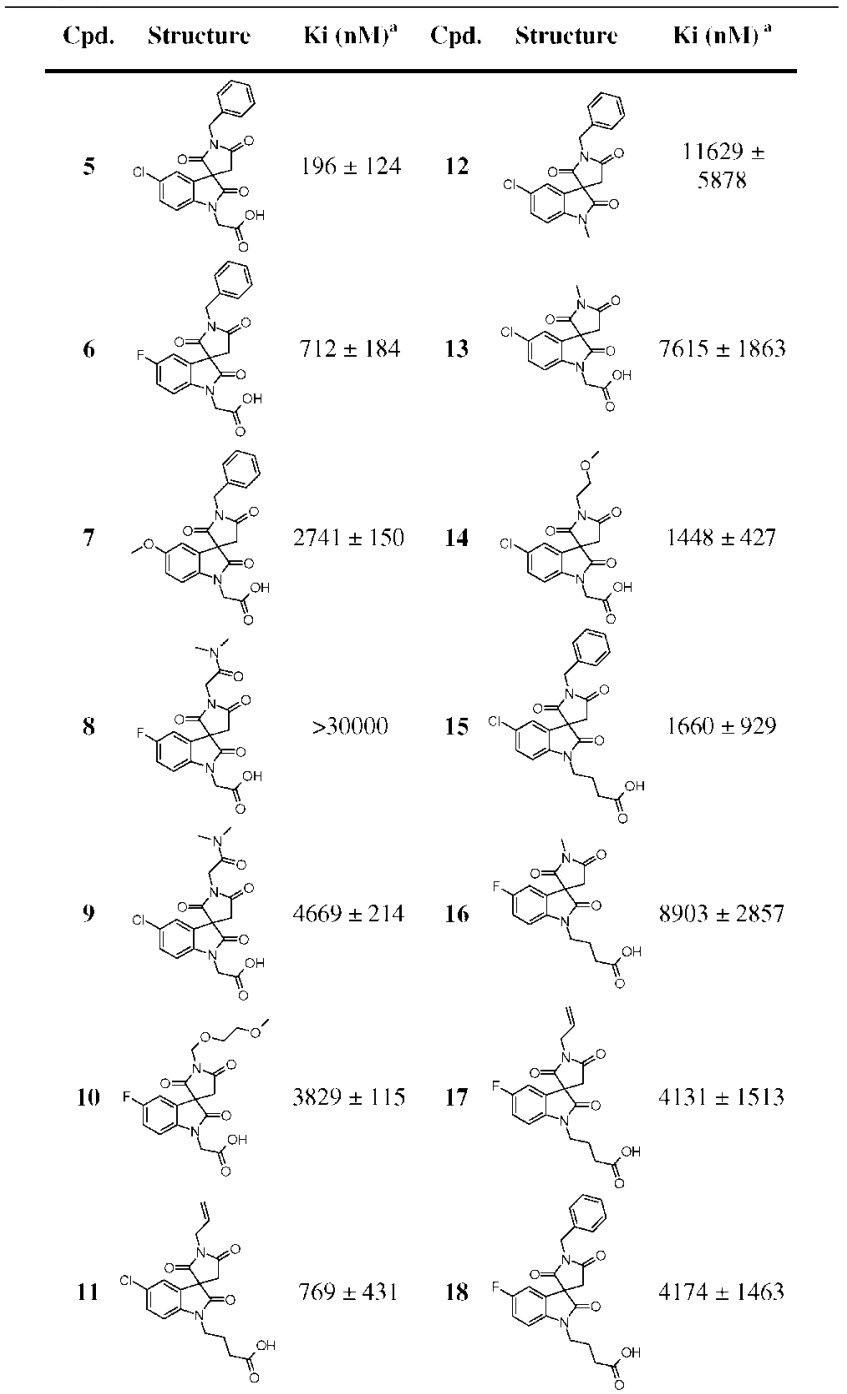

${ }^{a}$ Competitive displacement radioligand binding assay on human CRTH2 (see Experimental Section).

Table 2. Pharmacological and Early in Vitro ADME Profile of Hit 5

$K_{\mathrm{i}}$ binding $^{a}(\mathrm{hCRTH2})$
$K_{\mathrm{i}}$ binding $^{b}(\mathrm{mCRTH} 2)$
$\mathrm{IC}_{50} \mathrm{GTP} \gamma \mathrm{S}^{c}(\mathrm{hCRTH} 2)$
$\mathrm{Cl}(\mathrm{h}-\mathrm{LM})^{d}$
$\mathrm{Cl}(\mathrm{r}-\mathrm{LM})^{d}$
$\mathrm{IC}_{50}(1 \mathrm{~A} 2)^{e}$
$\mathrm{IC}_{50}(2 \mathrm{C} 19)^{e}$
$\mathrm{IC}_{50}(2 \mathrm{C} 9)^{e}$
$\mathrm{IC}_{50}(2 \mathrm{D} 6)^{e}$
$\mathrm{IC}_{50}(3 \mathrm{~A} 4)^{e}$
$\mathrm{Caco}-2(\mathrm{Papp})^{f}$

$196 \pm 124 \mathrm{nM}$

$150 \mathrm{nM}$

$418 \pm 95 \mathrm{nM}$

$0 \mu \mathrm{L} / \mathrm{min} / \mathrm{mg}$ protein

$9 \mu \mathrm{L} / \mathrm{min} / \mathrm{mg}$ protein

$>10 \mu \mathrm{M}$

$>10 \mu \mathrm{M}$

$>10 \mu \mathrm{M}$

$>10 \mu \mathrm{M}$

$>10 \mu \mathrm{M}$

$3.0 \times 10^{-6} \mathrm{~cm} / \mathrm{s}$

${ }^{a}$ Competitive displacement radioligand binding assay on human CRTH2. ${ }^{b}$ Competitive displacement radioligand binding assay on murine CRTH2. ${ }^{c}$ GTP $\gamma$ S radioligand binding assay. ${ }^{d}$ Microsome stability experiment. h-LM, human liver microsomes; r-LM, rat liver microsomes. ${ }^{e}$ Inhibition of cytochrome P450 isoforms. ${ }^{f}$ Caco-2 cell permeability assay (see Experimental Section). Papp, permeability coefficient.

with respect to the substituents on the succinimide and indolinone nitrogen atoms, as well as modifications of the succinimide moiety.

Chemistry. Hit 5 was readily prepared as depicted in Scheme 1. By using the commercially available chloroisatin $\mathbf{1 9}$ as the starting point, derivative $\mathbf{2 0}$ was obtained by Knoevenagel 


\section{Scheme $1^{a}$}<smiles>CCCC(C)C1(C(C)C)C(=O)Nc2ccc(Cl)cc2C1(C(C)C)C(C)C(C)C</smiles><smiles>[Z20]N1C(=O)C2(CC(=O)N(Cc3ccccc3)C2=O)c2cc(Cl)ccc2C12C(=O)N(CC(C)C)C(=O)C21CC(=O)N(Cc2ccccc2)C1=O</smiles><smiles>O=C(O)CN1C(=O)CC2(CC(=O)N(Cc3ccccc3)C2=O)c2cc(Cl)ccc21</smiles>

${ }^{a}$ Reagents: (a) Methyl cyanoacetate, piperidine. $\mathrm{MeOH}$, reflux, 90\%. (b) $\mathrm{KCN}, \mathrm{MeOH}, \mathrm{H}_{2} \mathrm{O}$, rt, $86 \%$. (c) $\mathrm{HCl}, \mathrm{MeOH}$, rt to reflux. (d) $\mathrm{AcOH}$, reflux, $66 \%$. (e) $\mathrm{KO} t \mathrm{Bu}, \mathrm{DMF}$, then benzyl bromide, rt, 73\%. (f) $\mathrm{NaH}$, THF, tert-butyl bromoacetate, rt, $91 \%$. (g) TFA, DCM, $0{ }^{\circ} \mathrm{C}$ to rt, $57 \%$.

\section{Scheme $2^{a}$}

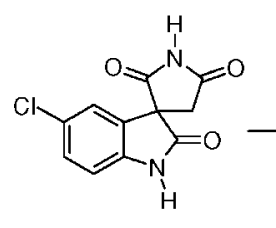

22

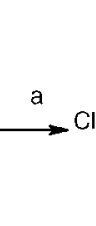

(aty<smiles>O=C1CC2(C(=O)Nc3ccc(Cl)cc32)C(=O)N1C[Al]</smiles>

25<smiles>CCOC(=O)N1C(=O)CC2(CCN(C[Al])C2=O)c2cc(Cl)ccc21</smiles>

26<smiles>[Y1]CN1C(=O)CC2(C1=O)C(=O)N([Y])c1ccc(Cl)cc12</smiles>

27

${ }^{a}$ Reagents: (a) KOtBu, DMF, then aryl bromide, r.t. (b) NaH, THF, then tert-butyl bromoacetate, r.t. or tert-butyl bromopropionate, reflux. (c) TFA, DCM, $0{ }^{\circ} \mathrm{C}$ to r.t.

\section{Scheme $3^{a}$}<smiles>O=C1CC2(C(=O)Nc3ccc(Cl)cc32)C(=O)N1Cc1ccccc1</smiles>

23

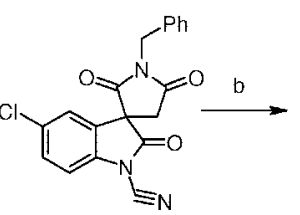

28

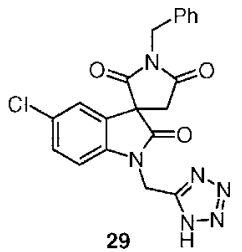

29

${ }^{a}$ Reagents: (a) $\mathrm{NaH}$ (1.1 equiv), DMF, then bromoacetonitrile $(0.95$ equiv). (b) $\mathrm{NaN}_{3}$ (1.5 equiv), $\mathrm{NH}_{4} \mathrm{Cl}$ (1.5 equiv), $\mathrm{DMF}, 125^{\circ} \mathrm{C}$.

reaction. Subsequent reaction with potassium cyanide, followed by cyclization under acidic conditions, generated the desired spirocycle 22. Alkylation with benzyl bromide predominantly occurred on the succinimide ring, and purification by column chromatography gave 23. The final alkylation was carried out with tert-butyl bromoacetate, and deprotection yielded the desired product $\mathbf{5}$.

By using the common intermediate $\mathbf{2 2}$ as the starting point, the same synthetic strategy was applied to investigate the SAR of the southern part of the molecule (Scheme 2). The reaction using tert-butyl-3-bromopropionate required stronger conditions than those for the corresponding bromoacetic ester, but the reaction was nonetheless successful. For the synthesis of tetrazole derivative 29, a two-step protocol was used (Scheme 3 ): intermediate $\mathbf{2 3}$ was alkylated with bromoacetonitrile, and the resulting nitrile was converted into the desired tetrazole by reaction with sodium azide.

In order to explore more efficiently the northern part of the molecule, a modification of the synthesis was sought; the original route would necessitate that the main diversity be

\section{Scheme 4}<smiles>CCCCCN1C(=O)CC2(CC(=O)N(P)C2=O)c2cc(Cl)ccc21</smiles>

introduced first, and then, the final alkylation with tert-butyl bromoacetate be carried out on all compounds. A more streamlined approach would be to reverse the order of reactions and alkylate on the indolinone nitrogen before the diversification step on the succinimide (Scheme 4).

Changing the conditions for the alkylation of the spiroindolinone-succinimide system, it was possible to switch its regioselectivity (Scheme 5); whereas the use of 1 equiv of potassium tert-butoxide led to alkylation on the succinimide nitrogen, the use of 2 equiv of sodium hydride gave rise exclusively to the product of alkylation on the indolinone nitrogen. In order to verify the identity of the products, nuclear Overhauser effect (NOE) experiments were performed. The structure of $\mathbf{3 3}$ was confirmed by the distinct NOE on $\mathrm{Hd}$ upon irradiation of Hc, whereas no such effect was seen for 34 (Figure 2).

Over 40 compounds were prepared rapidly by using the strategy depicted in Scheme 4. Because these molecules have a chiral center, they were first prepared and tested as racemates. The preparation of pure enantiomers was carried out for derivatives that displayed good potency in vitro and a good pharmacological profile. Possible strategies for the enantiose- 


\section{Scheme $5^{a}$}

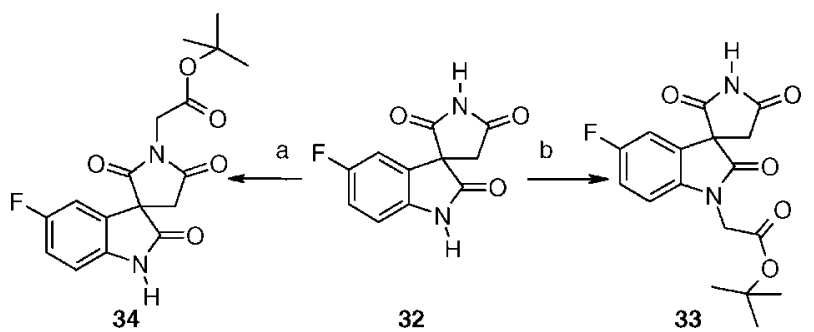

${ }^{a}$ Reagents: (a) KOtBu, DMF, then tert-butyl bromoacetate. (b) $\mathrm{NaH}$ (2.1 equiv), DMF, then tert-butyl bromoacetate ( 0.95 equiv).

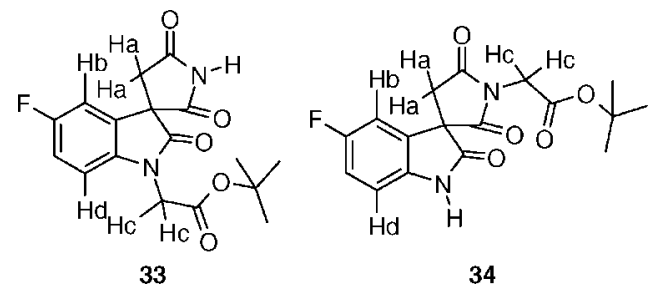

Figure 2. Elucidation of the regiochemistry of the alkylation by NOE.

lective syntheses were envisaged, but all entailed a large number of steps. As, at the time, the configuration of the active enantiomer was not known, it was decided to perform a chiral resolution in order to obtain both enantiomers for evaluation of the biological activity. Several attempts to perform the chiral resolution by crystallization of the carboxylic acids by using a variety of chiral bases failed to yield enantiomerically pure compounds (data not shown). However, several compounds could be separated by using preparative HPLC packed with a chiral stationary phase (see Experimental Section). The absolute configuration of the compounds was determined for three representative compounds $((R)-\mathbf{5},(R)-\mathbf{5 8}$, and $(S)-\mathbf{9 0})$ by single X-ray diffraction crystallography.

Synthesis of the spiro-4-pyrrolidinone compounds proved to be less straightforward. The synthesis of the spiro-4-pyrrolidinones $\mathbf{4 1}$ is outlined in Scheme 6. Intermediate $\mathbf{2 0}$ could be reacted with nitromethane in the presence of catalytic piperidine to give the 1,4-addition product 35 , which could be readily decarboxylated by ester hydrolysis followed by heating in dimethylformamide (DMF). Reaction with excess acetamide catalyzed by palladium dichloride converted the nitrile to the primary amide group. ${ }^{17}$ Reduction of the nitro group proved the most troublesome step in the sequence; among the many reducing agents that were tested, only zinc in hot acetic acid gave a clean reduction. Under the conditions used, spontaneous cyclization occurred to directly give the key spirocyclic intermediate 38. Sequential alkylation of the two amide moieties, first with tert-butyl bromoacetic acid, then with the appropriate benzyl bromide, followed by deprotection of the tert-butyl ester group with TFA, yielded the final products $\mathbf{4 1}$.

For the synthesis of the isomeric structure 50, the route starting from the described intermediate $\mathbf{4 3}^{18}$ was attempted first (Scheme 7). However, upon deprotection of the ester group, spontaneous decarboxylation was found to occur even under mild conditions. The same behavior was observed after basic hydrolysis of the ethyl ester derivative. However, construction of the spiro-cyclic system could be easily performed in a single step from 45, prepared as described by the procedure of Simig, ${ }^{18}$ by simple reaction of its sodium salt with 2-bromoethylisocyanate (Scheme 8). Subsequent hydrogenation on platinum dioxide gave the key intermediate 47 . The substituents on the two nitrogen atoms were then introduced by using the same strategy employed for the other pyrrolidinone derivatives (Scheme 8).

Biological Activity. At first, the SAR around of the southern part of the molecule, including the key carboxylic acid feature, was explored (Table 3). The importance of the carboxylic acid was confirmed by the fact that the corresponding ethyl ester derivative $\mathbf{5 1}$ proved to be very weakly active.

The length of the spacer connecting the carboxylic acid group to the indolinone core was found to be of crucial importance; whereas a two-carbon chain led to almost complete loss of potency (data not shown), a three-carbon chain (as was seen with the first set of commercial compounds) is allowed, although with about 10-fold loss of potency in the binding assay (e.g., 52, $K_{\mathrm{i}}=1759 \mathrm{nM}$ and 58, $K_{\mathrm{i}}=37 \mathrm{nM}$ ). Remarkably, these compounds exhibited a profound difference compared to the hit compound $\mathbf{5}$ when tested in the GTP $\gamma \mathrm{S}$ assay; whereas 5 behaved as an inverse agonist, all the compounds bearing a three-carbon chain exhibited full agonist behavior, with potencies similar to those obtained in the binding assay. This behavior can be rationalized by comparing the 3D structure of one- and three-carbon chain compounds with known antagonists and agonists. As shown in Figure 3, one-carbon chain compounds give a very good overlay with ramatroban, whereas three-carbon chain compounds give better results when overlaid with a CRTH2 agonist.

Finally, a derivative bearing a tetrazole (29), a well-known carboxylic acid bioisostere, was tested and found to be markedly less potent than $\mathbf{5}$.

After it was determined that the optimal substituent for the southern part of the molecule is a methylenecarboxylic acid, the SAR on the benzylic substituent was explored (Table 4). Initially, the spacer between the succinimide nitrogen and the aromatic group was investigated. A compound with a twocarbon chain (55) was found to be almost equipotent with $\mathbf{5}$, whereas the vinylogous compound $\mathbf{5 6}$ showed a 4-fold reduction in potency. Introduction of a branching on the spacer (57) led to a 2-fold reduction in potency, as well as the creation of a further stereocenter in the molecule.

Substitution on the phenyl ring gave rise to compounds that were generally more potent than the unsubstituted 5. Only the introduction of a methylsulfonyl group in the para position (65) led to a substantial loss of potency $\left(K_{\mathrm{i}}=1506 \mathrm{nM}\right)$. It is noteworthy that bulky groups $\left(-\mathrm{OPh}, \mathbf{6 4}, K_{\mathrm{i}}=143 \mathrm{nM}\right)$ were still accepted and showed a small increase in potency compared to 5 .

In general, halogens proved to be preferred substituents, and incorporation at the ortho and meta positions are particularly favored, for example, $o$-fluoro derivative $58\left(K_{\mathrm{i}}=37 \mathrm{nM}\right)$ and $m$-chloro derivative $60\left(K_{\mathrm{i}}=68 \mathrm{nM}\right)$, compared with the $m$-methoxy derivative $\mathbf{6 3}\left(K_{\mathrm{i}}=169 \mathrm{nM}\right)$. The effect of these substituents was furthermore found to be additive, so that the simultaneous presence of two halogens in ortho and meta positions led to some of the most potent compounds in this subseries: $71\left(K_{\mathrm{i}}=10 \mathrm{nM}\right), \mathbf{6 6}\left(K_{\mathrm{i}}=25 \mathrm{nM}\right)$, and $\mathbf{6 8}\left(K_{\mathrm{i}}=37\right.$ $\mathrm{nM})$.

The high activity demonstrated by $\mathbf{7 6}\left(K_{\mathrm{i}}=38 \mathrm{nM}\right)$, in which the substitution of the phenyl ring of $\mathbf{5}$ with a thiazole led to a 5-fold improvement in potency, led us to explore the effect of heterocycles in this position (Table 5). Modification of the 2-methyl substituent on the thiazole moiety with substituted phenyl groups gave rise to two other interesting compounds with comparable activities $\left(77, K_{\mathrm{i}}=24 \mathrm{nM}\right.$ and $\mathbf{7 8}, K_{\mathrm{i}}=55$ $\mathrm{nM})$. Replacement of the thiazole with oxazole, oxadiazole, or 


\section{Scheme $6^{a}$}<smiles>COC(=O)C(C#N)=C1C(=O)Nc2ccc(Cl)cc21</smiles><smiles>CC(C)C1(CC(N)=O)C(=O)Nc2ccc(Cl)cc21</smiles>

35
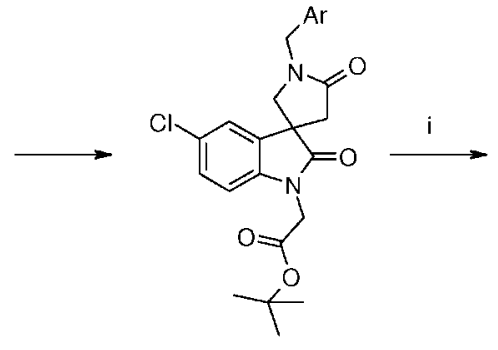<smiles>O=C1CC2(CN1)C(=O)Nc1ccc(Cl)cc12</smiles>

38<smiles>O=C(O)CN1C(=O)C2(CC(=O)N(C[Al])C2)c2cc(Cl)ccc21</smiles><smiles>CC(C)(C)OC(=O)CN1C(=O)C2(CNC(=O)C2)c2cc(Cl)ccc21</smiles>

40

41

${ }^{a}$ Reagents: (a) Piperidine, nitromethane, r.t., 74\%. (b) $\mathrm{KOH}, \mathrm{MeOH}$, r.t. (c) $\mathrm{HCl}$ (aq), r.t. (d) $\mathrm{DMF}, 160{ }^{\circ} \mathrm{C}$, quant (3 steps). (e) $\mathrm{PdCl} 2$, acetamide, $\mathrm{THF} / \mathrm{H}_{2} \mathrm{O}$. (f) $\mathrm{Zn}, \mathrm{AcOH}$, r.t. to reflux, $54 \%$. (g) $\mathrm{KOtBu}$, THF, then tert-butyl bromoacetate, $0{ }^{\circ} \mathrm{C}$ to r.t., $52 \%$. (h) $\mathrm{NaH}$, $\mathrm{THF}$, then $\mathrm{ArCH} \mathrm{Br}$, r.t., $52 \%$. (i) TFA, DCM, $0{ }^{\circ} \mathrm{C}$ to r.t., $95 \%$.

\section{Scheme $7^{a}$}

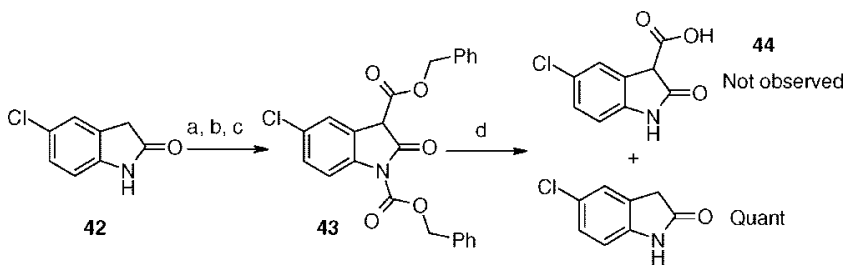

${ }^{a}$ Reagents: (a) Benzylchloroformate, TEA, THF, r.t. (b) DMAP, DMF, r.t. (c) $\mathrm{HCl}, \mathrm{H}_{2} \mathrm{O}$, r.t. (d) $\mathrm{H}_{2}, \mathrm{Pd} / \mathrm{C}$, EtOAc.

furan groups led to a decrease in potency. However, the isoxazole group was found to be a very good replacement. The first derivative prepared $\left(\mathbf{8 5}, K_{\mathrm{i}}=51 \mathrm{nM}\right)$ already showed a potency comparable to that of the thiazole derivative. More importantly, substitution of one of the two methyl groups with a phenyl group led to the discovery of two very active compounds (86, $K_{\mathrm{i}}=7.6 \mathrm{nM}$ and 87, $K_{\mathrm{i}}=5.3 \mathrm{nM}$ ). Interestingly, these two regioisomers showed practically the same potency.

A more limited effort was undertaken for replacement with six-membered heterocycles. Although a pyridine derivative proved to be very potent $\left(\mathbf{8 8}, K_{\mathrm{i}}=12 \mathrm{nM}\right)$, its instability toward oxidative metabolism (see Table 11) discouraged us from further investigations on this type of structures.

The possibility to replace the succinimide moiety was also explored (Table 6). Removal of either of the carbonyl groups gave either of the regioisomeric pyrrolidinones, which showed a very different behavior. Compounds 89-91 retained most of the potency of the corresponding succinimides; $91\left(K_{\mathrm{i}}=3.8\right.$ $\mathrm{nM}$ ) was equipotent to its counterpart 87. In contrast, 92 was found to be very poorly active, clearly suggesting that the carbonyl in the 5-position on the succinimide ring is important to the binding.

Having found a number of active structures, we then moved on to find out whether only one of the two enantiomers was responsible for the activity. The comparison was made for six of the most active racemic compounds (Table 7). Rewardingly, we found that for each couple, one of the two enantiomers showed a much greater affinity for the $\mathrm{CRTH} 2$ receptor than the other, with a 16- to 40-fold difference between them. X-ray analysis of three active enantiomers indicated that the most active enantiomers had the same configuration (Figure 4). All the other absolute structures were assigned by analogy.

The selectivity for three of these highly active, enantiomerically pure compounds was investigated. For a panel of over 50 receptors and enzymes, a more than 100-fold difference in activity was found for $(R)-\mathbf{5 8},(R)-\mathbf{6 0}$, and $(R)$-71. In particular, these compounds were tested against five other prostaglandin receptors (DP, EP2, EP3, EP4, and FP) and in each case were found to have an $\mathrm{IC}_{50}>30 \mu \mathrm{M}$.

The activity of a number of compounds was also tested in a GTP $\gamma$ S binding assay (Table 8). All compounds having a methylenecarboxylic acid substituent on the indolinone nitrogen proved to be antagonists, with activities comparable with those measured in the binding experiment. Some of the most promising compounds were also tested for affinity on the mouse CRTH2 receptor (Table 9). This is of particular importance, because in the field of GPCRs, many examples of receptors showing significant interspecies differences are known, so that a molecule behaving as an effective antagonist on the human receptor could prove to be inactive on the receptors expressed by other species. This, of course, has a high relevance for the feasibility of pharmacological studies in animal models and for the choice of the species for those studies. In our case, the five compounds tested showed a very good correlation between the results obtained on both human and murine CRTH2, indicating that mouse models could be used for in vivo pharmacological evaluation of the compounds.

CRTH2 antagonists were then tested for their ability to inhibit DK-PGD2-induced eosinophil chemotactic activity (Table 10). The effectiveness correlated with potency at CRTH2, thus providing a key indication on the mechanism of action of CRTH2 antagonists in relevant human cells. In addition, CRTH2 


\section{Scheme $\mathbf{8}^{a}$}

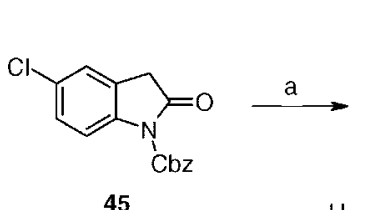

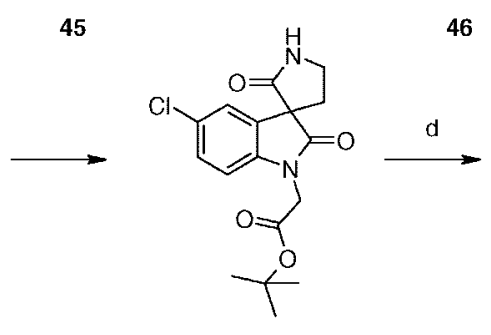

48<smiles>CC1(C)CCCC12CCNC2=O</smiles>

$\mathrm{Cbz}$<smiles>O=C1NCCC12C(=O)Nc1ccc(Cl)cc12</smiles>

47<smiles>CCN1CCC2(C1=O)C(=O)N(CC(=O)O)c1cc(Cl)ccc12</smiles>

50

${ }^{a}$ Reagents: (a) Sodium hydride, DMF, then bromoethylisocyanate, 77\%. (b) $\mathrm{H}_{2}, \mathrm{PtO}_{2}$, DMF, r.t. $95 \%$. (c) $\mathrm{KO} t \mathrm{Bu}$, THF, then tert-butyl bromoacetate, 0 ${ }^{\circ} \mathrm{C}$ to r.t., $30 \%$. (d) $\mathrm{NaH}$, THF, then $\mathrm{ArCH}_{2} \mathrm{Br}$, r.t. (e) TFA, DCM, $0^{\circ} \mathrm{C}$ to r.t.

Table 3. SAR around the Southern Part

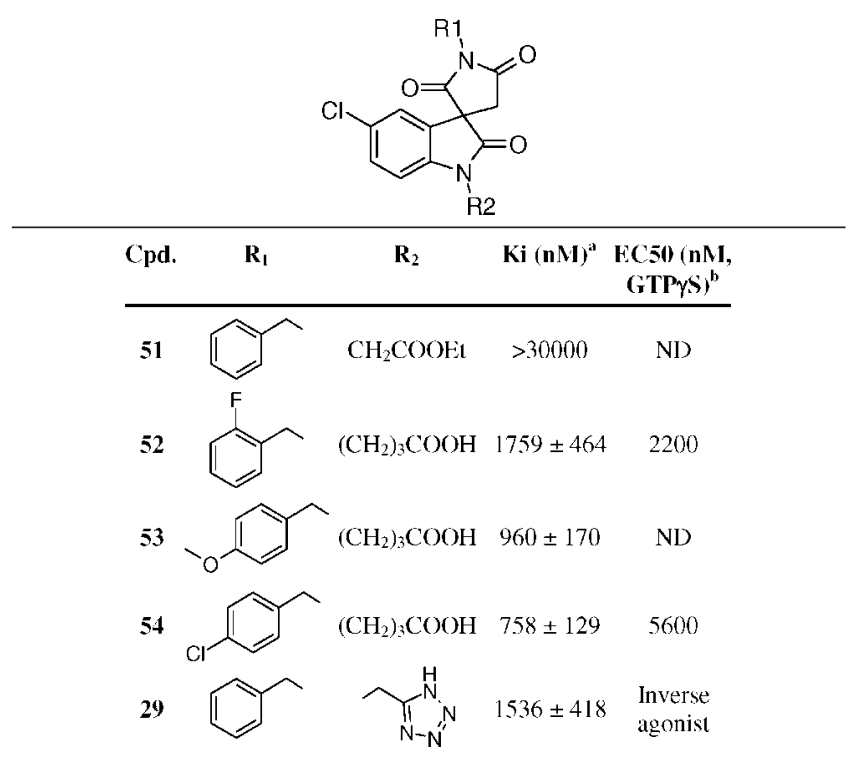

${ }^{a}$ Competitive displacement radioligand binding assay on human CRTH2. ${ }^{b}$ GTP $\gamma \mathrm{S}$ radioligand binding assay.

antagonists did not inhibit eotaxin-induced eosinophil chemotactic activity (data not shown). Finally, no obvious cytotoxic effect could be observed with the concentrations of chemoattractants or the various doses of $\mathrm{CRTH} 2$ antagonists by using the classical MTS assay (data not shown).

In order to select the best compounds for PK studies, the most active compounds were subjected to in vitro profiling, in particular with respect to oxidative metabolism in human and rat liver microsomes and a Caco- 2 cellular permeation model. The results of the microsome stability and Caco- 2 permeability screens are summarized in Table 11.

Most compounds were moderately to highly resistant to oxidative metabolism, demonstrating low intrinsic clearance in both species studied. Notable exceptions were $\mathbf{6 3}$ and $\mathbf{8 8}$, which exhibited high intrinsic clearance ( $>60 \mu \mathrm{L} / \mathrm{min} / \mathrm{mg}$ protein) in the rat liver microsomes; 88 was also the only compound to have high values for the corresponding human microsome experiment. This might be due to oxidative demethylation of the arylmethoxy groups present in these compounds. The molecules did not inhibit five human P450 isoforms (CYP 1A2, $2 \mathrm{C} 19,2 \mathrm{C} 9,2 \mathrm{D} 6$, and $3 \mathrm{~A} 4$ ) up to the maximum concentration tested (10 $\mu \mathrm{M})$. There was one exception; only $(R)$-71 showed some inhibition on one isoform with an estimated $\mathrm{IC}_{50} \approx 5.3$ $\mu \mathrm{M}$ on CYP 2C19. Overall, the series demonstrated a low potential for P450-mediated drug-drug interaction.

In contrast, more problems were encountered with regard to the in vitro permeability of these compounds. This was not entirely surprising, considering both the structures of the compounds, which have a carboxylic acid, the negative effect on permeability of which is well-known, and the data obtained for the hit compound 5. In most cases, the Papp observed in the Caco- 2 experiments varied between $0.8 \times 10^{-6}$ and $2.4 \times$ $10^{-6} \mathrm{~cm} \cdot \mathrm{s}^{-1}$ (low permeability range in our assay). The notable exception was $(R)-\mathbf{7 1}$, for which the increase of lipophilicity on the phenyl substituent led to a substantial improvement on the in vitro permeability (Papp $26.4 \times 10^{-6} \mathrm{~cm} \cdot \mathrm{s}^{-1}$, high permeability range).

On the basis of the data gathered, four compounds were selected for PK studies in rat. The results are summarized in Table 12. Both succinimide compounds $(R)-\mathbf{5 8}$ and $(R)-\mathbf{7 1}$ showed moderate and very similar clearance and oral bioavailability values. Although the clearance was in line with the values predicted by the results of the in vitro rat liver microsome experiment, the similar oral bioavailability of both compounds was unexpected when incorporating the results of the Caco-2 experiments. Because of the high permeability ranking of $(R)$ 71 (with equivalent clearance), we expected this compound to have an oral bioavailability higher than that of $(R)-\mathbf{5 8}$. $(R)-\mathbf{7 1}$ displayed a much higher volume of distribution than that of $(R)-58(\mathrm{Vss}=7 \mathrm{~L} / \mathrm{kg}$ for $(R)-71 \mathrm{vs} \mathrm{Vss}=0.9 \mathrm{~L} / \mathrm{kg}$ for $(R)-$ 58), indicating that whereas the latter compound appears to remain in the central plasma compartment (Vss $\approx$ total body water), the former appears to be distributing into some tissues, possibly because of its higher lipophilicity. This observation was confirmed in the PK studies in $\operatorname{dog}\left(\mathrm{Vss}_{\mathrm{ss}}=2 \mathrm{~L} / \mathrm{kg}\right.$ for $(R)$ 58 vs Vss $=5 \mathrm{~L} / \mathrm{kg}$ for $(R)-71)$. For both compounds, oral bioavailability was moderate to high in this species; however, in contrast to rats, $(R)-\mathbf{5 8}$ showed a lower clearance (approximatively $20 \%$ of liver blood flow) and higher oral bioavailability than $(R)-71$ in dogs. The reason for this was not investigated.

As for the pyrrolidinone compounds, both molecules tested gave much poorer results in vivo in rat than what could be expected on the basis of the data obtained in in vitro metabolic tests, both compounds not being metabolized at all in the presence of rat liver microsomes. For 91, the very high clearance observed after intravenous dosing $\left(\mathrm{Cl} \approx\right.$ liver blood flow, $\left.Q_{\mathrm{H}}\right)$ 

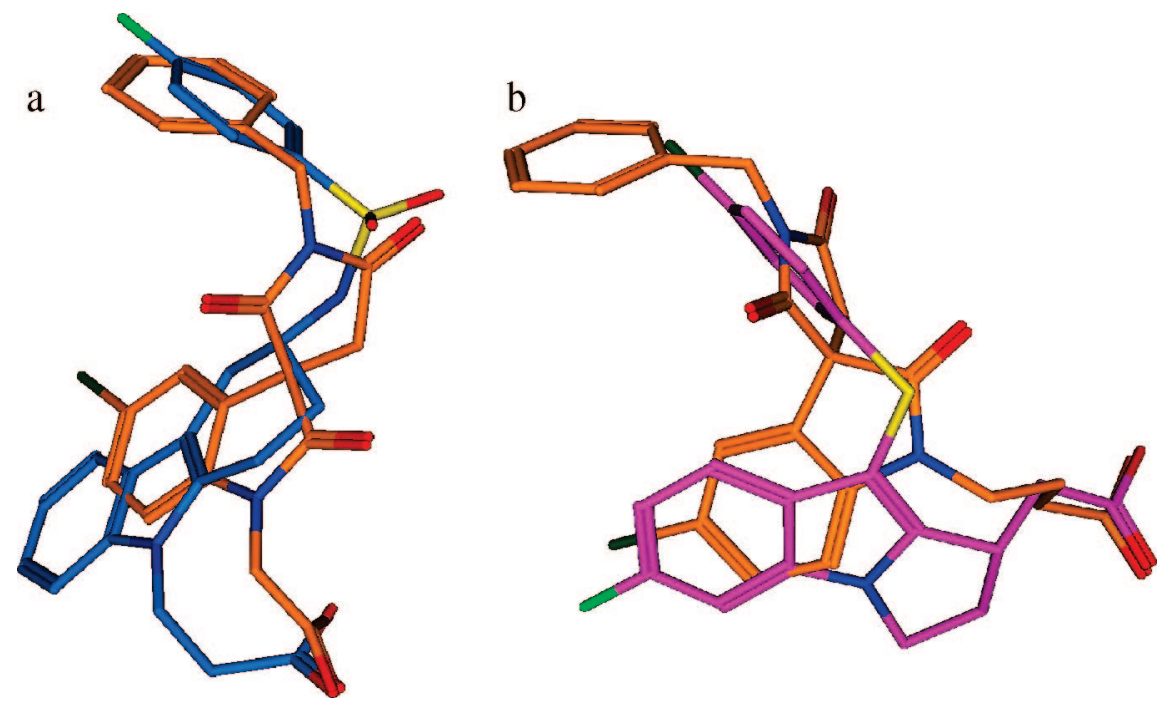

Figure 3. (a) Overlay of $\mathbf{5}$ (R enantiomer) with ramatroban. (b) Overlay of the three-carbon chain analogue of $\mathbf{5}$ (R enantiomer) with the CRTH2 agonist L-888,607. ${ }^{19}$

Table 4. SAR around the Northern Part (1)

(1)

${ }^{a}$ Competitive displacement radioligand binding assay on human CRTH2.

highlighted the possibility of an extra-hepatic route of clearance and/or phase 2 metabolism, which was however unconfirmed. For $(S)-90$, the clearance value was higher than the value that would be predicted on the basis of the liver microsomes experiments alone, albeit acceptable and similar to that of the succinimide compounds (low to medium, $\mathrm{Cl} \approx 20 \% Q_{\mathrm{H}}$ ). For this molecule, the very low oral bioavailability could probably be better explained by poor and prolonged absorption, especially considering that a concentration plateau was observed between 0.25 and $2 \mathrm{~h}$ after oral dosing, as well as by the fact that $t 1 / 2$ per oral route was found to be significantly longer than t1/2 per IV ( 7.9 vs $0.9 \mathrm{~h}$ ), indicating that it was not the elimination phase that was observed but rather a mixture of absorption-elimination.

The relatively poor correlation of the in vitro-in vivo behavior we observed with the compounds in this chemical series highlights the importance of conducting in vivo PK studies early in the lead optimization stage. With this knowledge, we could customize the in vitro ADME screening cascade for better predictive ability before launching into the labor-intensive full lead optimization effort and further in vivo testing.

\section{Conclusion}

We have identified a novel family of CRTH2 antagonists. The initial hit 5, having a $K_{\mathrm{i}}$ of $196 \mathrm{nM}$, was optimized, and molecules with $K_{\mathrm{i}}$ in the low single-digit nanomolar range were discovered. The potency of these compounds was confirmed in a human eosinophil chemotaxis experiment. The compounds were characterized in terms of pharmaco-kinetic properties both in vitro and in vivo, and two molecules $((R)-58$ and $(R)-71)$ having suitable characteristics for further pharmacological evaluation in vivo were identified.

\section{Experimental Section}

All chemicals were purchased from Fluka-Aldrich (Buchs, Switzerland) unless otherwise stated. Melting points were measured with a Büchi Melting Point B-545 apparatus and were uncorrected. NMR spectra were recorded on a Bruker DPX-300 MHz spectrometer. Data were reported as follows: chemical shift in ppm by using either residual dimethyl sulfoxide (DMSO, $2.49 \mathrm{ppm}$ ), $\mathrm{CHCl}_{3}$ (7.24 ppm), or $\mathrm{MeOH}$ (3.35 ppm) as internal standards on the scale, multiplicity (s, singlet; br s, broad singlet; d, doublet; t, triplet; q, quadruplet; and m, multiplet), coupling constants $(J)$ in hertz, and integration. MS data provided were obtained by using a Waters ZMD mass spectrometer operated in positive or negative electrospray. Analytical HPLC method A: Xterra MSC8, $50 \times 4.6 \mathrm{~mm}$, $3.5 \mu \mathrm{m}, 0.1 \%$ TFA in $\mathrm{H}_{2} \mathrm{O}$ (solvent A), $0.1 \%$ TFA in $\mathrm{MeCN}$ (solvent B), linear gradient $5 \%$ to $100 \%$ B (8 min, flow rate $2 \mathrm{~mL} /$ min), UV detection Max Plot 230-400 nm. Chiral HPLC method 
Table 5. SAR around the Northern Part (2): Heteroaromatics

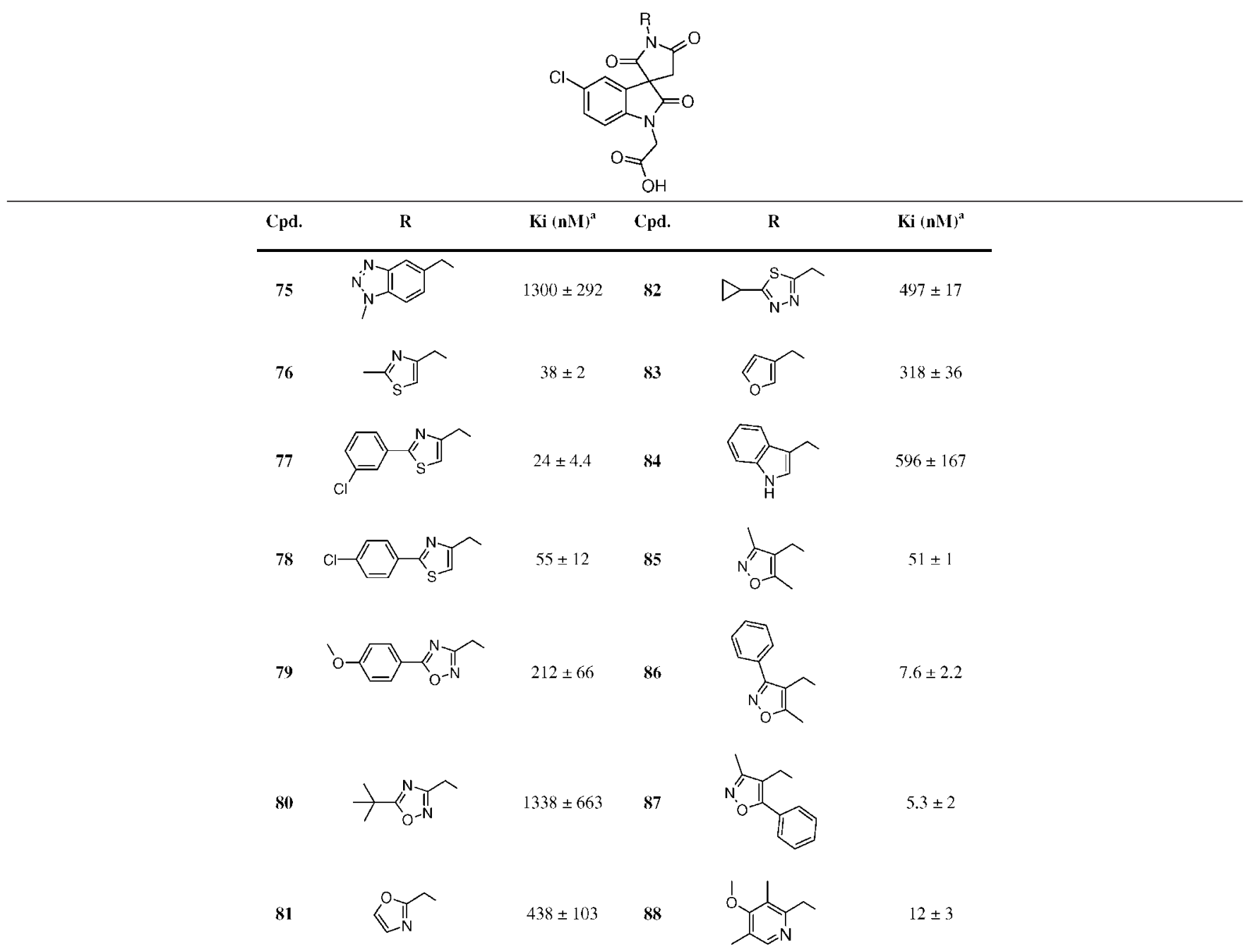

${ }^{a}$ Competitive displacement radioligand binding assay on human CRTH2.

A: Chiralpak AD-H (Daicel) $250 \times 4.6 \mathrm{~mm}$ column, isocratic conditions ethanol:formic acid 100:0.1 (v/v) (30 min, flow rate 1 $\mathrm{mL} / \mathrm{min}$, column temperature $30^{\circ} \mathrm{C}$ ), UV detection $254 \mathrm{~nm}$. Chiral HPLC method B: Chiralcel OJ-H (Daicel) $250 \times 4.6 \mathrm{~mm}$ column, isocratic conditions methanol:formic acid 100:0.1 (v/v) $(20 \mathrm{~min}$, flow rate $1 \mathrm{~mL} / \mathrm{min}$, column temperature $40{ }^{\circ} \mathrm{C}$ ), UV detection 254 $\mathrm{nm}$. Elemental analyses were performed on an Erba Science 11108 $\mathrm{CHN}$ analyzer.

Methyl (5-Chloro-2-oxo-1,2-dihydro-3H-indol-3-ylidene)(cyano)acetate (20). A stirred mixture of 5-chloro- $1 H$-indole-2,3-dione $(90.8 \mathrm{~g}, 0.500 \mathrm{~mol})$ and methyl cyanoacetate $(44.1 \mathrm{~mL}, 0.500 \mathrm{~mol})$ in methanol $(1000 \mathrm{~mL})$ was treated with piperidine $(2 \mathrm{~mL})$ and heated under reflux for $5 \mathrm{~h}$ before standing overnight at ambient temperature. The crude (5-chloro-2-oxo-1,2-dihydro-indol-3-ylidene)cyanoacetic acid methyl ester was removed by filtration, washed with cold methanol $(2 \times 150 \mathrm{~mL})$, and dried in vacuo to give 117.6 $\mathrm{g}(90 \%)$ of a dark purple solid (6.5:1 mixture of geometric isomers) which was sufficiently pure by ${ }^{1} \mathrm{H}$ NMR for subsequent reaction. ${ }^{1} \mathrm{H}$ NMR (300 MHz, DMSO-d $\left.\mathrm{d}_{6}\right) \delta 11.22$ and $11.11(1 \mathrm{H}, 2 \mathrm{br} \mathrm{s})$, 8.27 and $7.78(1 \mathrm{H}, 2 \mathrm{br} \mathrm{s}), 7.55$ and $7.42(1 \mathrm{H}, 2 \mathrm{~m}), 6.91(1 \mathrm{H}, \mathrm{m})$, 3.95 and $3.88(3 \mathrm{H}, 2 \mathrm{~s})$.

(5-Chloro-3-cyano-2-oxo-2,3-dihydro-1 $\mathrm{H}$-indol-3-yl)-cyanoacetic Acid Methyl Ester (21). A stirred suspension of crude (5-chloro2-oxo-1,2-dihydro-indol-3-ylidene)-cyanoacetic acid methyl ester $20(56.0 \mathrm{~g}, 0.210 \mathrm{~mol})$ in methanol $(750 \mathrm{~mL})$ was treated, in portions, with potassium cyanide $(13.8 \mathrm{~g}, 0.210 \mathrm{~mol})$ and then with water $(45 \mathrm{~mL})$. The mixture was stirred at ambient temperature for $7 \mathrm{~h}$, and the resultant black solution was left to stand overnight. The solvent was removed in vacuo, water $(500 \mathrm{~mL})$ was added, and the mixture was acidified by the addition of $2 \mathrm{M}$ hydrochloric acid. [Caution: Traces of cyanide may still be present!] The mixture was extracted with dichloromethane $(3 \times 300 \mathrm{~mL})$. The combined extracts were washed with water $(2 \times 300 \mathrm{~mL})$ and dried $\left(\mathrm{MgSO}_{4}\right)$. The solvent was removed in vacuo to give the crude (5-chloro-3cyano-2-oxo-2,3-dihydro- $1 H$-indol-3-yl)-cyanoacetic acid methyl ester as a pale-brown solid (53.3 g, 86\%). ${ }^{1} \mathrm{H}$ NMR $(300 \mathrm{MHz}$, DMSO- $\left.\mathrm{d}_{6}\right) \delta 11.7$ and $11.69(1 \mathrm{H}, 2 \mathrm{~s}), 7.70$ and $7.76(1 \mathrm{H}, 2 \mathrm{~m})$, 7.52 and $7.49(1 \mathrm{H}, 2 \mathrm{~m}), 7.04$ and $7.02(1 \mathrm{H}, 2 \mathrm{~m}), 5.92$ and 5.83 $(1 \mathrm{H}, 2 \mathrm{~s}), 3.74(3 \mathrm{H}, \mathrm{s})$.

5-Chloro-1H-spiro[indole-3,3'-pyrrolidine]-2,2',5'-trione (22). A stirred solution of the crude (5-chloro-3-cyano-2-oxo-2,3-dihydro$1 H$-indol-3-y)-cyanoacetic acid methyl ester 21 (53.3 g, $0.180 \mathrm{~mol}$ ) in methanol $(450 \mathrm{~mL})$ was cooled in an ice-water bath and saturated with hydrogen chloride gas, keeping the temperature below $20{ }^{\circ} \mathrm{C}$. The resultant solution was left to stand at ambient temperature overnight and then heated cautiously under reflux for $5 \mathrm{~h}$ to give a yellow suspension. The solvent was removed in vacuo to give a semi-solid residue that was mixed with glacial acetic acid $(375 \mathrm{~mL})$ and heated under reflux, with stirring, for $16 \mathrm{~h}$. After cooling in an ice-water bath, the crude 5-chloro- $1 \mathrm{H}$-spiro[indole$3,3^{\prime}$-pyrrolidine]-2,2',5'-trione was removed by filtration, washed with cold glacial acetic acid $(100 \mathrm{~mL})$, then with water $(100 \mathrm{~mL})$, and then diethyl ether $(100 \mathrm{~mL})$, and dried in vacuo to give an off-white solid. A second crop was obtained by removing the 
Table 6. Modifications of Succinimide Core

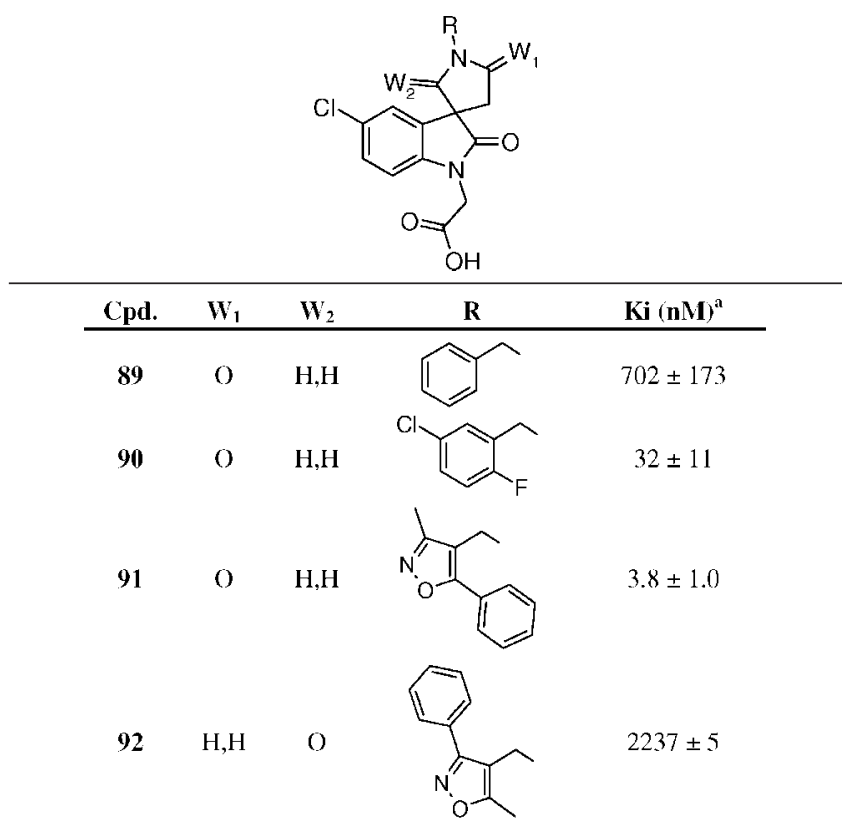

${ }^{a}$ Competitive displacement radioligand binding assay on human CRTH2.

Table 7. Activity of Pure Enantiomers

\begin{tabular}{cc}
\hline compound & $K_{\mathrm{i}}(\mathrm{nM})^{a}$ \\
\hline$(R)-\mathbf{5}$ & $81 \pm 41$ \\
$(S)-\mathbf{5}$ & $2044 \pm 16$ \\
$(R)-\mathbf{5 8}$ & $23 \pm 11$ \\
$(S)-\mathbf{5 8}$ & $926 \pm 400$ \\
$(R)-\mathbf{6 0}$ & $23 \pm 8$ \\
$(S)-\mathbf{6 0}$ & $870 \pm 129$ \\
$(R)-\mathbf{6 3}$ & $72 \pm 13$ \\
$(S)-\mathbf{6 3}$ & $1172 \pm 182$ \\
$(S)-\mathbf{7 1}$ & $302 \pm 56$ \\
$(R)-\mathbf{7 1}$ & $5.3 \pm 1.1$ \\
$(S)-\mathbf{9 0}$ & $13 \pm 2$ \\
$(R)-\mathbf{9 0}$ & $683 \pm 74$ \\
\hline
\end{tabular}

${ }^{a}$ Competitive displacement radioligand binding assay on human CRTH2.

solvent in vacuo from the combined acetic acid filtrates and repeating the purification procedure to give a total of $30.5 \mathrm{~g}(66 \%)$. ${ }^{1} \mathrm{H}$ NMR (300 MHz, DMSO-d $\left.\mathrm{d}_{6}\right) \delta 11.8$ (1H, br s), 10.9 (1H, br s), $7.69(1 \mathrm{H}, \mathrm{d}, J=2.0 \mathrm{~Hz}), 7.32(1 \mathrm{H}, \mathrm{dd}, J=8.5 \mathrm{~Hz} ; J=2.0 \mathrm{~Hz})$, $6.89(1 \mathrm{H}, \mathrm{d}, J=8.5 \mathrm{~Hz}), 3.16(1 \mathrm{H}, \mathrm{d}, J=18.0 \mathrm{~Hz}), 2.95(1 \mathrm{H}, \mathrm{d}$, $J=18.0 \mathrm{~Hz})$. MS: $249.1[\mathrm{M}-\mathrm{H}]^{-}$.

1'-Benzyl-5-chloro-1H-spiro[indole-3,3'-pyrrolidine]-2,2',5'trione (23). A stirred solution of 5-chloro- $1 H$-spiro[indole-3,3'pyrrolidine]-2,2',5'-trione $22(800 \mathrm{mg}, 3.19 \mathrm{mmol})$ in anhydrous $N, N$-dimethylformamide $(6 \mathrm{~mL})$ was treated with potassium tertbutoxide (377 mg, $3.19 \mathrm{mmol}$ ). After stirring at ambient temperature for $40 \mathrm{~min}$, benzyl bromide $(0.38 \mathrm{~mL}, 3.19 \mathrm{mmol})$ was added. The mixture was stirred for $2 \mathrm{~h}$ and left to stand overnight. The resultant mixture was diluted with water $(50 \mathrm{~mL})$ and extracted with ethyl acetate $(3 \times 50 \mathrm{~mL})$. The combined extracts were dried $\left(\mathrm{MgSO}_{4}\right)$, and the solvent was removed in vacuo to give the crude $1^{\prime}$-benzyl5-chloro- $1 H$-spiro[indole-3,3'-pyrrolidine]-2,2',5'-trione, which was purified by flash chromatography (silica) eluting with petroleum ether (40-60) containing an increasing amount (0 to 75\%) of ethyl acetate. This gave $789 \mathrm{mg}(73 \%)$ of the title compound as a yellow solid. ${ }^{1} \mathrm{H}$ NMR $\left(300 \mathrm{MHz}, \mathrm{DMSO}-\mathrm{d}_{6}\right) \delta 11.01(1 \mathrm{H}, \mathrm{s}), 7.68(1 \mathrm{H}$, $\mathrm{d}, J=2.0 \mathrm{~Hz}), 7.37-7.25(6 \mathrm{H}, \mathrm{m}), 6.92(1 \mathrm{H}, \mathrm{d}, J=8.5 \mathrm{~Hz}), 4.68$ $(1 \mathrm{H}, \mathrm{d}, J=15.5 \mathrm{~Hz}), 4.63(1 \mathrm{H}, \mathrm{d}, J=15.5 \mathrm{~Hz}), 3.31(1 \mathrm{H}, \mathrm{d}, J=$ $18.0 \mathrm{~Hz}), 3.14(1 \mathrm{H}, \mathrm{d}, J=18.0 \mathrm{~Hz})$. MS: $341.3[\mathrm{M}+\mathrm{H}]^{+} ; 339.2$ $[\mathrm{M}-\mathrm{H}]^{-}$.
(1'-Benzyl-5-chloro-2,2',5'-trioxo-spiro[indole-3,3'-pyrrolidin]1-yl)-acetic Acid tert-Butyl Ester (24). A stirred suspension of sodium hydride $(60 \%$ dispersion in oil [116 mg, $2.90 \mathrm{mmol}])$ in anhydrous tetrahydrofuran $(30 \mathrm{~mL})$ was treated with $1^{\prime}$-benzyl-5chloro- $1 H$-spiro[indole-3,3'-pyrrolidine]-2,2',5'-trione 23 (900 mg, $2.64 \mathrm{mmol}$ ). After being stirred at ambient temperature for $30 \mathrm{~min}$, the clear solution was treated with tert-butyl bromoacetate $(0.51$ $\mathrm{mL}, 3.4 \mathrm{mmol}$ ). The resultant suspension was stirred for $3 \mathrm{~h}$ and then left to stand overnight. Water $(100 \mathrm{~mL})$ was added, and the mixture extracted with ethyl acetate $(3 \times 100 \mathrm{~mL})$. The combined extracts were washed with brine $(100 \mathrm{~mL})$ and dried $\left(\mathrm{MgSO}_{4}\right)$, and the solvent was removed in vacuo to give the crude (1'-benzyl-5chloro-2,2',5'-trioxo-spiro[indole-3,3'-pyrrolidin]-1-yl)-acetic acid tert-butyl ester. This was purified by flash chromatography (silica) eluting with petroleum ether $(40-60)$ containing an increasing amount ( 0 to $50 \%)$ of ethyl acetate to give the title compound as a white solid $(1.088 \mathrm{~g}, 91 \%) .{ }^{1} \mathrm{H}$ NMR $\left(300 \mathrm{MHz}, \mathrm{DMSO}-\mathrm{d}_{6}\right) \delta$ $7.80(1 \mathrm{H}, \mathrm{d}, J=2.0 \mathrm{~Hz}), 7.47(1 \mathrm{H}, \mathrm{dd}, J=8.5 \mathrm{~Hz} ; J=2.0 \mathrm{~Hz})$, $7.37-7.27(5 \mathrm{H}, \mathrm{m}), 7.13(1 \mathrm{H}, \mathrm{d}, J=8.5 \mathrm{~Hz}), 4.71(1 \mathrm{H}, \mathrm{d}, J=$ $15.5 \mathrm{~Hz}), 4.65(1 \mathrm{H}, \mathrm{d}, J=15.5 \mathrm{~Hz}), 4.53(1 \mathrm{H}, \mathrm{d}, J=18.0 \mathrm{~Hz})$, $4.48(1 \mathrm{H}, \mathrm{d}, J=18.0 \mathrm{~Hz}), 3.41(1 \mathrm{H}, \mathrm{d}, J=18.0 \mathrm{~Hz}), 3.10(1 \mathrm{H}, \mathrm{d}$, $J=18.0 \mathrm{~Hz}), 1.38(9 \mathrm{H}, \mathrm{s})$. MS: $399.3[\mathrm{M}-\mathrm{H}-t \mathrm{Bu}]^{+} ; 453.4[\mathrm{M}$ $-\mathrm{H}]^{-}$.

(1'-Benzyl-5-chloro-2,2' ,5'-trioxo-spiro[indole-3,3'-pyrrolidin]1-yl)acetic Acid (5). A stirred solution of (1'-benzyl-5-chloro2,2',5'-trioxo-spiro[indole-3,3'-pyrrolidin]-1-yl)-acetic acid tert-butyl ester $24(800 \mathrm{mg}, 1.76 \mathrm{mmol})$ in anhydrous dichloromethane $(20$ $\mathrm{mL}$ ) was cooled in an ice-water bath and treated with trifluoroacetic acid $(2.0 \mathrm{~mL})$. After being stirred in the cold for $30 \mathrm{~min}$, the mixture was allowed to reach ambient temperature, and the reaction mixture was stirred at ambient temperature for $48 \mathrm{~h}$. The solvent was removed in vacuo, and toluene $(50 \mathrm{~mL})$ was added. The crude $\left(1^{\prime}-\right.$ benzyl-5-chloro-2,2',5'-trioxo-spiro[indole-3,3'-pyrrolidin]-1-yl)acetic acid was removed by filtration and washed with more toluene $(25 \mathrm{~mL})$ and then with petroleum ether $(25 \mathrm{~mL})$. Purification by flash chromatography (silica) eluting with ethyl acetate gave a white solid (401 mg, 57\%), mp 205-207 ${ }^{\circ} \mathrm{C} .{ }^{1} \mathrm{H} \mathrm{NMR}(300 \mathrm{MHz}$, DMSO-d $\left._{6}\right) \delta 13.2(1 \mathrm{H}$, br s $), 7.79(1 \mathrm{H}, \mathrm{d}, J=2.0 \mathrm{~Hz}), 7.46(1 \mathrm{H}$, $\mathrm{dd}, J=8.5 \mathrm{~Hz} ; J=2.0 \mathrm{~Hz}), 7.38-7.26(5 \mathrm{H}, \mathrm{m}), 7.16(1 \mathrm{H}, \mathrm{d}, J=$ $8.5 \mathrm{~Hz}), 4.77(1 \mathrm{H}, \mathrm{d}, J=15.5 \mathrm{~Hz}), 4.65(1 \mathrm{H}, \mathrm{d}, J=15.5 \mathrm{~Hz})$, $4.55(1 \mathrm{H}, \mathrm{d}, J=18.0 \mathrm{~Hz}), 4.47(1 \mathrm{H}, \mathrm{d}, J=18.0 \mathrm{~Hz}), 3.41(1 \mathrm{H}, \mathrm{d}$, $J=18.0 \mathrm{~Hz}), 3.10(1 \mathrm{H}, \mathrm{d}, J=18.0 \mathrm{~Hz}) . \mathrm{MS}: 399.1[\mathrm{M}-\mathrm{H}]^{+}$; $397.1[\mathrm{M}-\mathrm{H}]^{-}$. Anal. $\left(\mathrm{C}_{20} \mathrm{H}_{15} \mathrm{ClN}_{2} \mathrm{O}_{5}\right) \mathrm{C}, \mathrm{H}, \mathrm{N}$.

$1^{\prime}$-benzyl-5-chloro-1-(1H-tetrazol-5-ylmethyl)-2' $H, 5^{\prime} H$-spiro[indole-3,3'-pyrrolidine]-2,2',5'(1H)-trione (29). A stirred suspension of sodium hydride ( $60 \%$ dispersion in oil [29 $\mathrm{mg}, 0.73 \mathrm{mmol}]$ ) in anhydrous tetrahydrofuran $(8.0 \mathrm{~mL})$ was treated with 1'-benzyl-5chloro- $1 H$-spiro[indole-3,3'-pyrrolidine]-2,2', 5'-trione 23 (225 mg, $0.66 \mathrm{mmol}$ ). After being stirred at ambient temperature for $30 \mathrm{~min}$, the clear solution was treated with bromoacetonitrile $(0.060 \mathrm{~mL}$, $0.86 \mathrm{mmol})$. The resultant suspension was stirred overnight. Water $(50 \mathrm{~mL})$ was added, and the mixture extracted with ethyl acetate $(3 \times 50 \mathrm{~mL})$. The combined extracts were washed with brine $(50$ $\mathrm{mL})$ and dried $\left(\mathrm{MgSO}_{4}\right)$, and the solvent was removed in vacuo to give the crude intermediate, which was purified by flash chromatography (silica) eluting with petroleum ether (40-60) containing an increasing amount ( 0 to $50 \%)$ of ethyl acetate. The purified intermediate $(115 \mathrm{mg}, 0.303 \mathrm{mmol})$ in anhydrous DMF $(2.3 \mathrm{~mL})$ was treated with sodium azide $(29 \mathrm{mg}, 0.45 \mathrm{mmol})$ and with ammonium chloride ( $25 \mathrm{mg}, 0.45 \mathrm{mmol}$ ). The reaction mixture was heated at $125^{\circ} \mathrm{C}$ for $2 \mathrm{~h}$ before cooling to room temperature. Water was added, and the mixture was extracted with ethyl acetate. The combined organic phases were washed with brine and dried $\left(\mathrm{MgSO}_{4}\right)$, and the solvent was removed in vacuo to give the crude 1'-benzyl-5-chloro-1-(1H-tetrazol-5-ylmethyl)-2' $H, 5^{\prime} H$-spiro[indole$3,3^{\prime}$-pyrrolidine]-2, $2^{\prime}, 5^{\prime}(1 H)$-trione, which was purified by recrystallization from chloroform to give a white solid (71 mg, 25\%). ${ }^{1} \mathrm{H}$ NMR (300 MHz, DMSO-d $\left.\mathrm{d}_{6}\right) \delta 7.82(1 \mathrm{H}, \mathrm{d}, J=2.0 \mathrm{~Hz}), 7.47$ $(1 \mathrm{H}, \mathrm{dd}, J=8.5 \mathrm{~Hz} ; J=2.0 \mathrm{~Hz}), 7.38-7.26(5 \mathrm{H}, \mathrm{m}), 7.16(1 \mathrm{H}$, $\mathrm{d}, J=8.5 \mathrm{~Hz}), 5.35(1 \mathrm{H}, \mathrm{d}, J=16.5 \mathrm{~Hz}), 5.30(1 \mathrm{H}, \mathrm{d}, J=16.5$ $\mathrm{Hz}), 4.71(1 \mathrm{H}, \mathrm{d}, J=15.5 \mathrm{~Hz}), 4.66(1 \mathrm{H}, \mathrm{d}, J=15.5 \mathrm{~Hz}), 3.41$ 


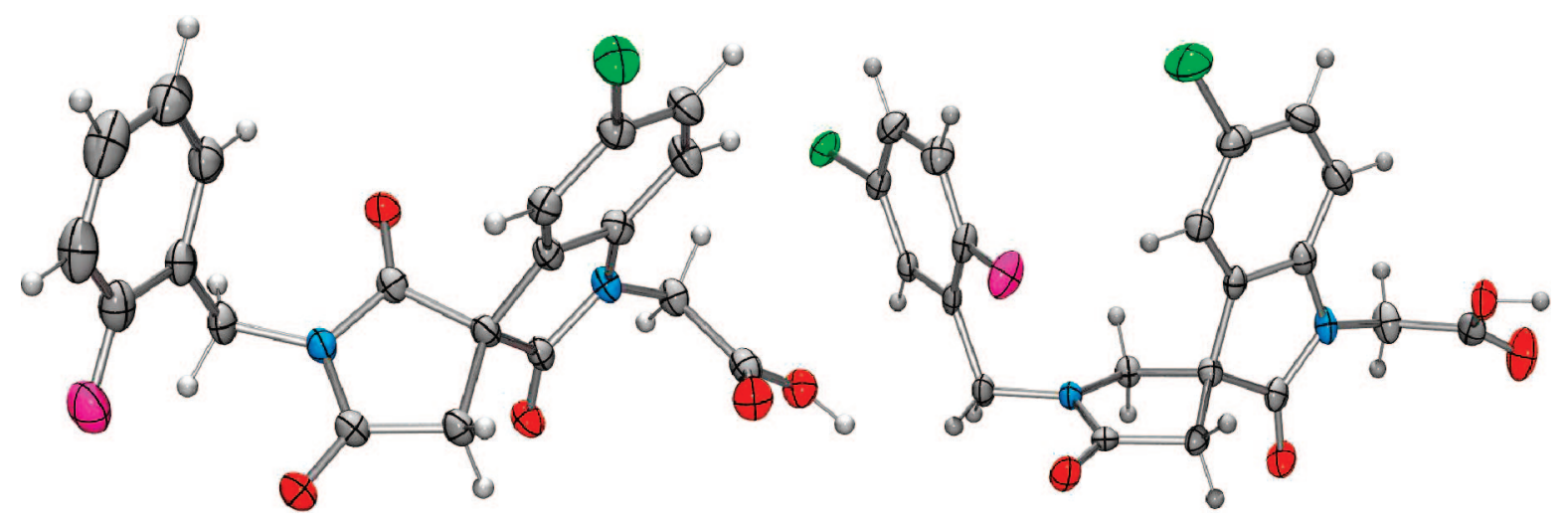

Figure 4. X-ray structure of (R)-58 (left) and ( $S)$-90 (right).

Table 8. Activity in the GTP $\gamma$ S Assay

\begin{tabular}{cc}
\hline compound & $\mathrm{IC}_{50}(\mathrm{nM})^{a}$ \\
\hline $\mathbf{5 8}$ & $212 \pm 26$ \\
$\mathbf{5 9}$ & $182 \pm 18$ \\
$\mathbf{6 0}$ & $122 \pm 28$ \\
$\mathbf{6 6}$ & $296 \pm 104$ \\
$\mathbf{7 1}$ & $48 \pm 0.1$ \\
$\mathbf{7 2}$ & $82 \pm 5$ \\
$\mathbf{7 6}$ & $236 \pm 8$ \\
$\mathbf{7 7}$ & $48 \pm 15$ \\
$\mathbf{8 5}$ & $220 \pm 23$ \\
$\mathbf{8 6}$ & $21 \pm 12$ \\
$\mathbf{8 7}$ & $23 \pm 10$ \\
$\mathbf{9 1}$ & $19 \pm 2$ \\
$(R)-\mathbf{6 0}$ & $107 \pm 6$ \\
$(R)-\mathbf{7 1}$ & $66 \pm 8$
\end{tabular}

${ }^{a} \mathrm{GTP} \gamma \mathrm{S}$ radioligand binding assay on human $\mathrm{CRTH} 2$.

Table 9. Activity on Human and Murine CRTH2

\begin{tabular}{lcc}
\hline compound & $K_{\mathrm{i}}(\mathrm{hCRTH} 2, \mathrm{nM})^{a}$ & $K_{\mathrm{i}}(\mathrm{mCRTH} 2, \mathrm{nM})^{b}$ \\
\hline $\mathbf{5}$ & $196 \pm 124$ & 150 \\
$\mathbf{8 9}$ & $702 \pm 173$ & 480 \\
$(R)-\mathbf{5 8}$ & $23 \pm 11$ & 22 \\
$(R)-\mathbf{6 0}$ & $23 \pm 8$ & 33 \\
$(R)-\mathbf{7 1}$ & $5.3 \pm 1.1$ & 5 \\
$(S)-\mathbf{9 0}$ & $13 \pm 2$ & 88 \\
\hline
\end{tabular}

${ }^{a}$ Competitive displacement radioligand binding assay on human CRTH2.

${ }^{b}$ Competitive displacement radioligand binding assay on murine CRTH2.

Table 10. Inhibition of Human Eosinophil Chemotaxis Induced by DK-PGD2 2

\begin{tabular}{lc}
\hline compound & IC50 $(\mathrm{nM})$ \\
\hline $\mathbf{3}$ & $169 \pm 79$ \\
$\mathbf{5}$ & $156 \pm 90$ \\
$(R)-\mathbf{5}$ & $104 \pm 72$ \\
$(R)-\mathbf{5 8}$ & $40 \pm 30$ \\
$(R)-\mathbf{6 0}$ & $76 \pm 39$ \\
$(R)-\mathbf{6 3}$ & $18 \pm 9$ \\
$\mathbf{7 1}$ & $24 \pm 11$ \\
$(R)-\mathbf{7 1}$ & $7.3 \pm 4.2$ \\
$\mathbf{8 9}$ & $1350 \pm 276$ \\
$\mathbf{9 0}$ & $97 \pm 33$ \\
$(S)-\mathbf{9 0}$ & $62 \pm 36$ \\
$\mathbf{9 1}$ & $0.23 \pm 0.16$ \\
\hline
\end{tabular}

$(1 \mathrm{H}, \mathrm{d}, J=18.0 \mathrm{~Hz}), 3.19(1 \mathrm{H}, \mathrm{d}, J=18.0 \mathrm{~Hz}) . \mathrm{MS}: 423.0[\mathrm{M}-$ $\mathrm{H}]^{+} ; 421.0[\mathrm{M}-\mathrm{H}]^{-}$.

(5-Chloro-2,2', $5^{\prime}$-trioxospiro[indole-3,3'-pyrrolidin]-1-yl)acetic Acid tert-Butyl Ester (30). To a stirred suspension of sodium hydride (60\% dispersion in mineral oil, $1.68 \mathrm{~g}, 42.0 \mathrm{mmol}$ ) in anhydrous $N, N$-dimethylformamide $(140 \mathrm{~mL})$ was added $22(5.00$ $\mathrm{g}, 20.0 \mathrm{mmol}$ ). After being stirred at ambient temperature for 40 min, the dark orange solution was cooled in an ice bath and treated for $30 \mathrm{~min}$ with a solution of tert-butyl bromoacetate $(3.24 \mathrm{~g}, 2.26$
Table 11. In Vitro ADME Characterization of Selected Compounds

\begin{tabular}{|c|c|c|c|c|}
\hline compound & $\begin{array}{c}\mathrm{Cl}(\mathrm{h}-\mathrm{LM}, \mu \mathrm{L} / \\
\mathrm{min} / \mathrm{mg} \text { protein })^{a}\end{array}$ & $\begin{array}{c}\mathrm{Cl}(\mathrm{r}-\mathrm{LM}, \mu \mathrm{L} / \\
\mathrm{min} / \mathrm{mg} \text { protein })^{a}\end{array}$ & $\begin{array}{c}\text { Caco-2 } \\
\left(\text { Papp, } 10^{-6} \mathrm{~cm} / \mathrm{s}\right)^{b}\end{array}$ & ${ }^{b} \log D$ \\
\hline$(R)-58$ & 15 & 23 & 2.4 & -1 \\
\hline$(R)-60$ & 3 & 8 & ND & -0.4 \\
\hline$(R)-63$ & 9 & 68 & 0.8 & ND \\
\hline 67 & 6 & 0 & ND & -0.9 \\
\hline 68 & 4 & 0 & ND & -0.9 \\
\hline 69 & 3 & 31 & ND & -0.7 \\
\hline 70 & 2 & 24 & ND & -0.3 \\
\hline$(R)-71$ & 5 & 19 & 26.4 & -0.5 \\
\hline 73 & 10 & 8 & ND & -0.2 \\
\hline 86 & 0 & 26 & ND & -0.6 \\
\hline 88 & 71 & 66 & 0 & ND \\
\hline$(S)-90$ & 3 & 0 & 1.8 & -0.4 \\
\hline 91 & 0 & 0 & 2.1 & -0.3 \\
\hline
\end{tabular}

${ }^{a}$ Microsome stability experiment. h-LM, human liver microsomes; r-LM, rat liver microsomes. ${ }^{b}$ Caco-2 cell permeability assay.

$\mathrm{mL}, 19.0 \mathrm{mmol})$ in anhydrous $N, N$-dimethylformamide $(46 \mathrm{~mL})$. The resultant dark yellow mixture was allowed to reach ambient temperature and stirred for $4 \mathrm{~h}$. The resultant mixture was diluted with saturated aqueous ammonium chloride $(500 \mathrm{~mL})$ and extracted with ethyl acetate $(3 \times 200 \mathrm{~mL})$. The combined extracts were dried $\left(\mathrm{MgSO}_{4}\right)$, and the solvent was removed to give the crude (5-chloro2,2',5'-trioxo-spiro[indole-3,3'-pyrrolidin]-1-yl)acetic acid tert-butyl ester, which was purified by flash chromatography (silica) eluting with petroleum ether (40-60) containing an increasing amount $(0$ to $80 \%)$ of ethyl acetate. This gave $4.76 \mathrm{~g}(95 \%)$ of a yellow solid. ${ }^{1} \mathrm{H}$ NMR (300 MHz, DMSO-d $\left.{ }_{6}\right) \delta 11.9(1 \mathrm{H}$, br s), $7.81(1 \mathrm{H}, \mathrm{d}, J$ $=2.0 \mathrm{~Hz}), 7.44(1 \mathrm{H}, \mathrm{dd}, J=8.5 \mathrm{~Hz} ; J=2.0 \mathrm{~Hz}), 7.11(1 \mathrm{H}, \mathrm{d}, J$ $=8.5 \mathrm{~Hz}), 4.52(1 \mathrm{H}, \mathrm{d}, J=18.0 \mathrm{~Hz}), 4.47(1 \mathrm{H}, \mathrm{d}, J=18.0 \mathrm{~Hz})$, $3.27(1 \mathrm{H}, \mathrm{d}, J=18.0 \mathrm{~Hz}), 2.93(1 \mathrm{H}, \mathrm{d}, J=18.0 \mathrm{~Hz}), 1.39(9 \mathrm{H}, \mathrm{s})$. MS: $309.2[\mathrm{M}-\mathrm{H}-t \mathrm{Bu}]^{+} ; 363.3[\mathrm{M}-\mathrm{H}]^{-}$.

(1'-Benzyl-5-chloro-2,2',5'-trioxospiro[indole-3,3'-pyrrolidin]1-yl)acetic Acid Ethyl Ester (51). To a stirred suspension of sodium hydride ( $60 \%$ dispersion in oil [39 $\mathrm{mg}, 0.97 \mathrm{mmol}])$ in anhydrous tetrahydrofuran $(10 \mathrm{~mL})$ was added $1^{\prime}$-benzyl-5-chloro$1 \mathrm{H}$-spiro[indole-3,3'-pyrrolidine]-2,2',5'-trione 23 (300 mg, 0.88 $\mathrm{mmol}$ ). After being stirred at ambient temperature for $30 \mathrm{~min}$, the clear solution was treated with ethyl bromoacetate $(0.13 \mathrm{~mL}, 1.2$ $\mathrm{mmol})$. The resultant suspension was stirred for $3 \mathrm{~h}$ and then left to stand overnight. Water $(50 \mathrm{~mL})$ was added, and the mixture was extracted with ethyl acetate $(3 \times 50 \mathrm{~mL})$. The combined extracts were washed with brine $(50 \mathrm{~mL})$ and dried $\left(\mathrm{MgSO}_{4}\right)$, and the solvent was removed in vacuo to give the crude (1'-benzyl-5-chloro-2, $2^{\prime}, 5^{\prime}$ trioxo-spiro[indole-3,3'-pyrrolidin]-1-yl)-acetic acid ethyl ester. Purification by flash chromatography (silica) eluting with petroleum ether containing an increasing amount (0 to 50\%) of ethyl acetate, followed by trituration with di-isopropyl ether gave the title compound as a white solid $(264 \mathrm{mg}, 70 \%), \mathrm{mp} 143-144{ }^{\circ} \mathrm{C} .{ }^{1} \mathrm{H}$ NMR $\left(300 \mathrm{MHz}, \mathrm{DMSO}-\mathrm{d}_{6}\right) \delta 7.80(1 \mathrm{H}, \mathrm{d}, J=2.0 \mathrm{~Hz}), 7.47(1 \mathrm{H}$, $\mathrm{dd}, J=8.5 \mathrm{~Hz} ; J=2.0 \mathrm{~Hz}), 7.37-7.26(5 \mathrm{H}, \mathrm{m}), 7.18(1 \mathrm{H}, \mathrm{d}, J=$ $8.5 \mathrm{~Hz}), 4.74-4.57(4 \mathrm{H}, \mathrm{m}), 4.13(2 \mathrm{H}, \mathrm{q}, J=7.0 \mathrm{~Hz}), 3.42(1 \mathrm{H}$, 
Table 12. Pharmacokinetic Profile of Selected Compounds

\begin{tabular}{|c|c|c|c|c|c|c|c|c|c|}
\hline species & & $\begin{array}{c}\text { dose } \\
(\mathrm{mpk})\end{array}$ & $\begin{array}{l}\mathrm{AUC}_{0-\text { last t }} \\
(\mathrm{h} \cdot \mathrm{ng} / \mathrm{mL})\end{array}$ & $\mathrm{Fz}(\%)$ & $\begin{array}{c}\mathrm{C} 0 \text { or } \mathrm{Cmax} \\
(\mathrm{ng} / \mathrm{mL})\end{array}$ & $\operatorname{tmax}(\mathrm{h})$ & $\mathrm{t} 1 / 2(\mathrm{~h})$ & $\mathrm{Cl}(\mathrm{L} / \mathrm{kg} / \mathrm{h})$ & Vss $(\mathrm{L} / \mathrm{kg})$ \\
\hline & & & & & $(R)-\mathbf{5 8}$ & & & & \\
\hline rat & iv & 1 & 1250 & & 1990 & 0 & 1 & 0.8 & 0.9 \\
\hline $\operatorname{dog}$ & iv & 1 & 2020 & & 2570 & 0 & 7 & 0.5 & 2 \\
\hline \multirow[t]{2}{*}{ dog } & os & 1 & 2350 & $120 \%$ & 503 & 2 & 3 & & \\
\hline & & & & & $(R)-71$ & & & & \\
\hline $\operatorname{dog}$ & iv & 1 & 637 & & 1950 & 0 & 3 & 2 & 5 \\
\hline \multirow[t]{2}{*}{ dog } & os & 1 & 339 & $52 \%$ & 68.8 & 2.67 & n.e. & & \\
\hline & & & & & $(S)-90$ & & & & \\
\hline rat & iv & 1 & 1390 & & 5060 & 0 & 0.9 & 0.7 & 0.3 \\
\hline \multirow[t]{2}{*}{ rat } & os & 5 & 319 & $5 \%$ & 55 & 1.5 & 8 & & \\
\hline & & & & & 91 & & & & \\
\hline
\end{tabular}

$\mathrm{d}, J=18.0 \mathrm{~Hz}), 3.11(1 \mathrm{H}, \mathrm{d}, J=18.0 \mathrm{~Hz}), 1.18(3 \mathrm{H}, \mathrm{t}, J=7.0$ Hz). MS: $427.2[\mathrm{M}-\mathrm{H}]^{+} ; 425.0[\mathrm{M}-\mathrm{H}]^{-}$. Anal. $\left(\mathrm{C}_{22} \mathrm{H}_{19} \mathrm{ClN}_{2} \mathrm{O}_{5}\right)$ $\mathrm{C}, \mathrm{H}, \mathrm{N}$.

General Procedure for the Synthesis of Spiro-indolinone Derivatives-Method A. Stage 1: Reaction vessels were charged with 5-chloro- $1 H$-spiro[indole-3,3'-pyrrolidine]-2,2',5'-trione 22 (500 $\mathrm{mg}, 1.90 \mathrm{mmol}$ ), anhydrous $N, N$-dimethylformamide $(3 \mathrm{~mL})$, and potassium tert-butoxide $(235 \mathrm{mg}, 1.90 \mathrm{mmol})$. After the mixtures was stirred at ambient temperature for $40 \mathrm{~min}$, the appropriate alkylating agent ( $1 \mathrm{eq}$ ) was added, and the mixtures were stirred at ambient temperature for $18 \mathrm{~h}$. Water $(25 \mathrm{~mL})$ was added, and the mixtures were extracted with ethyl acetate $(3 \times 25$ $\mathrm{mL})$. The combined extracts were dried $\left(\mathrm{MgSO}_{4}\right)$, and the solvent was removed in vacuo to give the crude products that were purified by flash chromatography (silica) eluting with petroleum ether containing an increasing amount of ethyl acetate. The products were checked by ${ }^{1} \mathrm{H} \mathrm{NMR}$, and if they were sufficiently pure, they were taken on to the next stage.

Stage 2: Each tube was charged with the appropriate product from Stage $1(0.20 \mathrm{mmol})$ and dissolved in anhydrous $\mathrm{N}, \mathrm{N}$ dimethylformamide ( $2 \mathrm{~mL}$ ). Potassium tert-butoxide $(25 \mathrm{mg}, 0.22$ $\mathrm{mmol})$ was added. Then, tert-butyl 4-bromobutyrate $(0.04 \mathrm{~mL}, 0.22$ mmol) was added, and the reaction mixtures were heated at $50{ }^{\circ} \mathrm{C}$ for $18 \mathrm{~h}$. The reactions were worked up by adding water (about 5 $\mathrm{mL})$ and extracting with ethyl acetate $(3 \times 5 \mathrm{~mL})$. The extracts were evaporated in tubes by using a Genevac HT4 for $2 \mathrm{~h}$ at 60 ${ }^{\circ} \mathrm{C}$. They were then taken on to the next stage.

Stage 3: Each of the crude products from Stage 2 were treated with a $10 \%(\mathrm{v} / \mathrm{v})$ solution of trifluoroacetic acid in anhydrous dichloromethane $(3 \mathrm{~mL})$ and stirred at ambient temperature for $72 \mathrm{~h}$. Toluene $(1 \mathrm{~mL})$ was added to each reaction mixture, the magnetic stirrer beads were removed, and the solvents were removed by using a Genevac HT4, first under vac-ramp conditions at $45{ }^{\circ} \mathrm{C}$ for 110 min and then at full vacuum at $50{ }^{\circ} \mathrm{C}$ for $45 \mathrm{~min}$. $\mathrm{N}, \mathrm{N}$ dimethylformamide $(1 \mathrm{~mL})$ was added to each tube to dissolve the residues which were transferred to a microtiter plate for automated reverse-phase preparative chromatography.

Following this procedure, the following products could be prepared:

4-[5-Chloro-1'-(2-fluorobenzyl)-2,2',5'-trioxospiro[indole-3,3'pyrrolidin]-1(2H)-yl]butanoic Acid (52). Isolated as a pale-yellow solid in $54 \%$ yield. ${ }^{1} \mathrm{H}$ NMR $\left(300 \mathrm{MHz}, \mathrm{DMSO}-\mathrm{d}_{6}\right) \delta 12.1(1 \mathrm{H}, \mathrm{br}$ s), $7.76(1 \mathrm{H}, \mathrm{d}, J=2.0 \mathrm{~Hz}), 7.48(1 \mathrm{H}, \mathrm{dd}, J=8.5 \mathrm{~Hz} ; J=2.0$ $\mathrm{Hz}), 7.40-7.16(5 \mathrm{H}, \mathrm{m}), 4.74(1 \mathrm{H}, \mathrm{d}, J=15.5 \mathrm{~Hz}), 4.68(1 \mathrm{H}, \mathrm{d}$, $J=15.5 \mathrm{~Hz}), 3.73(2 \mathrm{H}, \mathrm{m}), 3.35(1 \mathrm{H}, \mathrm{d}, J=18.0 \mathrm{~Hz}), 3.18(1 \mathrm{H}$, $\mathrm{d}, J=18.0 \mathrm{~Hz}), 2.27(2 \mathrm{H}, \mathrm{t}, J=7.0 \mathrm{~Hz}), 1.79(2 \mathrm{H}, \mathrm{m}) . \mathrm{MS}: 445.0$ $[\mathrm{M}-\mathrm{H}]^{+} ; 443.1[\mathrm{M}-\mathrm{H}]^{-}$.

4-[5-Chloro-1'-(4-methoxybenzyl)-2,2',5'-trioxospiro[indole3,3'-pyrrolidin]-1(2H)-yl]butanoic Acid (53). Isolated as a paleyellow solid in $61 \%$ yield. ${ }^{1} \mathrm{H}$ NMR (300 MHz, DMSO-d $\left.{ }_{6}\right) \delta 13.1$
(1H, br s), $7.73(1 \mathrm{H}, \mathrm{d}, J=2.0 \mathrm{~Hz}), 7.47(1 \mathrm{H}, \mathrm{dd}, J=8.5 \mathrm{~Hz} ; J$ $=2.0 \mathrm{~Hz}), 7.21(3 \mathrm{H}, \mathrm{m}), 6.90(2 \mathrm{H}, \mathrm{d}, J=8.5 \mathrm{~Hz}), 4.59(2 \mathrm{H}, \mathrm{s})$, $3.74(3 \mathrm{H}, \mathrm{s}), 3.73(2 \mathrm{H}, \mathrm{m}), 3.32(1 \mathrm{H}, \mathrm{d}, J=18.0 \mathrm{~Hz}), 3.13(1 \mathrm{H}$, $\mathrm{d}, J=18.0 \mathrm{~Hz}), 2.27(2 \mathrm{H}, \mathrm{t}, J=7.0 \mathrm{~Hz}), 1.79(2 \mathrm{H}, \mathrm{m}) . \mathrm{MS}: 457.1$ $[\mathrm{M}-\mathrm{H}]^{+} ; 455.0[\mathrm{M}-\mathrm{H}]^{-}$.

4-[5-Chloro-1'-(4-chlorobenzyl)-2,2',5'-trioxospiro[indole-3,3'pyrrolidin]-1(2H)-yl]butanoic Acid (54). Isolated as a white solid in $62 \%$ yield. ${ }^{1} \mathrm{H}$ NMR $\left(300 \mathrm{MHz}, \mathrm{DMSO}-\mathrm{d}_{6}\right) \delta 13.1(1 \mathrm{H}, \mathrm{br} \mathrm{s})$, $7.77(1 \mathrm{H}, \mathrm{d}, J=2.0 \mathrm{~Hz}), 7.48(1 \mathrm{H}, \mathrm{dd}, J=8.5 \mathrm{~Hz} ; J=2.0 \mathrm{~Hz})$, $7.42(2 \mathrm{H}, \mathrm{d}, J=8.5 \mathrm{~Hz}), 7.31(2 \mathrm{H}, \mathrm{d}, J=8.5 \mathrm{~Hz}), 7.23(1 \mathrm{H}, \mathrm{d}$, $J=8.5 \mathrm{~Hz}), 4.66(2 \mathrm{H}, \mathrm{s}), 3.73(2 \mathrm{H}, \mathrm{m}), 3.34(1 \mathrm{H}, \mathrm{d}, J=18.0$ $\mathrm{Hz}), 3.16(1 \mathrm{H}, \mathrm{d}, J=18.0 \mathrm{~Hz}), 2.26(2 \mathrm{H}, \mathrm{t}, J=7.0 \mathrm{~Hz}), 1.79(2 \mathrm{H}$, m). MS: $461.0[\mathrm{M}-\mathrm{H}]^{+} ; 459.1[\mathrm{M}-\mathrm{H}]^{-}$.

General Procedure for the Synthesis of Spiro-indolinone Derivatives-Method B. Stage 1: Each tube was charged with (5chloro-2,2',5'-trioxo-spiro[indole-3,3'-pyrrolidin]-1-yl)acetic acid tert-butyl ester $30(73 \mathrm{mg}, 0.20 \mathrm{mmol})$, potassium carbonate $(83$ $\mathrm{mg}, 0.60 \mathrm{mmol})$, and anhydrous $N, N$-dimethylformamide $(2 \mathrm{~mL})$. The appropriate alkylating agent $(0.24 \mathrm{mmol})$ was added, and the reaction mixtures were stirred at $50{ }^{\circ} \mathrm{C}$ overnight. When the alkylating agent was alpha-methyl benzyl bromide or analogues, the reaction was carried out in a CEM Discover Microwave reactor at $150{ }^{\circ} \mathrm{C}$ for $30 \mathrm{~min}$. In the cases where the alkylating agent was in the form of the hydrochloride salt, twice the normal amount of potassium carbonate was used. Each of the reaction mixtures was worked up by adding water (about $5 \mathrm{~mL}$ ) and extracting with ethyl acetate $(3 \times 5 \mathrm{~mL})$. The extracts were evaporated in tubes by using a Genevac HT4 for $2 \mathrm{~h}$ at $60{ }^{\circ} \mathrm{C}$. They were then taken on to the next stage.

Stage 2: Each of the crude products from Stage 1 were treated with a $10 \%(\mathrm{v} / \mathrm{v})$ solution of trifluoroacetic acid in anhydrous dichloromethane $(3 \mathrm{~mL})$ and stirred at ambient temperature for $72 \mathrm{~h}$. Toluene $(1 \mathrm{~mL})$ was added to each reaction mixture, the magnetic stirrer beads were removed, and the solvents were removed by using a Genevac HT4, first under vac-ramp conditions at $45^{\circ} \mathrm{C}$ for 110 min and then at full vacuum at $50{ }^{\circ} \mathrm{C}$ for $45 \mathrm{~min}$. $\mathrm{N}, \mathrm{N}$ dimethylformamide $(1 \mathrm{~mL})$ was added to each tube to dissolve the residues which were transferred to a microtiter plate for automated reverse-phase preparative chromatography.

Following this procedure, the following products could be prepared:

[5-Chloro-2,2',5'-trioxo-1' -(2-phenylethyl)spiro[indole-3,3'pyrrolidin]-1(2H)-yl]acetic Acid (55). Isolated as a brown solid in $67 \%$ yield. ${ }^{1} \mathrm{H}$ NMR $\left(300 \mathrm{MHz}, \mathrm{DMSO}_{-}\right) \delta 13.2(1 \mathrm{H}, \mathrm{br} \mathrm{s})$, $7.55(1 \mathrm{H}, \mathrm{d}, J=2.0 \mathrm{~Hz}), 7.44(1 \mathrm{H}, \mathrm{dd}, J=8.5 \mathrm{~Hz} ; J=2.0 \mathrm{~Hz})$, $7.33-7.20(5 \mathrm{H}, \mathrm{m}), 7.15(1 \mathrm{H}, \mathrm{d}, J=8.5 \mathrm{~Hz}), 4.54(1 \mathrm{H}, \mathrm{d}, J=$ $18.0 \mathrm{~Hz}), 4.48(1 \mathrm{H}, \mathrm{d}, J=18.0 \mathrm{~Hz}), 3.71(2 \mathrm{H}, \mathrm{t}, J=7.0 \mathrm{~Hz}), 3.28$ $(1 \mathrm{H}, \mathrm{d}, J=18.0 \mathrm{~Hz}), 3.01(1 \mathrm{H}, \mathrm{d}, J=18.0 \mathrm{~Hz}), 2.84(2 \mathrm{H}, \mathrm{m})$. MS: $413.1[\mathrm{M}-\mathrm{H}]^{+} ; 411.1[\mathrm{M}-\mathrm{H}]^{-}$. Anal. $\left(\mathrm{C}_{21} \mathrm{H}_{17} \mathrm{ClN}_{2} \mathrm{O}_{5}\right) \mathrm{C}$, $\mathrm{H}, \mathrm{N}$. 
[5-Chloro-2,2',5'-trioxo-1' -[(2E)-3-phenylprop-2-en-1-yl]spiro[indole-3,3'-pyrrolidin]-1(2H)-yl]acetic Acid (56). Isolated as a beige solid in $60 \%$ yield. ${ }^{1} \mathrm{H}$ NMR $\left(300 \mathrm{MHz}, \mathrm{DMSO}-\mathrm{d}_{6}\right) \delta 13.2(1 \mathrm{H}, \mathrm{br}$ s), $7.83(1 \mathrm{H}, \mathrm{d}, J=2.0 \mathrm{~Hz}), 7.47(1 \mathrm{H}, \mathrm{dd}, J=8.5 \mathrm{~Hz} ; J=2.0$ $\mathrm{Hz}), 7.41(2 \mathrm{H}, \mathrm{m}), 7.34(2 \mathrm{H}, \mathrm{t}, J=7.5 \mathrm{~Hz}), 7.26(1 \mathrm{H}, \mathrm{m}), 7.17$ $(1 \mathrm{H}, \mathrm{d}, J=8.5 \mathrm{~Hz}), 6.56(1 \mathrm{H}, \mathrm{t}, J=15.5 \mathrm{~Hz}), 6.23(1 \mathrm{H}, \mathrm{dt}, J=$ $15.5 \mathrm{~Hz} ; J=5.5 \mathrm{~Hz}), 4.56(1 \mathrm{H}, \mathrm{d}, J=18.0 \mathrm{~Hz}), 4.50(1 \mathrm{H}, \mathrm{d}, J=$ $18.0 \mathrm{~Hz}), 4.26(2 \mathrm{H}, \mathrm{m}), 3.39(1 \mathrm{H}, \mathrm{d}, J=18.0 \mathrm{~Hz}), 3.10(1 \mathrm{H}, \mathrm{d}, J$ $=18.0 \mathrm{~Hz})$. MS: $425.0[\mathrm{M}-\mathrm{H}]^{+}$; $423.1[\mathrm{M}-\mathrm{H}]^{-}$. Anal. $\left(\mathrm{C}_{22} \mathrm{H}_{17} \mathrm{ClN}_{2} \mathrm{O}_{5}\right) \mathrm{C}, \mathrm{H}, \mathrm{N}$.

[5-Chloro-2,2',5'-trioxo-1' -(1-phenylethyl)spiro[indole-3,3'pyrrolidin]-1(2H)-yl]acetic Acid (57). Isolated as a orange solid in $26 \%$ yield. ${ }^{1} \mathrm{H}$ NMR (300 MHz, DMSO- $\left.\mathrm{d}_{6}\right) \delta 13.2(1 \mathrm{H}, \mathrm{br} \mathrm{s})$, $7.83(1 \mathrm{H}, \mathrm{d}, J=2.0 \mathrm{~Hz}), 7.47(1 \mathrm{H}, \mathrm{dd}, J=8.5 \mathrm{~Hz} ; J=2.0 \mathrm{~Hz})$, $7.41(2 \mathrm{H}, \mathrm{m}), 7.34(2 \mathrm{H}, \mathrm{t}, J=7.5 \mathrm{~Hz}), 7.26(1 \mathrm{H}, \mathrm{m}), 7.17(1 \mathrm{H}, \mathrm{d}$, $J=8.5 \mathrm{~Hz}), 6.56(1 \mathrm{H}, \mathrm{t}, J=15.5 \mathrm{~Hz}), 6.23(1 \mathrm{H}, \mathrm{dt}, J=15.5 \mathrm{~Hz}$; $J=5.5 \mathrm{~Hz}), 4.56(1 \mathrm{H}, \mathrm{d}, J=18.0 \mathrm{~Hz}), 4.50(1 \mathrm{H}, \mathrm{d}, J=18.0 \mathrm{~Hz})$, $4.26(2 \mathrm{H}, \mathrm{m}), 3.39(1 \mathrm{H}, \mathrm{d}, J=18.0 \mathrm{~Hz}), 3.10(1 \mathrm{H}, \mathrm{d}, J=18.0$ Hz). MS: $413.1[\mathrm{M}-\mathrm{H}]^{+} ; 411.1[\mathrm{M}-\mathrm{H}]^{-}$. Anal. $\left(\mathrm{C}_{21} \mathrm{H}_{17} \mathrm{ClN}_{2} \mathrm{O}_{5}\right)$ $\mathrm{H}, \mathrm{N}$; C: calcd 61.10; found 60.36 .

[5-Chloro-1' -(2-fluorobenzyl)-2,2',5'-trioxospiro[indole-3,3'pyrrolidin]-1(2H)-yl]acetic Acid (58). Isolated as a beige solid in $72 \%$ yield. ${ }^{1} \mathrm{H}$ NMR $\left(300 \mathrm{MHz}, \mathrm{DMSO}-\mathrm{d}_{6}\right) \delta 13.2(1 \mathrm{H}$, br s), 7.79 $(1 \mathrm{H}, \mathrm{d}, J=2.0 \mathrm{~Hz}), 7.47(1 \mathrm{H}, \mathrm{dd}, J=8.5 \mathrm{~Hz} ; J=2.0 \mathrm{~Hz})$, $7.40-7.15(5 \mathrm{H}, \mathrm{m}), 4.74(1 \mathrm{H}, \mathrm{d}, J=15.5 \mathrm{~Hz}), 4.69(1 \mathrm{H}, \mathrm{d}, J=$ $15.5 \mathrm{~Hz}), 4.54(1 \mathrm{H}, \mathrm{d}, J=18.0 \mathrm{~Hz}), 4.49(1 \mathrm{H}, \mathrm{d}, J=18.0 \mathrm{~Hz})$, $3.41(1 \mathrm{H}, \mathrm{d}, J=18.0 \mathrm{~Hz}), 3.11(1 \mathrm{H}, \mathrm{d}, J=18.0 \mathrm{~Hz})$. MS: 417.2 $[\mathrm{M}-\mathrm{H}]^{+} ; 414.9[\mathrm{M}-\mathrm{H}]^{-}$. Anal. $\left(\mathrm{C}_{20} \mathrm{H}_{14} \mathrm{ClFN}_{2} \mathrm{O}_{5}\right) \mathrm{C}, \mathrm{H}, \mathrm{N}$.

[5-Chloro-1'-(4-fluorobenzyl)-2,2',5'-trioxospiro[indole-3,3'pyrrolidin]-1(2H)-yl]acetic Acid (59). Isolated as a beige solid in $73 \%$ yield. ${ }^{1} \mathrm{H}$ NMR $\left(300 \mathrm{MHz}, \mathrm{DMSO}-\mathrm{d}_{6}\right) \delta 13.2(1 \mathrm{H}$, br s), 7.80 $(1 \mathrm{H}, \mathrm{d}, J=2.0 \mathrm{~Hz}), 7.46(1 \mathrm{H}, \mathrm{dd}, J=8.5 \mathrm{~Hz} ; J=2.0 \mathrm{~Hz}), 7.33$ $(2 \mathrm{H}, \mathrm{dd}, J=8.5 \mathrm{~Hz} ; J=5.5 \mathrm{~Hz}), 7.21-7.15(3 \mathrm{H}, \mathrm{m}), 4.69(1 \mathrm{H}$, $\mathrm{d}, J=15.5 \mathrm{~Hz}), 4.64(1 \mathrm{H}, \mathrm{d}, J=15.5 \mathrm{~Hz}), 4.54(1 \mathrm{H}, \mathrm{d}, J=17.5$ $\mathrm{Hz}), 4.48(1 \mathrm{H}, \mathrm{d}, J=17.5 \mathrm{~Hz}), 3.40(1 \mathrm{H}, \mathrm{d}, J=18.0 \mathrm{~Hz}), 3.08$ $(1 \mathrm{H}, \mathrm{d}, J=18.0 \mathrm{~Hz})$. MS: $417.3[\mathrm{M}-\mathrm{H}]^{+} ; 415.2[\mathrm{M}-\mathrm{H}]^{-}$

[5-Chloro-1' -(3-chlorobenzyl)-2,2',5' -trioxospiro[indole-3,3'pyrrolidin]-1(2H)-yl]acetic Acid (60). Isolated as a beige solid in $61 \%$ yield. ${ }^{1} \mathrm{H}$ NMR $\left(300 \mathrm{MHz}, \mathrm{DMSO}-\mathrm{d}_{6}\right) \delta 13.2(1 \mathrm{H}$, br s), 7.80 $(1 \mathrm{H}, \mathrm{d}, J=2.0 \mathrm{~Hz}), 7.46(1 \mathrm{H}, \mathrm{dd}, J=8.5 \mathrm{~Hz} ; J=2.0 \mathrm{~Hz})$, $7.40-7.28$ (3H, m), $7.24(1 \mathrm{H}, \mathrm{d}, J=6.5 \mathrm{~Hz}), 7.16(1 \mathrm{H}, \mathrm{d}, J=8.5$ $\mathrm{Hz}), 4.70(2 \mathrm{H}, \mathrm{s}), 4.56(1 \mathrm{H}, \mathrm{d}, J=18.0 \mathrm{~Hz}), 4.47(1 \mathrm{H}, \mathrm{d}, J=18.0$ $\mathrm{Hz}), 3.41(1 \mathrm{H}, \mathrm{d}, J=18.0 \mathrm{~Hz}), 3.11(1 \mathrm{H}, \mathrm{d}, J=18.0 \mathrm{~Hz}) . \mathrm{MS}$ : $433.4[\mathrm{M}-\mathrm{H}]^{+} ; 431.4[\mathrm{M}-\mathrm{H}]^{-}$

[5-Chloro-1' -(4-chlorobenzyl)-2,2',5' -trioxospiro[indole-3,3' pyrrolidin]-1(2H)-yl]acetic Acid (61). Isolated as a white solid in $58 \%$ yield. ${ }^{1} \mathrm{H}$ NMR $\left(300 \mathrm{MHz}, \mathrm{DMSO}-\mathrm{d}_{6}\right) \delta 13.3(1 \mathrm{H}, \mathrm{br} \mathrm{s})$, $7.79(1 \mathrm{H}, \mathrm{d}, J=2.0 \mathrm{~Hz}), 7.46(1 \mathrm{H}, \mathrm{dd}, J=8.5 \mathrm{~Hz} ; J=2.0 \mathrm{~Hz})$, $7.41(2 \mathrm{H}, \mathrm{d}, J=8.5 \mathrm{~Hz}), 7.31(2 \mathrm{H}, \mathrm{d}, J=8.5 \mathrm{~Hz}), 7.16(1 \mathrm{H}, \mathrm{d}$, $J=8.5 \mathrm{~Hz}), 4.70(1 \mathrm{H}, \mathrm{d}, J=15.5 \mathrm{~Hz}), 4.65(1 \mathrm{H}, \mathrm{d}, J=15.5 \mathrm{~Hz})$, $4.53(1 \mathrm{H}, \mathrm{d}, J=17.5 \mathrm{~Hz}), 4.47(1 \mathrm{H}, \mathrm{d}, J=17.5 \mathrm{~Hz}), 3.40(1 \mathrm{H}, \mathrm{d}$, $J=18.0 \mathrm{~Hz}), 3.09(1 \mathrm{H}, \mathrm{d}, J=18.0 \mathrm{~Hz})$. MS: $433.4[\mathrm{M}-\mathrm{H}]^{+}$; $431.4[\mathrm{M}-\mathrm{H}]^{-}$. Anal. $\left(\mathrm{C}_{20} \mathrm{H}_{14} \mathrm{Cl}_{2} \mathrm{~N}_{2} \mathrm{O}_{5}\right) \mathrm{C}, \mathrm{H}, \mathrm{N}$.

[5-Chloro-1' -(2-methoxybenzyl)-2,2',5'-trioxospiro[indole-3,3'pyrrolidin]-1(2H)-yl]acetic Acid (62). Isolated as an off-white solid. ${ }^{1} \mathrm{H}$ NMR $\left(300 \mathrm{MHz}, \mathrm{DMSO}-\mathrm{d}_{6}\right) \delta 13.3(1 \mathrm{H}, \mathrm{br}$ s), $7.78(1 \mathrm{H}$, $\mathrm{d}, J=2.0 \mathrm{~Hz}), 7.46(1 \mathrm{H}, \mathrm{dd}, J=8.5 \mathrm{~Hz} ; J=2.0 \mathrm{~Hz}), 7.28(1 \mathrm{H}$, $\mathrm{td}, J=8.0 \mathrm{~Hz} ; J=1.5 \mathrm{~Hz}), 7.17(1 \mathrm{H}, \mathrm{d}, J=8.5 \mathrm{~Hz}), 7.11$ $(1 \mathrm{H}, \mathrm{dd}, J=7.5 \mathrm{~Hz} ; J=1.5 \mathrm{~Hz}), 7.02(1 \mathrm{H}, \mathrm{d}, J=7.5 \mathrm{~Hz}), 6.90$ $(1 \mathrm{H}, \mathrm{td}, J=7.5 \mathrm{~Hz} ; J=1.0 \mathrm{~Hz}), 4.65(1 \mathrm{H}, \mathrm{d}, J=15.5 \mathrm{~Hz}), 4.58$ $(1 \mathrm{H}, \mathrm{d}, J=15.5 \mathrm{~Hz}), 4.56(1 \mathrm{H}, \mathrm{d}, J=17.5 \mathrm{~Hz}), 4.50(1 \mathrm{H}, \mathrm{d}, J=$ $17.5 \mathrm{~Hz}), 3.81(3 \mathrm{H}, \mathrm{s}), 3.40(1 \mathrm{H}, \mathrm{d}, J=18.0 \mathrm{~Hz}), 3.12(1 \mathrm{H}, \mathrm{d}, J$ $=18.0 \mathrm{~Hz})$. MS: 429.1 $[\mathrm{M}-\mathrm{H}]^{+} ; 427.1[\mathrm{M}-\mathrm{H}]^{-}$. Anal. $\left(\mathrm{C}_{21} \mathrm{H}_{17} \mathrm{ClN}_{2} \mathrm{O}_{6}\right) \mathrm{C}, \mathrm{H}, \mathrm{N}$.

[5-Chloro-1' -(3-methoxybenzyl)-2,2',5'-trioxospiro[indole-3,3'pyrrolidin]-1(2H)-yl]acetic Acid (63). Isolated as a beige solid in $75 \%$ yield. ${ }^{1} \mathrm{H}$ NMR $\left(300 \mathrm{MHz}, \mathrm{DMSO}^{\left.-\mathrm{d}_{6}\right)} \delta 13.2(1 \mathrm{H}, \mathrm{br} \mathrm{s}), 7.80\right.$ $(1 \mathrm{H}, \mathrm{d}, J=2.0 \mathrm{~Hz}), 7.46(1 \mathrm{H}, \mathrm{dd}, J=8.5 \mathrm{~Hz} ; J=2.0 \mathrm{~Hz}), 7.25$ $(1 \mathrm{H}, \mathrm{t}, J=7.5 \mathrm{~Hz}), 7.17(1 \mathrm{H}, \mathrm{d}, J=8.5 \mathrm{~Hz}), 6.86-6.83(3 \mathrm{H}, \mathrm{m})$, $4.69(1 \mathrm{H}, \mathrm{d}, J=15.5 \mathrm{~Hz}), 4.63(1 \mathrm{H}, \mathrm{d}, J=15.5 \mathrm{~Hz}), 4.56(1 \mathrm{H}, \mathrm{d}$, $J=18.0 \mathrm{~Hz}), 4.49(1 \mathrm{H}, \mathrm{d}, J=18.0 \mathrm{~Hz}), 3.74(3 \mathrm{H}, \mathrm{s}), 3.41(1 \mathrm{H}$, d, $J=18.0 \mathrm{~Hz}), 3.11(1 \mathrm{H}, \mathrm{d}, J=18.0 \mathrm{~Hz}) \cdot \operatorname{MS}\left(\mathrm{ESI}^{+}\right): 429.4$ $[\mathrm{M}-\mathrm{H}]^{+} ; 427.3[\mathrm{M}-\mathrm{H}]^{-}$. Anal. $\left(\mathrm{C}_{21} \mathrm{H}_{17} \mathrm{ClN}_{2} \mathrm{O}_{6}\right) \mathrm{C}, \mathrm{H}, \mathrm{N}$.

[5-Chloro-2,2',5'-trioxo-1' -(3-phenoxybenzyl)spiro[indole-3,3'pyrrolidin]-1(2H)-yl]acetic Acid (64). Isolated as a black solid in $72 \%$ yield. ${ }^{1} \mathrm{H}$ NMR (300 MHz, DMSO-d $\left.{ }_{6}\right) \delta 13.2$ (1H, br s), 7.79 $(1 \mathrm{H}, \mathrm{d}, J=2.0 \mathrm{~Hz}), 7.46(1 \mathrm{H}, \mathrm{dd}, J=8.5 \mathrm{~Hz} ; J=2.0 \mathrm{~Hz}), 7.40$ $(2 \mathrm{H}, \mathrm{m}), 7.30(2 \mathrm{H}, \mathrm{m}), 7.15(2 \mathrm{H}, \mathrm{m}), 7.03-6.95(4 \mathrm{H}, \mathrm{m}), 4.68$ $(1 \mathrm{H}, \mathrm{d}, J=15.5 \mathrm{~Hz}), 4.63(1 \mathrm{H}, \mathrm{d}, J=15.5 \mathrm{~Hz}), 4.53(1 \mathrm{H}, \mathrm{d}, J=$ $17.5 \mathrm{~Hz}), 4.47(1 \mathrm{H}, \mathrm{d}, J=17.5 \mathrm{~Hz}), 3.40(1 \mathrm{H}, \mathrm{d}, J=18.0 \mathrm{~Hz})$, $3.09(1 \mathrm{H}, \mathrm{d}, J=18.0 \mathrm{~Hz})$. MS: $491.0[\mathrm{M}-\mathrm{H}]^{+}$; $489.1[\mathrm{M}-$ $\mathrm{H}]^{-}$. Anal. $\left(\mathrm{C}_{26} \mathrm{H}_{19} \mathrm{ClN}_{2} \mathrm{O}_{6}\right) \mathrm{C}, \mathrm{H}, \mathrm{N}$.

[5-Chloro-1' -[4-(methylsulfonyl)benzyl]-2,2',5'-trioxospiro[indole-3,3'-pyrrolidin]-1(2H)-yl]acetic Acid (65). Isolated as an offwhite solid. ${ }^{1} \mathrm{H}$ NMR $\left(300 \mathrm{MHz}, \mathrm{DMSO}-\mathrm{d}_{6}\right) \delta 13.3(1 \mathrm{H}$, br s), $7.91(2 \mathrm{H}, \mathrm{d}, J=8.0 \mathrm{~Hz}), 7.84(1 \mathrm{H}, \mathrm{d}, J=2.0 \mathrm{~Hz}), 7.56(2 \mathrm{H}, \mathrm{d}$, $J=8.0 \mathrm{~Hz}), 7.47(1 \mathrm{H}, \mathrm{dd}, J=8.5 \mathrm{~Hz} ; J=2.0 \mathrm{~Hz}), 7.18(2 \mathrm{H}, \mathrm{d}$, $J=8.5 \mathrm{~Hz}), 4.83(1 \mathrm{H}, \mathrm{d}, J=15.5 \mathrm{~Hz}), 4.77(1 \mathrm{H}, \mathrm{d}, J=15.5 \mathrm{~Hz})$, $4.55(1 \mathrm{H}, \mathrm{d}, J=17.5 \mathrm{~Hz}), 4.48(1 \mathrm{H}, \mathrm{d}, J=17.5 \mathrm{~Hz}), 3.44(1 \mathrm{H}, \mathrm{d}$, $J=18.0 \mathrm{~Hz}), 3.22(3 \mathrm{H}, \mathrm{s}), 3.13(1 \mathrm{H}, \mathrm{d}, J=18.0 \mathrm{~Hz})$. MS: 494.0 $\left[\mathrm{M}-\mathrm{NH}_{4}\right]^{+} ; 475.0[\mathrm{M}-\mathrm{H}]^{-}$

[5-Chloro-1'-(2,3-difluorobenzyl)-2,2',5'-trioxospiro[indole3,3'-pyrrolidin]-1(2H)-yl]acetic Acid (66). Isolated as a white solid. ${ }^{1} \mathrm{H}$ NMR $\left(300 \mathrm{MHz}\right.$, DMSO-d $\left.{ }_{6}\right) \delta 13.2(1 \mathrm{H}, \mathrm{br} \mathrm{s}), 7.79(1 \mathrm{H}$, $\mathrm{d}, J=2.0 \mathrm{~Hz}), 7.45(1 \mathrm{H}, \mathrm{dd}, J=8.5 \mathrm{~Hz} ; J=2.0 \mathrm{~Hz}), 7.44-7.34$ $(1 \mathrm{H}, \mathrm{m}), 7.25-7.10(3 \mathrm{H}, \mathrm{m}), 4.79(1 \mathrm{H}, \mathrm{d}, J=15.5 \mathrm{~Hz}), 4.73(1 \mathrm{H}$, $\mathrm{d}, J=15.5 \mathrm{~Hz}), 4.55(1 \mathrm{H}, \mathrm{d}, J=18.0 \mathrm{~Hz}), 4.47(1 \mathrm{H}, \mathrm{d}, J=18.0$ $\mathrm{Hz}), 3.41(1 \mathrm{H}, \mathrm{d}, J=18.0 \mathrm{~Hz}), 3.11(1 \mathrm{H}, \mathrm{d}, J=18.0 \mathrm{~Hz})$. MS: $435.0[\mathrm{M}-\mathrm{H}]^{+}$; $433.1[\mathrm{M}-\mathrm{H}]^{-}$. Anal. $\left(\mathrm{C}_{20} \mathrm{H}_{13} \mathrm{ClF}_{2} \mathrm{~N}_{2} \mathrm{O}_{5}\right) \mathrm{C}$, $\mathrm{H}, \mathrm{N}$.

[5-Chloro-1' -(2,5-difluorobenzyl)-2,2',5' -trioxospiro[indole3,3'-pyrrolidin]-1(2H)-yl]acetic Acid (67). Isolated as an off-white solid. ${ }^{1} \mathrm{H}$ NMR (300 MHz, DMSO-d 6 ) $\delta 13.2(1 \mathrm{H}, \mathrm{br} \mathrm{s}), 7.81(1 \mathrm{H}$, $\mathrm{d}, J=2.0 \mathrm{~Hz}), 7.47(1 \mathrm{H}, \mathrm{dd}, J=8.5 \mathrm{~Hz} ; J=2.0 \mathrm{~Hz}), 7.34-7.08$ $(4 \mathrm{H}, \mathrm{m}), 4.74(1 \mathrm{H}, \mathrm{d}, J=15.5 \mathrm{~Hz}), 4.69(1 \mathrm{H}, \mathrm{d}, J=15.5 \mathrm{~Hz})$, $4.56(1 \mathrm{H}, \mathrm{d}, J=18.0 \mathrm{~Hz}), 4.49(1 \mathrm{H}, \mathrm{d}, J=18.0 \mathrm{~Hz}), 3.43(1 \mathrm{H}, \mathrm{d}$, $J=18.0 \mathrm{~Hz}), 3.13(1 \mathrm{H}, \mathrm{d}, J=18.0 \mathrm{~Hz}) . \mathrm{MS}: 435.1[\mathrm{M}-\mathrm{H}]^{+}$; $433.1[\mathrm{M}-\mathrm{H}]^{-}$

[5-Chloro-1' -(3,5-difluorobenzyl)-2,2',5' -trioxospiro[indole3,3'-pyrrolidin]-1(2H)-yl]acetic Acid (68). Isolated as a white solid. ${ }^{1} \mathrm{H}$ NMR (300 MHz, DMSO-d 6 ) $\delta 13.2(1 \mathrm{H}, \mathrm{br} \mathrm{s}), 7.85(1 \mathrm{H}$, $\mathrm{d}, J=2.0 \mathrm{~Hz}), 7.47(1 \mathrm{H}, \mathrm{dd}, J=8.5 \mathrm{~Hz} ; J=2.0 \mathrm{~Hz}), 7.22-7.14$ $(2 \mathrm{H}, \mathrm{m}), 7.06-6.99(2 \mathrm{H}, \mathrm{m}), 4.73(2 \mathrm{H}, \mathrm{s}), 4.57(1 \mathrm{H}, \mathrm{d}, J=18.0$ $\mathrm{Hz}), 4.49(1 \mathrm{H}, \mathrm{d}, J=18.0 \mathrm{~Hz}), 3.44(1 \mathrm{H}, \mathrm{d}, J=18.0 \mathrm{~Hz}), 3.13$ $(1 \mathrm{H}, \mathrm{d}, J=18.0 \mathrm{~Hz})$. MS: $435.0[\mathrm{M}-\mathrm{H}]^{+}$; $433.1[\mathrm{M}-\mathrm{H}]^{-}$. Anal. $\left(\mathrm{C}_{20} \mathrm{H}_{13} \mathrm{ClF}_{2} \mathrm{~N}_{2} \mathrm{O}_{5}\right) \mathrm{C}, \mathrm{H}, \mathrm{N}$.

[5-Chloro-1'-(3,4-difluorobenzyl)-2,2',5'-trioxospiro[indole3,3'-pyrrolidin]-1(2H)-yl]acetic Acid (69). Isolated as a white solid. ${ }^{1} \mathrm{H}$ NMR $\left(300 \mathrm{MHz}, \mathrm{DMSO}-\mathrm{d}_{6}\right) \delta 13.2(1 \mathrm{H}, \mathrm{br} \mathrm{s}), 7.83(1 \mathrm{H}$, $\mathrm{d}, J=2.0 \mathrm{~Hz}), 7.49-7.30(3 \mathrm{H}, \mathrm{m}), 7.19-7.12(2 \mathrm{H}, \mathrm{m}), 4.69(2 \mathrm{H}$, s), $4.56(1 \mathrm{H}, \mathrm{d}, J=18.0 \mathrm{~Hz}), 4.49(1 \mathrm{H}, \mathrm{d}, J=18.0 \mathrm{~Hz}), 3.42(1 \mathrm{H}$, $\mathrm{d}, J=18.0 \mathrm{~Hz}), 3.11(1 \mathrm{H}, \mathrm{d}, J=18.0 \mathrm{~Hz})$. MS: $435.0[\mathrm{M}-\mathrm{H}]^{+}$; $433.1[\mathrm{M}-\mathrm{H}]^{-}$

[5-Chloro-1' -(2-chloro-5-fluorobenzyl)-2,2',5'-trioxospiro[indole-3,3'-pyrrolidin]-1(2H)-yl]acetic Acid (70). Isolated as a pale yellow gum. ${ }^{1} \mathrm{H}$ NMR (300 MHz, DMSO-d 6 ) $\delta 13.2(1 \mathrm{H}$, br s), $7.84(1 \mathrm{H}, \mathrm{d}, J=2.0 \mathrm{~Hz}), 7.58(1 \mathrm{H}, \mathrm{dd}, J=9.0 \mathrm{~Hz} ; J=5.0 \mathrm{~Hz})$, $7.48(1 \mathrm{H}, \mathrm{dd}, J=8.5 \mathrm{~Hz} ; J=2.0 \mathrm{~Hz}), 7.24(1 \mathrm{H}, \mathrm{td}, J=9.0 \mathrm{~Hz}$, $J=3.0 \mathrm{~Hz}), 7.18(1 \mathrm{H}, \mathrm{d}, J=8.5 \mathrm{~Hz}), 7.12(1 \mathrm{H}, \mathrm{dd}, J=9.0 \mathrm{~Hz}$, $J=3.0 \mathrm{~Hz}), 4.75(1 \mathrm{H}, \mathrm{d}, J=16.5 \mathrm{~Hz}), 4.69(1 \mathrm{H}, \mathrm{d}, J=16.5 \mathrm{~Hz})$, $4.57(1 \mathrm{H}, \mathrm{d}, J=18.0 \mathrm{~Hz}), 4.50(1 \mathrm{H}, \mathrm{d}, J=18.0 \mathrm{~Hz}), 3.47(1 \mathrm{H}, \mathrm{d}$, $J=18.0 \mathrm{~Hz}), 3.19(1 \mathrm{H}, \mathrm{d}, J=18.0 \mathrm{~Hz})$. MS: $451.0[\mathrm{M}-\mathrm{H}]^{+}$; $449.0[\mathrm{M}-\mathrm{H}]^{-}$

[5-Chloro-1'-(5-chloro-2-fluorobenzyl)-2,2',5'-trioxospiro[indole-3,3'-pyrrolidin]-1(2H)-yl]acetic Acid (71). Isolated as a white solid. ${ }^{1} \mathrm{H}$ NMR (300 MHz, DMSO-d $\left.{ }_{6}\right) \delta 13.2(1 \mathrm{H}, \mathrm{br} \mathrm{s}), 7.78(1 \mathrm{H}$, $\mathrm{d}, J=2.0 \mathrm{~Hz}), 7.48-7.40(2 \mathrm{H}, \mathrm{m}), 7.35-7.27(2 \mathrm{H}, \mathrm{m}), 7.16(1 \mathrm{H}$, $\mathrm{d}, J=8.5 \mathrm{~Hz}), 4.73(1 \mathrm{H}, \mathrm{d}, J=15.5 \mathrm{~Hz}), 4.68(1 \mathrm{H}, \mathrm{d}, J=15.5$ $\mathrm{Hz}), 4.55(1 \mathrm{H}, \mathrm{d}, J=18.0 \mathrm{~Hz}), 4.47(1 \mathrm{H}, \mathrm{d}, J=18.0 \mathrm{~Hz}), 3.41$ $(1 \mathrm{H}, \mathrm{d}, J=18.0 \mathrm{~Hz}), 3.11(1 \mathrm{H}, \mathrm{d}, J=18.0 \mathrm{~Hz})$. MS: $451.3[\mathrm{M}-$ $\mathrm{H}]^{+} ; 449.3[\mathrm{M}-\mathrm{H}]^{-}$. Anal. $\left(\mathrm{C}_{20} \mathrm{H}_{13} \mathrm{Cl}_{2} \mathrm{FN}_{2} \mathrm{O}_{5}\right) \mathrm{H}, \mathrm{N}$; C: calcd 53.24; found 52.55 . 
[5-Chloro-1' -(3,5-dichlorobenzyl)-2,2',5'-trioxospiro[indole3,3'-pyrrolidin]-1(2H)-yl]acetic Acid (72). Isolated as a pale brown solid. ${ }^{1} \mathrm{H}$ NMR $\left(300 \mathrm{MHz}, \mathrm{DMSO}-\mathrm{d}_{6}\right) \delta 13.3(1 \mathrm{H}, \mathrm{br} \mathrm{s}), 7.84(1 \mathrm{H}$, $\mathrm{d}, J=2.0 \mathrm{~Hz}), 7.56(1 \mathrm{H}, \mathrm{d}, J=2.0 \mathrm{~Hz}), 7.48(1 \mathrm{H}, \mathrm{dd}, J=8.5$ $\mathrm{Hz} ; J=2.0 \mathrm{~Hz}), 7.35(2 \mathrm{H}, \mathrm{d}, J=2.0 \mathrm{~Hz}), 7.17(1 \mathrm{H}, \mathrm{d}, J=8.5$ $\mathrm{Hz}), 4.73(2 \mathrm{H}$, br s), $4.56(1 \mathrm{H}, \mathrm{d}, J=17.5 \mathrm{~Hz}), 4.50(1 \mathrm{H}, \mathrm{d}, J=$ $17.5 \mathrm{~Hz}), 3.43(1 \mathrm{H}, \mathrm{d}, J=18.0 \mathrm{~Hz}), 3.13(1 \mathrm{H}, \mathrm{d}, J=18.0 \mathrm{~Hz})$. MS: $467.0[\mathrm{M}-\mathrm{H}]^{+} ; 465.1[\mathrm{M}-\mathrm{H}]^{-}$

[5-Chloro-1' -(3-chloro-5-fluorobenzyl)-2,2',5'-trioxospiro[indole-3,3'-pyrrolidin]-1(2H)-yl]acetic Acid (73). Isolated as a white solid. ${ }^{1} \mathrm{H}$ NMR $\left(300 \mathrm{MHz}, \mathrm{DMSO}-\mathrm{d}_{6}\right) \delta 13.2(1 \mathrm{H}, \mathrm{br} \mathrm{s}), 7.84(1 \mathrm{H}$, $\mathrm{d}, J=2.0 \mathrm{~Hz}), 7.47(1 \mathrm{H}, \mathrm{dd}, J=8.5 \mathrm{~Hz} ; J=2.0 \mathrm{~Hz}), 7.38(1 \mathrm{H}$, $\mathrm{dt}, J=9.0 \mathrm{~Hz} ; J=2.0 \mathrm{~Hz}), 7.25(1 \mathrm{H}, \mathrm{m}), 7.18(1 \mathrm{H}, \mathrm{d}, J=8.5$ $\mathrm{Hz}), 7.13(1 \mathrm{H}, \mathrm{d}, J=3.0 \mathrm{~Hz}), 4.73(2 \mathrm{H}, \mathrm{s}), 4.57(1 \mathrm{H}, \mathrm{d}, J=18.0$ $\mathrm{Hz}), 4.49(1 \mathrm{H}, \mathrm{d}, J=18.0 \mathrm{~Hz}), 3.43(1 \mathrm{H}, \mathrm{d}, J=18.0 \mathrm{~Hz}), 3.13$ $(1 \mathrm{H}, \mathrm{d}, J=18.0 \mathrm{~Hz})$. MS: $451.0[\mathrm{M}-\mathrm{H}]^{+} ; 449.0[\mathrm{M}-\mathrm{H}]^{-}$. Anal. $\left(\mathrm{C}_{20} \mathrm{H}_{13} \mathrm{Cl}_{2} \mathrm{FN}_{2} \mathrm{O}_{5}\right) \mathrm{C}, \mathrm{H}, \mathrm{N}$.

[5-Chloro-1'-(3-fluoro-4-methoxybenzyl)-2,2',5'-trioxospiro[indole-3,3'-pyrrolidin]-1(2H)-yl]acetic Acid (74). Isolated as a white solid. ${ }^{1} \mathrm{H}$ NMR $\left(300 \mathrm{MHz}, \mathrm{DMSO}-\mathrm{d}_{6}\right) \delta 13.2(1 \mathrm{H}, \mathrm{br} \mathrm{s}), 7.80(1 \mathrm{H}$, $\mathrm{d}, J=2.0 \mathrm{~Hz}), 7.46(1 \mathrm{H}, \mathrm{dd}, J=8.5 \mathrm{~Hz} ; J=2.0 \mathrm{~Hz}), 7.18-7.05$ $(4 \mathrm{H}, \mathrm{m}), 7.06-6.99(2 \mathrm{H}, \mathrm{m}), 4.65(1 \mathrm{H}, \mathrm{d}, J=15.5 \mathrm{~Hz}), 4.59(1 \mathrm{H}$, $\mathrm{d}, J=15.5 \mathrm{~Hz}), 4.56(1 \mathrm{H}, \mathrm{d}, J=18.0 \mathrm{~Hz}), 4.47(1 \mathrm{H}, \mathrm{d}, J=18.0$ $\mathrm{Hz}), 3.82(3 \mathrm{H}, \mathrm{s}), 3.40(1 \mathrm{H}, \mathrm{d}, J=18.0 \mathrm{~Hz}), 3.08(1 \mathrm{H}, \mathrm{d}, J=18.0$ Hz). MS: $447.0[\mathrm{M}-\mathrm{H}]^{+}$; $445.1[\mathrm{M}-\mathrm{H}]^{-}$. Anal. $\left(\mathrm{C}_{21} \mathrm{H}_{16} \mathrm{Cl}-\right.$ $\left.\mathrm{FN}_{2} \mathrm{O}_{6}\right) \mathrm{C}, \mathrm{H}, \mathrm{N}$.

[5-Chloro-1' -[(1-methyl-1H-1,2,3-benzotriazol-5-yl)methyl]2,2',5'-trioxospiro[indole-3,3'-pyrrolidin]-1(2H)-yl]acetic Acid (75). Isolated as an off-white solid. ${ }^{1} \mathrm{H}$ NMR (300 MHz, DMSO$\left.\mathrm{d}_{6}\right) \delta 13.2(1 \mathrm{H}, \mathrm{br} \mathrm{s}), 7.91(1 \mathrm{H}, \mathrm{br} \mathrm{s}), 7.87-7.82(2 \mathrm{H}, \mathrm{m}), 7.50-7.45$ $(2 \mathrm{H}, \mathrm{m}), 7.17(1 \mathrm{H}, \mathrm{d}, J=8.5 \mathrm{~Hz}), 4.89(1 \mathrm{H}, \mathrm{d}, J=15.5 \mathrm{~Hz}), 4.83$ $(1 \mathrm{H}, \mathrm{d}, J=15.5 \mathrm{~Hz}), 4.56(1 \mathrm{H}, \mathrm{d}, J=18.0 \mathrm{~Hz}), 4.48(1 \mathrm{H}, \mathrm{d}, J=$ $18.0 \mathrm{~Hz}), 4.30(3 \mathrm{H}, \mathrm{s}), 3.44(1 \mathrm{H}, \mathrm{d}, J=18.0 \mathrm{~Hz}), 3.11(1 \mathrm{H}, \mathrm{d}, J$ $=18.0 \mathrm{~Hz})$. MS: $454.1[\mathrm{M}-\mathrm{H}]^{+} ; 452.1[\mathrm{M}-\mathrm{H}]^{-}$

[5-Chloro-1' - [(2-methyl-1,3-thiazol-4-yl)methyl]-2,2',5'-trioxospiro[indole-3,3'-pyrrolidin]-1(2H)-yl]acetic Acid (76). Isolated as a white solid in $60 \%$ yield. ${ }^{1} \mathrm{H}$ NMR $\left(300 \mathrm{MHz}, \mathrm{DMSO}-\mathrm{d}_{6}\right) \delta$ $13.2(1 \mathrm{H}$, br s), $7.74(1 \mathrm{H}, \mathrm{d}, J=2.0 \mathrm{~Hz}), 7.47(1 \mathrm{H}, \mathrm{dd}, J=8.5$ $\mathrm{Hz} ; J=2.0 \mathrm{~Hz}), 7.25(1 \mathrm{H}, \mathrm{s}), 7.18(1 \mathrm{H}, \mathrm{d}, J=8.5 \mathrm{~Hz}), 4.72(2 \mathrm{H}$, s), $4.56(1 \mathrm{H}, \mathrm{d}, J=18.0 \mathrm{~Hz}), 4.49(1 \mathrm{H}, \mathrm{d}, J=18.0 \mathrm{~Hz}), 3.41(1 \mathrm{H}$, $\mathrm{d}, J=18.0 \mathrm{~Hz}), 3.14(1 \mathrm{H}, \mathrm{d}, J=18.0 \mathrm{~Hz}), 2.64(3 \mathrm{H}, \mathrm{s}) . \mathrm{MS}$ : $420.1[\mathrm{M}-\mathrm{H}]^{+} ; 418.0[\mathrm{M}-\mathrm{H}]^{-}$

[5-Chloro-1' $-\{[2-(3-$ chlorophenyl)-1,3-thiazol-4-yl]methyl $-2,2^{\prime}, 5^{\prime}$-trioxospiro[indole-3,3'-pyrrolidin]-1(2H)-yl]acetic Acid (77). Isolated as an off-white solid. ${ }^{1} \mathrm{H}$ NMR (300 MHz, DMSO$\left.\mathrm{d}_{6}\right) \delta 13.2(1 \mathrm{H}$, br s), $7.96(1 \mathrm{H}, \mathrm{m}), 7.88(1 \mathrm{H}, \mathrm{dt}, J=6.5 \mathrm{~Hz}, J=$ $2.0 \mathrm{~Hz}), 7.74(1 \mathrm{H}, \mathrm{d}, J=2.0 \mathrm{~Hz}), 7.60-7.51(3 \mathrm{H}, \mathrm{m}), 7.46(1 \mathrm{H}$, $\mathrm{dd}, J=8.5 \mathrm{~Hz} ; J=2.0 \mathrm{~Hz}), 7.18(1 \mathrm{H}, \mathrm{d}, J=8.5 \mathrm{~Hz}), 4.85(2 \mathrm{H}$, s), $4.58(1 \mathrm{H}, \mathrm{d}, J=18.0 \mathrm{~Hz}), 4.50(1 \mathrm{H}, \mathrm{d}, J=18.0 \mathrm{~Hz}), 3.46(1 \mathrm{H}$, $\mathrm{d}, J=18.0 \mathrm{~Hz}), 3.16(1 \mathrm{H}, \mathrm{d}, J=18.0 \mathrm{~Hz})$. MS: $516.0[\mathrm{M}-\mathrm{H}]^{+}$; $514.1[\mathrm{M}-\mathrm{H}]^{-}$

[5-Chloro-1' $-\{[2-(4-c h l o r o p h e n y l)-1,3-$ thiazol-4-yl]methyl $\}-2,2^{\prime}, 5^{\prime}$-trioxospiro[indole-3,3'-pyrrolidin]-1(2H)-yl]acetic Acid (78). Isolated as an off-white solid. ${ }^{1} \mathrm{H}$ NMR (300 MHz, DMSO$\left.\mathrm{d}_{6}\right) \delta 13.2(1 \mathrm{H}, \mathrm{br} \mathrm{s}), 7.94(2 \mathrm{H}, \mathrm{m}), 7.74(1 \mathrm{H}, \mathrm{d}, J=2.0 \mathrm{~Hz})$, $7.60-7.55$ (3H, m), $7.47(1 \mathrm{H}, \mathrm{dd}, J=8.5 \mathrm{~Hz} ; J=2.0 \mathrm{~Hz}), 7.18$ $(1 \mathrm{H}, \mathrm{d}, J=8.5 \mathrm{~Hz}), 4.84(2 \mathrm{H}, \mathrm{s}), 4.58(1 \mathrm{H}, \mathrm{d}, J=18.0 \mathrm{~Hz}), 4.50$ $(1 \mathrm{H}, \mathrm{d}, J=18.0 \mathrm{~Hz}), 3.46(1 \mathrm{H}, \mathrm{d}, J=18.0 \mathrm{~Hz}), 3.16(1 \mathrm{H}, \mathrm{d}, J=$ $18.0 \mathrm{~Hz}) . \mathrm{MS}: 516.1[\mathrm{M}-\mathrm{H}]^{+} ; 514.1[\mathrm{M}-\mathrm{H}]^{-}$

[5-Chloro-1' $-\{[5-(4-m e t h o x y p h e n y l)-1,2,4-o x a d i a z o l-3-y l] m e-$ thyl $\}-2,2^{\prime}, 5^{\prime}$-trioxospiro[indole-3,3'-pyrrolidin]-1(2H)-yl]acetic Acid (79). Isolated as a white solid. ${ }^{1} \mathrm{H}$ NMR $(300 \mathrm{MHz}$, DMSO $\left.\mathrm{d}_{6}\right) \delta 13.2(1 \mathrm{H}$, br s), $8.05(2 \mathrm{H}, \mathrm{m}), 7.69(1 \mathrm{H}, \mathrm{d}, J=2.0$ $\mathrm{Hz}), 7.47(1 \mathrm{H}, \mathrm{dd}, J=8.5 \mathrm{~Hz} ; J=2.0 \mathrm{~Hz}), 7.20-7.16(3 \mathrm{H}, \mathrm{m})$, $4.90(2 \mathrm{H}, \mathrm{s}), 4.58(1 \mathrm{H}, \mathrm{d}, J=18.0 \mathrm{~Hz}), 4.50(1 \mathrm{H}, \mathrm{d}, J=18.0 \mathrm{~Hz})$, $3.88(3 \mathrm{H}, \mathrm{s}), 3.46(1 \mathrm{H}, \mathrm{d}, J=18.0 \mathrm{~Hz}), 3.22(1 \mathrm{H}, \mathrm{d}, J=18.0 \mathrm{~Hz})$. MS: $497.0[\mathrm{M}-\mathrm{H}]^{+} ; 495.1[\mathrm{M}-\mathrm{H}]^{-}$. Anal. $\left(\mathrm{C}_{23} \mathrm{H}_{17} \mathrm{ClN}_{4} \mathrm{O}_{7}\right) \mathrm{H}$, $\mathrm{N}$; C: calcd 55.60; found 54.76 .

[1'-[(5-tert-Butyl-1,2,4-oxadiazol-3-yl)methyl]-5-chloro-2,2',5'trioxospiro[indole-3,3'-pyrrolidin]-1(2H)-yl]acetic Acid (80). Isolated as an off-white solid. ${ }^{1} \mathrm{H}$ NMR $\left(300 \mathrm{MHz}, \mathrm{DMSO}-\mathrm{d}_{6}\right) \delta 13.2$
(1H, br s), $7.60(1 \mathrm{H}, \mathrm{d}, J=2.0 \mathrm{~Hz}), 7.47(1 \mathrm{H}, \mathrm{dd}, J=8.5 \mathrm{~Hz} ; J$ $=2.0 \mathrm{~Hz}), 7.17(1 \mathrm{H}, \mathrm{d}, J=8.5 \mathrm{~Hz}), 4.83(2 \mathrm{H}, \mathrm{s}), 4.56(1 \mathrm{H}, \mathrm{d}, J$ $=18.0 \mathrm{~Hz}), 4.48(1 \mathrm{H}, \mathrm{d}, J=18.0 \mathrm{~Hz}), 3.43(1 \mathrm{H}, \mathrm{d}, J=18.0 \mathrm{~Hz})$, $3.21(1 \mathrm{H}, \mathrm{d}, J=18.0 \mathrm{~Hz}), 1.38(9 \mathrm{H}, \mathrm{s})$. MS: $447.1[\mathrm{M}-\mathrm{H}]^{+}$; $445.1[\mathrm{M}-\mathrm{H}]^{-}$

[5-Chloro-1'-(1,3-oxazol-2-ylmethyl)-2,2',5'-trioxospiro[indole3,3'-pyrrolidin]-1 $(2 H)$-yl]acetic Acid (81). Isolated as a white solid. ${ }^{1} \mathrm{H}$ NMR $\left(300 \mathrm{MHz}, \mathrm{DMSO}-\mathrm{d}_{6}\right) \delta 13.2(1 \mathrm{H}, \mathrm{br} \mathrm{s}), 8.11(1 \mathrm{H}$, $\mathrm{d}, J=1.0 \mathrm{~Hz}), 7.72(1 \mathrm{H}, \mathrm{d}, J=2.0 \mathrm{~Hz}), 7.46(1 \mathrm{H}, \mathrm{dd}, J=8.5$ $\mathrm{Hz} ; J=2.0 \mathrm{~Hz}), 7.19(1 \mathrm{H}, \mathrm{d}, J=1.0 \mathrm{~Hz}), 7.16(1 \mathrm{H}, \mathrm{t}, J=8.5$ $\mathrm{Hz}), 4.82(2 \mathrm{H}, \mathrm{s}), 4.54(1 \mathrm{H}, \mathrm{d}, J=18.0 \mathrm{~Hz}), 4.48(1 \mathrm{H}, \mathrm{d}, J=18.0$ $\mathrm{Hz}), 3.41(1 \mathrm{H}, \mathrm{d}, J=18.0 \mathrm{~Hz}), 3.16(1 \mathrm{H}, \mathrm{d}, J=18.0 \mathrm{~Hz})$. MS: $390.1[\mathrm{M}-\mathrm{H}]^{+} ; 388.1[\mathrm{M}-\mathrm{H}]^{-}$

[5-Chloro-1' -[(5-cyclopropyl-1,3,4-thiadiazol-2-yl)methyl]2,2',5'-trioxospiro[indole-3,3'-pyrrolidin]-1 $(2 H)$-yl]acetic Acid (82). Isolated as an off-white solid. ${ }^{1} \mathrm{H}$ NMR (300 MHz, DMSO$\left.\mathrm{d}_{6}\right) \delta 13.2(1 \mathrm{H}, \mathrm{br} \mathrm{s}), 7.75(1 \mathrm{H}, \mathrm{d}, J=2.0 \mathrm{~Hz}), 7.47(1 \mathrm{H}, \mathrm{dd}, J=$ $8.5 \mathrm{~Hz} ; J=2.0 \mathrm{~Hz}), 7.16(1 \mathrm{H}, \mathrm{d}, J=8.5 \mathrm{~Hz}), 5.05(2 \mathrm{H}, \mathrm{s}), 4.54$ $(1 \mathrm{H}, \mathrm{d}, J=18.0 \mathrm{~Hz}), 4.46(1 \mathrm{H}, \mathrm{d}, J=18.0 \mathrm{~Hz}), 3.41(1 \mathrm{H}, \mathrm{d}, J=$ $18.0 \mathrm{~Hz}), 3.12(1 \mathrm{H}, \mathrm{d}, J=18.0 \mathrm{~Hz}), 2.54(1 \mathrm{H}, \mathrm{m}), 1.20(2 \mathrm{H}, \mathrm{m})$, $1.02(2 \mathrm{H}, \mathrm{m})$. MS: 447.1 $[\mathrm{M}-\mathrm{H}]^{+}$; $445.1[\mathrm{M}-\mathrm{H}]^{-}$. Anal. $\left(\mathrm{C}_{19} \mathrm{H}_{15} \mathrm{ClN}_{4} \mathrm{O}_{5} \mathrm{~S}\right) \mathrm{H}, \mathrm{N}$; C: calcd 55.61; found 54.84.

[5-Chloro-1' -(3-furylmethyl)-2,2',5'-trioxospiro[indole-3,3'pyrrolidin]-1(2H)-yl]acetic Acid (83). Isolated as a white solid. ${ }^{1} \mathrm{H}$ NMR (300 MHz, DMSO-d 6 ) $\delta 13.2(1 \mathrm{H}$, br s), $7.77(1 \mathrm{H}, \mathrm{d}, J$ $=2.0 \mathrm{~Hz}), 7.63(1 \mathrm{H}, \mathrm{t}, J=1.5 \mathrm{~Hz}), 7.61(1 \mathrm{H}, \mathrm{m}), 7.46(1 \mathrm{H}, \mathrm{dd}$, $J=8.5 \mathrm{~Hz} ; J=2.0 \mathrm{~Hz}), 7.17(1 \mathrm{H}, \mathrm{d}, J=8.5 \mathrm{~Hz}), 6.38(1 \mathrm{H}, \mathrm{dd}$, $J=1.5, \mathrm{~Hz}, J=1.0 \mathrm{~Hz}), 4.51(4 \mathrm{H}, \mathrm{m}), 3.37(1 \mathrm{H}, \mathrm{d}, J=18.0 \mathrm{~Hz})$, $3.06(1 \mathrm{H}, \mathrm{d}, J=18.0 \mathrm{~Hz})$. MS: $389.0[\mathrm{M}-\mathrm{H}]^{+}$; $387.3[\mathrm{M}-$ $\mathrm{H}]^{-}$. Anal. $\left(\mathrm{C}_{18} \mathrm{H}_{13} \mathrm{ClN}_{2} \mathrm{O}_{6}\right) \mathrm{H}, \mathrm{N}$; C: calcd 55.61; found 54.84 .

[5-Chloro-1' -(1H-indol-3-ylmethyl)-2,2',5'-trioxospiro[indole3,3'-pyrrolidin]-1(2H)-yl]acetic Acid (84). Isolated as a brown solid. ${ }^{1} \mathrm{H}$ NMR (300 MHz, DMSO-d $\left.{ }_{6}\right) \delta 13.2(1 \mathrm{H}$, br s), 11.06 $(1 \mathrm{H}, \mathrm{s}), 7.66(1 \mathrm{H}, \mathrm{d}, J=2.0 \mathrm{~Hz}), 7.59(1 \mathrm{H}, \mathrm{d}, J=9.0 \mathrm{~Hz}), 7.44$ $(1 \mathrm{H}, \mathrm{dd}, J=8.5 \mathrm{~Hz} ; J=2.0 \mathrm{~Hz}), 7.36(1 \mathrm{H}, \mathrm{d}, J=8.0 \mathrm{~Hz}), 7.28$ $(1 \mathrm{H}, \mathrm{d}, J=2.5 \mathrm{~Hz}), 7.15(1 \mathrm{H}, \mathrm{d}, J=8.5 \mathrm{~Hz}), 7.10(1 \mathrm{H}, \mathrm{m}), 7.00$ $(1 \mathrm{H}, \mathrm{m}), 4.82(1 \mathrm{H}, \mathrm{d}, J=15.5 \mathrm{~Hz}), 4.75(1 \mathrm{H}, \mathrm{d}, J=15.5 \mathrm{~Hz})$, $4.52(1 \mathrm{H}, \mathrm{d}, J=18.0 \mathrm{~Hz}), 4.45(1 \mathrm{H}, \mathrm{d}, J=18.0 \mathrm{~Hz}), 3.35(1 \mathrm{H}, \mathrm{d}$, $J=18.0 \mathrm{~Hz}), 3.03(1 \mathrm{H}, \mathrm{d}, J=18.0 \mathrm{~Hz}) . \mathrm{MS}: 438.2[\mathrm{M}-\mathrm{H}]^{+}$; $436.1[\mathrm{M}-\mathrm{H}]^{-}$

[5-Chloro-1'-[(3,5-dimethylisoxazol-4-yl)methyl]-2,2',5'-trioxospiro[indole-3,3'-pyrrolidin]-1(2H)-yl]acetic Acid (85). Isolated as an off-white solid. ${ }^{1} \mathrm{H}$ NMR $\left(300 \mathrm{MHz}\right.$, DMSO-d $\left.\mathrm{d}_{6}\right) \delta 13.2(1 \mathrm{H}$, br s), $7.78(1 \mathrm{H}, \mathrm{d}, J=2.0 \mathrm{~Hz}), 7.45(1 \mathrm{H}, \mathrm{dd}, J=8.5 \mathrm{~Hz} ; J=2.0$ $\mathrm{Hz}), 7.15(1 \mathrm{H}, \mathrm{d}, J=8.5 \mathrm{~Hz}), 4.52(1 \mathrm{H}, \mathrm{d}, J=18.0 \mathrm{~Hz}), 4.48$ $(1 \mathrm{H}, \mathrm{d}, J=15.5 \mathrm{~Hz}), 4.46(1 \mathrm{H}, \mathrm{d}, J=18.0 \mathrm{~Hz}), 4.38(1 \mathrm{H}, \mathrm{d}, J=$ $15.5 \mathrm{~Hz}), 3.34(1 \mathrm{H}, \mathrm{d}, J=18.0 \mathrm{~Hz}), 3.01(1 \mathrm{H}, \mathrm{d}, J=18.0 \mathrm{~Hz})$, $2.38(3 \mathrm{H}, \mathrm{s}), 2.16(3 \mathrm{H}, \mathrm{s})$. MS: $418.2[\mathrm{M}-\mathrm{H}]^{+} ; 416.1[\mathrm{M}-\mathrm{H}]^{-}$.

[5-Chloro-1'-[(5-methyl-3-phenylisoxazol-4-yl)methyl]-2,2',5'trioxospiro[indole-3,3'-pyrrolidin]-1(2H)-yl]acetic Acid (86). Isolated as a white solid. ${ }^{1} \mathrm{H}$ NMR $\left(300 \mathrm{MHz}, \mathrm{DMSO}_{6}\right) \delta 13.2(1 \mathrm{H}$, br s), 7.65-7.58 (3H, m), 7.51-7.43 (4H, m), $7.14(1 \mathrm{H}, \mathrm{d}, J=$ $8.5 \mathrm{~Hz}), 4.65(1 \mathrm{H}, \mathrm{d}, J=15.5 \mathrm{~Hz}), 4.52(1 \mathrm{H}, \mathrm{d}, J=18.0 \mathrm{~Hz})$, $4.46(1 \mathrm{H}, \mathrm{d}, J=18.0 \mathrm{~Hz}), 4.45(1 \mathrm{H}, \mathrm{d}, J=15.5 \mathrm{~Hz}), 3.26(1 \mathrm{H}, \mathrm{d}$, $J=18.0 \mathrm{~Hz}), 3.00(1 \mathrm{H}, \mathrm{d}, J=18.0 \mathrm{~Hz}), 2.45(3 \mathrm{H}, \mathrm{s}) . \mathrm{MS}: 480.2$ $[\mathrm{M}-\mathrm{H}]^{+} ; 478.2[\mathrm{M}-\mathrm{H}]^{-}$

[5-Chloro-1'-[(3-methyl-5-phenylisoxazol-4-yl)methyl]-2,2',5'trioxospiro[indole-3,3'-pyrrolidin]-1(2H)-yl]acetic Acid (87). Isolated as an off-white solid. ${ }^{1} \mathrm{H}$ NMR (300 MHz, DMSO-d $\left.\mathrm{d}_{6}\right) \delta 13.2$ $(1 \mathrm{H}$, br s), $7.81(2 \mathrm{H}, \mathrm{m}), 7.68(1 \mathrm{H}, \mathrm{d}, J=2.0 \mathrm{~Hz}), 7.54(3 \mathrm{H}, \mathrm{m})$, $7.45(1 \mathrm{H}, \mathrm{dd}, J=8.5 \mathrm{~Hz} ; J=2.0 \mathrm{~Hz}), 7.14(1 \mathrm{H}, \mathrm{d}, J=8.5 \mathrm{~Hz})$, $4.78(1 \mathrm{H}, \mathrm{d}, J=15.5 \mathrm{~Hz}), 4.59(1 \mathrm{H}, \mathrm{d}, J=18.0 \mathrm{~Hz}), 4.52(1 \mathrm{H}, \mathrm{d}$, $J=18.0 \mathrm{~Hz}), 4.46(1 \mathrm{H}, \mathrm{d}, J=15.5 \mathrm{~Hz}), 3.33(1 \mathrm{H}, \mathrm{d}, J=18.0$ $\mathrm{Hz}), 3.07(1 \mathrm{H}, \mathrm{d}, J=18.0 \mathrm{~Hz}), 2.25(3 \mathrm{H}, \mathrm{s}) . \mathrm{MS}: 480.2[\mathrm{M}-$ $\mathrm{H}]^{+} ; 478.2[\mathrm{M}-\mathrm{H}]^{-}$

[5-Chloro-1'-[(4-methoxy-3,5-dimethylpyridin-2-yl)methyl]2,2',5'-trioxospiro[indole-3,3'-pyrrolidin]-1(2H)-yl]acetic Acid (88). Isolated as a white solid. ${ }^{1} \mathrm{H}$ NMR $\left(300 \mathrm{MHz}, \mathrm{DMSO}-\mathrm{d}_{6}\right) \delta$ $13.2(1 \mathrm{H}$, br s), $8.14(1 \mathrm{H}, \mathrm{s}), 7.69(1 \mathrm{H}, \mathrm{d}, J=2.0 \mathrm{~Hz}), 7.47(1 \mathrm{H}$, $\mathrm{dd}, J=8.5 \mathrm{~Hz} ; J=2.0 \mathrm{~Hz}), 7.17(1 \mathrm{H}, \mathrm{d}, J=8.5 \mathrm{~Hz}), 4.79(1 \mathrm{H}$, $\mathrm{d}, J=15.5 \mathrm{~Hz}), 4.73(1 \mathrm{H}, \mathrm{d}, J=15.5 \mathrm{~Hz}), 4.58(1 \mathrm{H}, \mathrm{d}, J=18.0$ 
$\mathrm{Hz}), 4.52(1 \mathrm{H}, \mathrm{d}, J=18.0 \mathrm{~Hz}), 3.74(3 \mathrm{H}, \mathrm{s}), 3.40(1 \mathrm{H}, \mathrm{d}, J=18.0$ $\mathrm{Hz}), 3.26(1 \mathrm{H}, \mathrm{d}, J=18.0 \mathrm{~Hz}), 2.23(3 \mathrm{H}, \mathrm{s}), 2.20(3 \mathrm{H}, \mathrm{s})$. MS: $458.2[\mathrm{M}-\mathrm{H}]^{+} ; 456.1[\mathrm{M}-\mathrm{H}]^{-}$.

Separation of Enantiomers. [(3R)-1'-Benzyl-5-chloro-2,2',5'trioxospiro[indole-3,3'-pyrrolidin]-1(2H)-yl]acetic Acid $(R)-5$. After purification by chiral preparative HPLC on a Chiralpak AD column, eluting with ethanol containing $0.05 \%$ of formic acid, the title compound was isolated as a white solid. Retention time (chiral HPLC): $5.62 \mathrm{~min}$.

[(3S)-1'-Benzyl-5-chloro-2,2',5'-trioxospiro[indole-3,3'-pyrrolidin]-1(2H)-yl]acetic Acid (S)-5. After purification by chiral preparative HPLC on a Chiralpak AD column, eluting with ethanol containing $0.05 \%$ of formic acid, the title compound was isolated as a white solid. Retention time (chiral HPLC): 8.30 min.

[(3R)-5-Chloro-1' -(2-fluorobenzyl)-2,2',5'-trioxospiro[indole3,3'-pyrrolidin]-1(2H)-yl]acetic Acid $(\boldsymbol{R})-58$. After purification by chiral preparative HPLC on a Chiralpak AD column, eluting with ethanol containing $0.05 \%$ of trifluoroacetic acid, the title compound was isolated as a white solid. Retention time (chiral HPLC): 5.22 $\min$.

[(3S)-5-Chloro-1' -(2-fluorobenzyl)-2,2',5'-trioxospiro[indole3,3'-pyrrolidin]-1(2H)-yl]acetic Acid $(S)$-58. After purification by chiral preparative HPLC on a Chiralpak AD column, eluting with ethanol containing $0.05 \%$ of trifluoroacetic acid, the title compound was isolated as a white solid. Retention time (chiral HPLC): 6.76 $\min$.

[(3R)-5-Chloro-1' -(3-chlorobenzyl)-2,2',5'-trioxospiro[indole3,3'-pyrrolidin]-1(2H)-yl]acetic Acid $(\boldsymbol{R})$-60. After purification by chiral preparative HPLC on a Chiralpak AD column, eluting with ethanol containing $0.1 \%$ of formic acid, the title compound was isolated as a white solid. Retention time (chiral HPLC): $7.23 \mathrm{~min}$.

[(3S)-5-Chloro-1' -(3-chlorobenzyl)-2,2',5'-trioxospiro[indole3,3'-pyrrolidin]-1(2H)-yl]acetic Acid $(S)-60$. After purification by chiral preparative HPLC on a Chiralpak AD column, eluting with ethanol containing $0.1 \%$ of formic acid, the title compound was isolated as a white solid. Retention time (chiral HPLC): $11.22 \mathrm{~min}$.

[(3R)-5-Chloro-1'-(3-methoxybenzyl)-2,2',5'-trioxospiro[indole3,3'-pyrrolidin]-1(2H)-yl]acetic Acid $(\boldsymbol{R})$-63. After purification by chiral preparative HPLC on a Chiralpak AD column, eluting with ethanol containing $0.2 \%$ of formic acid, the title compound was isolated as a white solid. Retention time (chiral HPLC): $5.86 \mathrm{~min}$.

[(3S)-5-Chloro-1' -(3-chlorobenzyl)-2,2',5'-trioxospiro[indole3,3'-pyrrolidin]-1(2H)-yl]acetic Acid $(S)$-63. After purification by chiral preparative HPLC on a Chiralpak AD column, eluting with ethanol containing $0.2 \%$ of formic acid, the title compound was isolated as a white solid. Retention time (chiral HPLC): $9.61 \mathrm{~min}$.

[(3R)-5-Chloro-1' - (5-chloro-2-fluorobenzyl)-2,2',5'-trioxospiro[indole-3,3'-pyrrolidin]-1(2H)-yl]acetic Acid $(\boldsymbol{R})$-71. After purification by chiral preparative HPLC on a CHIRALCEL OJ column, eluting with carbon dioxide/methanol/acetonitrile (60/32/ 8 ), the title compound was isolated as a white solid. Retention time (chiral HPLC): $12.56 \mathrm{~min}$.

[(3S)-5-Chloro-1' -(5-chloro-2-fluorobenzyl)-2,2',5'-trioxospiro[indole-3,3'-pyrrolidin]-1(2H)-yl]acetic Acid $(S)$-71. After purification by chiral preparative HPLC on a CHIRALCEL OJ column, eluting with carbon dioxide/methanol/acetonitrile (60/32/8), the title compound was isolated as a white solid. Retention time (chiral HPLC): $5.60 \mathrm{~min}$.

[(3S)-5-Chloro-1'-(5-chloro-2-fluorobenzyl)-2,5'-dioxospiro[indole-3,3'-pyrrolidin]-1(2H)-yl]acetic Acid (S)-90. After purification by chiral preparative HPLC on a Chiralpak AD column, eluting with ethanol containing $0.05 \%$ of trifluoroacetic acid, the title compound was isolated as a white solid. Retention time (chiral HPLC): $4.38 \mathrm{~min}$.

[(3R)-5-Chloro-1' -(5-chloro-2-fluorobenzyl)-2,5'-dioxospiro[indole-3,3'-pyrrolidin]-1(2H)-yl]acetic Acid (R)-90. After purification by chiral preparative HPLC on a Chiralpak AD column, eluting with ethanol containing $0.05 \%$ of trifluoroacetic acid, the title compound was isolated as a white solid. Retention time (chiral HPLC): $4.90 \mathrm{~min}$.
Methyl [5-chloro-3-(nitromethyl)-2-oxo-2,3-dihydro- $1 H$-indol3-yl](cyano)acetate (35). A suspension of methyl (2Z)-(5-chloro2-oxo-1,2-dihydro-3H-indol-3-ylidene)(cyano)acetate 20 (10.0 g; $38.1 \mathrm{mmol})$, in nitromethane $(61 \mathrm{~mL} ; 1.1 \mathrm{~mol})$ was treated with piperidine $(189 \mu \mathrm{l} ; 1.90 \mathrm{mmol})$. After being stirred for $3 \mathrm{~h}$, the mixture was diluted with ethyl acetate and filtered through silica. Evaporation of the solvent gave methyl [5-chloro-3-(nitromethyl)2-oxo-2,3-dihydro-1H-indol-3-yl](cyano)acetate as an oil (9.10 g, $73.8 \%$ ) as a mixture of diastereomers, which was used without further purification for the subsequent step. MS: $324.2[\mathrm{M}-\mathrm{H}]^{+}$; $322.2[\mathrm{M}-\mathrm{H}]^{-}$.

[5-Chloro-3-(nitromethyl)-2-oxo-2,3-dihydro-1H-indol-3-yl]acetonitrile (36). To a solution of methyl [5-chloro-3-(nitromethyl)2-oxo-2,3-dihydro-1H-indol-3-yl](cyano)acetate 35 (5.00 g; 15.4 $\mathrm{mmol})$ in $\mathrm{MeOH}(150 \mathrm{~mL})$ was added a potassium hydroxide solution in water $(9.27 \mathrm{~mL} ; 5.00 \mathrm{M} ; 46.3 \mathrm{mmol})$. After the mixture was stirred for $2.5 \mathrm{~h}$, the solvent was evaporated. The residue was taken up with ethyl acetate, the organic phase was extracted with $1 \mathrm{~N} \mathrm{HCl}$ and dried $\left(\mathrm{MgSO}_{4}\right)$, and the solvent was removed in vacuo to give the crude [5-chloro-3-(nitromethyl)-2-oxo-2,3-dihydro- $1 \mathrm{H}$ indol-3-yl](cyano)acetic acid (4.89 g, quant.) as a mixture of diastereomers, which was sufficiently pure for subsequent reaction.

A solution of [5-chloro-3-(nitromethyl)-2-oxo-2,3-dihydro- $1 \mathrm{H}$ indol-3-yl](cyano)acetic acid $(2.00 \mathrm{~g} ; 6.46 \mathrm{mmol})$ in anhydrous DMF $(15 \mathrm{~mL})$ was heated at $160{ }^{\circ} \mathrm{C}$ for $1 \mathrm{~h}$. After evaporation of the solvent, the residue was taken up in ethyl acetate, extracted with brine, and dried $\left(\mathrm{MgSO}_{4}\right)$, and the solvent was removed in vacuo to give the crude [5-chloro-3-(nitromethyl)-2-oxo-2,3dihydro- $1 H$-indol-3-yl]acetonitrile (1.74 g, quant). ${ }^{1} \mathrm{H}$ NMR (300 MHz, DMSO-d 6 ) $\delta 11.1(1 \mathrm{H}$, br s), $7.63(1 \mathrm{H}, \mathrm{d}, J=2.0 \mathrm{~Hz}), 7.35$ $(1 \mathrm{H}, \mathrm{dd}, J=8.5 \mathrm{~Hz} ; J=2.0 \mathrm{~Hz}), 6.94(1 \mathrm{H}, \mathrm{d}, J=8.5 \mathrm{~Hz}), 5.31$ $(1 \mathrm{H}, \mathrm{d}, J=14.5 \mathrm{~Hz}), 5.21(1 \mathrm{H}, \mathrm{d}, J=14.5 \mathrm{~Hz}), 3.23(1 \mathrm{H}, \mathrm{d}, J=$ $17.0 \mathrm{~Hz}), 3.10(1 \mathrm{H}, \mathrm{d}, J=17.0 \mathrm{~Hz})$. MS: $264.1[\mathrm{M}-\mathrm{H}]^{-}$.

2-[5-Chloro-3-(nitromethyl)-2-oxo-2,3-dihydro-1H-indol-3yl]acetamide (37). A solution of [5-chloro-3-(nitromethyl)-2-oxo2,3-dihydro- $1 H$-indol-3-yl]acetonitrile 36 (775 mg; $2.92 \mathrm{mmol}$ ) in THF $(6 \mathrm{~mL})$ and water $(2 \mathrm{~mL})$ was treated with acetamide $(775$ $\mathrm{mg} ; 13.1 \mathrm{mmol}$ ) and palladium(II) chloride $(51.7 \mathrm{mg} ; 0.29 \mathrm{mmol})$ and stirred overnight. Ethyl acetate was added, and the organic phase was washed with brine, dried $\left(\mathrm{MgSO}_{4}\right)$, and concentrated in vacuo to give the title compound $(740 \mathrm{mg}, 89 \%)$ that was used as such for the next step. ${ }^{1} \mathrm{H}$ NMR $\left(300 \mathrm{MHz}, \mathrm{DMSO}-\mathrm{d}_{6}\right) \delta 10.69$ $(1 \mathrm{H}, \mathrm{s}), 7.52(1 \mathrm{H}, \mathrm{d}, J=2.0 \mathrm{~Hz}), 7.33(1 \mathrm{H}, \mathrm{br} \mathrm{s}), 7.24(1 \mathrm{H}, \mathrm{dd}, J$ $=8.5 \mathrm{~Hz} ; J=2.0 \mathrm{~Hz}), 6.88(1 \mathrm{H}$, br s $), 6.82(1 \mathrm{H}, \mathrm{d}, J=8.5 \mathrm{~Hz})$, $5.34(1 \mathrm{H}, \mathrm{d}, J=14.0 \mathrm{~Hz}), 5.06(1 \mathrm{H}, \mathrm{d}, J=14.0 \mathrm{~Hz}), 2.69(1 \mathrm{H}, \mathrm{d}$, $J=15.5 \mathrm{~Hz}), 2.51(1 \mathrm{H}$, partially covered by DMSO peak). MS: $284.1[\mathrm{M}-\mathrm{H}]^{+} ; 282.1[\mathrm{M}-\mathrm{H}]^{-}$.

5-Chloro-5' $H$-spiro[indole-3,3' -pyrrolidine]-2,5' (1H)-dione (38). To an ice-cold suspension of 2-[5-chloro-3-(nitromethyl)2-oxo-2,3-dihydro- $1 H$-indol-3-yl]acetamide 37 (1.10 g; $3.88 \mathrm{mmol}$ ) in $\mathrm{AcOH}(25 \mathrm{~mL})$, zinc $(2.5 \mathrm{~g} ; 39 \mathrm{mmol})$ was added in portions over $5 \mathrm{~min}$. After the mixture was stirred for $5 \mathrm{~min}$, the ice bath was removed, and the reaction mixture was stirred for $1 \mathrm{~h}$ at room temperature. The reaction mixture was heated to reflux for $2 \mathrm{~h}$. The solvent was removed in vacuo, and the residue was purified by flash chromatography (silica) by using DCM containing increasing amounts of $\mathrm{MeOH}$ ( $3 \%$ to $20 \%$ ) to give the title compound (420 mg, 46\%) which was used as such for the next step (HPLC Method A, purity 77\%). ${ }^{1} \mathrm{H}$ NMR (300 MHz, DMSO-d 6 ) $\delta 10.6$ $(1 \mathrm{H}, \mathrm{br} \mathrm{s}), 7.96(1 \mathrm{H}, \mathrm{br} \mathrm{s}), 7.45(1 \mathrm{H}, \mathrm{d}, J=2.0 \mathrm{~Hz}), 7.25(1 \mathrm{H}, \mathrm{dd}$, $J=8.5 \mathrm{~Hz} ; J=2.0 \mathrm{~Hz}), 6.85(1 \mathrm{H}, \mathrm{d}, J=8.5 \mathrm{~Hz}), 3.46(1 \mathrm{H}, \mathrm{d}, J$ $=10.0 \mathrm{~Hz}), 3.39(1 \mathrm{H}, \mathrm{d}, J=10.0 \mathrm{~Hz}), 2.50(1 \mathrm{H}$, covered by DMSO peak), $2.44(1 \mathrm{H}, \mathrm{d}, J=16.5 \mathrm{~Hz})$. MS: $237.1[\mathrm{M}-\mathrm{H}]^{+} ; 235.1[\mathrm{M}$ $-\mathrm{H}]^{-}$

tert-Butyl (5-chloro-2,5' -dioxospiro[indole-3,3'-pyrrolidin]$\mathbf{1}(\mathbf{2 H})$-yl)acetate (39). To a solution of 5-chloro- $5^{\prime} H$-spiro[indole3,3'-pyrrolidine]-2,5'(1H)-dione 38 (230 mg; $0.97 \mathrm{mmol})$ in dry DMF $(10 \mathrm{~mL})$ was added potassium tert-butoxide $(109 \mathrm{mg} ; 0.97$ $\mathrm{mmol})$. The reaction mixture was stirred at room temperature for $30 \mathrm{~min}$ and then cooled to $0{ }^{\circ} \mathrm{C}$, and tert-butyl bromoacetate (190 $\mathrm{mg}$; $0.97 \mathrm{mmol}$ ) was added, dissolved in $3 \mathrm{~mL}$ of dry DMF. The 
reaction mixture was stirred for $1 \mathrm{~h}$ at room temperature. The solvent was evaporated in vacuo, the residue was redissolved in ethyl acetate, washed with water, and dried $\left(\mathrm{MgSO}_{4}\right)$, and the solvent was removed in vacuo. The residue was purified by flash chromatography (silica) by using cyclohexane containing increasing amounts of ethyl acetate (50\% to $100 \%$ ) to give the title compound (341 mg, 52.4\%). ${ }^{1} \mathrm{H}$ NMR (300 MHz, DMSO-d $\left.{ }_{6}\right) \delta 8.02(1 \mathrm{H}, \mathrm{br}$ s), $7.58(1 \mathrm{H}, \mathrm{d}, J=2.0 \mathrm{~Hz}), 7.36(1 \mathrm{H}, \mathrm{dd}, J=8.5 \mathrm{~Hz} ; J=2.0$ $\mathrm{Hz}), 7.04(1 \mathrm{H}, \mathrm{d}, J=8.5 \mathrm{~Hz}), 4.45(2 \mathrm{H}, \mathrm{s}), 3.48(1 \mathrm{H}, \mathrm{d}, J=10.0$ $\mathrm{Hz}), 3.43(1 \mathrm{H}, \mathrm{d}, J=10.0 \mathrm{~Hz}), 2.62(1 \mathrm{H}, \mathrm{d}, J=16.5 \mathrm{~Hz}), 2.40$ $(1 \mathrm{H}, \mathrm{d}, J=16.5 \mathrm{~Hz}), 1.38(9 \mathrm{H}, \mathrm{s}) . \mathrm{MS}: 351.1[\mathrm{M}-\mathrm{H}]^{+} ; 349.2$ $[\mathrm{M}-\mathrm{H}]^{-}$.

tert-Butyl [1'-benzyl-5-chloro-2,5' -dioxospiro[indole-3,3'-pyrrolidin]-1(2H)-yl]acetate (40a). To a solution of tert-butyl (5chloro-2,5'-dioxospiro[indole-3,3'-pyrrolidin]-1(2H)-yl)acetate 39 $(175 \mathrm{mg} ; 0.50 \mathrm{mmol})$ in dry THF $(5 \mathrm{~mL})$ was added sodium hydride (24 mg; $0.60 \mathrm{mmol}$ ). The reaction mixture was stirred for $15 \mathrm{~min}$, and benzyl bromide $(71 \mu \mathrm{l} ; 0.60 \mathrm{mmol})$ was added. After the mixture was stirred for $10 \mathrm{~min}$, the solvent was evaporated, and the residue was redissolved in ethyl acetate, washed with water and brine, dried $\left(\mathrm{MgSO}_{4}\right)$, and removed in vacuo to give a residue which was purified by chromatography (silica) eluting with cyclohexane containing increasing amounts of ethyl acetate (20 to 50\%) to give the title compound $(220 \mathrm{mg}, 52 \%) .{ }^{1} \mathrm{H}$ NMR $(300 \mathrm{MHz}$, $\left.\mathrm{CDCl}_{3}\right) \delta 7.37-7.26(5 \mathrm{H}, \mathrm{m}), 7.21(1 \mathrm{H}, \mathrm{d}, J=8.5 \mathrm{~Hz}), 7.09(1 \mathrm{H}$, br s), $6.59(1 \mathrm{H}, \mathrm{d}, J=8.5 \mathrm{~Hz}), 4.70(1 \mathrm{H}, \mathrm{d}, J=14.5 \mathrm{~Hz}), 4.42$ $(1 \mathrm{H}, \mathrm{d}, J=14.5 \mathrm{~Hz}), 4.35(1 \mathrm{H}, \mathrm{d}, J=17.5 \mathrm{~Hz}), 4.25(1 \mathrm{H}, \mathrm{d}, J=$ $17.5 \mathrm{~Hz}), 3.71(1 \mathrm{H}, \mathrm{d}, J=10.0 \mathrm{~Hz}), 3.27(1 \mathrm{H}, \mathrm{d}, J=10.0 \mathrm{~Hz})$, $3.08(1 \mathrm{H}, \mathrm{d}, J=17.0 \mathrm{~Hz}), 2.58(1 \mathrm{H}, \mathrm{d}, J=17.0 \mathrm{~Hz}), 1.40(9 \mathrm{H}, \mathrm{s})$. MS: $441.4[\mathrm{M}-\mathrm{H}]^{+} ; 439.2[\mathrm{M}-\mathrm{H}]^{-}$.

[1'-Benzyl-5-chloro-2,5' -dioxospiro[indole-3,3'-pyrrolidin]1(2H)-yl]acetatic Acid (89). A cooled $\left(0{ }^{\circ} \mathrm{C}\right)$ solution of tert-butyl (1'-benzyl-5-chloro-2,5'-dioxospiro[indole-3,3'-pyrrolidin]-1(2H)yl)acetate $40 \mathrm{a}(110.6 \mathrm{mg} ; 0.25 \mathrm{mmol})$ in DCM $(8 \mathrm{~mL})$ was treated with trifluoroacetic acid $(2.0 \mathrm{~mL})$. The solution was stirred at room temperature for $3.5 \mathrm{~h}$. The solvents were evaporated in vacuo, and the residue was taken up with toluene and evaporated in vacuo. After the mixture was dried under high vacuum for $12 \mathrm{~h}$, the title compound was obtained as a white solid $(91.9 \mathrm{mg}, 95 \%) .{ }^{1} \mathrm{H}$ NMR $\left(300 \mathrm{MHz}, \mathrm{DMSO}-\mathrm{d}_{6}\right) \delta 13.1(1 \mathrm{H}, \mathrm{br} \mathrm{s}), 7.47(1 \mathrm{H}, \mathrm{d}, J=2.0 \mathrm{~Hz})$, $7.38-7.25(6 \mathrm{H}, \mathrm{m}), 7.05(1 \mathrm{H}, \mathrm{d}, J=8.5 \mathrm{~Hz}), 4.56(1 \mathrm{H}, \mathrm{d}, J=$ $15.0 \mathrm{~Hz}), 4.43(2 \mathrm{H}, \mathrm{s}), 4.40(1 \mathrm{H}, \mathrm{d}, J=15.0 \mathrm{~Hz}), 3.49(1 \mathrm{H}, \mathrm{d}, J$ $=10.0 \mathrm{~Hz}), 3.45(1 \mathrm{H}, \mathrm{d}, J=10.0 \mathrm{~Hz}), 2.81(1 \mathrm{H}, \mathrm{d}, J=16.5 \mathrm{~Hz})$, $2.63(1 \mathrm{H}, \mathrm{d}, J=16.5 \mathrm{~Hz})$. MS: $385.3[\mathrm{M}-\mathrm{H}]^{+}$; $383.2[\mathrm{M}-$ $\mathrm{H}]^{-}$

tert-Butyl [5-chloro-1'-(5-chloro-2-fluorobenzyl)-2,5'-dioxospiro[indole-3,3'-pyrrolidin]-1(2H)-yl]acetate $(40 \mathrm{~b})$. Following the same protocol used for the preparation of 40a, starting from tert-butyl (5-chloro-2,5'-dioxospiro[indole-3,3'-pyrrolidin]-1(2H)yl)acetate 39 and 5-chloro-2-fluorobenzyl bromide, the title compound was isolated, after purification by chromatography (silica) eluting with cyclohexane containing increasing amounts of ethyl acetate (5 to $40 \%)$, as a white solid in $73 \%$ yield. ${ }^{1} \mathrm{H}$ NMR (300 $\left.\mathrm{MHz}, \mathrm{CDCl}_{3}\right) \delta 7.27(1 \mathrm{H}, \mathrm{dd}, J=6.5 \mathrm{~Hz}, J=2.0 \mathrm{~Hz}), 7.14-7.09$ $(2 \mathrm{H}, \mathrm{m}), 6.99(1 \mathrm{H}, \mathrm{d}, J=2.0 \mathrm{~Hz}), 6.87(1 \mathrm{H}, \mathrm{t}, J=9.0 \mathrm{~Hz}), 6.49$ $(1 \mathrm{H}, \mathrm{d}, J=8.5 \mathrm{~Hz}), 4.55(1 \mathrm{H}, \mathrm{d}, J=15.0 \mathrm{~Hz}), 4.36(1 \mathrm{H}, \mathrm{d}, J=$ $15.0 \mathrm{~Hz}), 4.23(1 \mathrm{H}, \mathrm{d}, J=16.0 \mathrm{~Hz}), 4.14(1 \mathrm{H}, \mathrm{d}, J=16.0 \mathrm{~Hz})$, $3.62(1 \mathrm{H}, \mathrm{d}, J=10.0 \mathrm{~Hz}), 3.21(1 \mathrm{H}, \mathrm{d}, J=10.0 \mathrm{~Hz}), 2.92(1 \mathrm{H}, \mathrm{d}$, $J=17.0 \mathrm{~Hz}), 2.45(1 \mathrm{H}, \mathrm{d}, J=17.0 \mathrm{~Hz}), 1.28(9 \mathrm{H}, \mathrm{s})$. MS: 493.4 $[\mathrm{M}-\mathrm{H}]^{+} ; 491.0[\mathrm{M}-\mathrm{H}]^{-}$.

[5-Chloro-1' -(5-chloro-2-fluorobenzyl)-2,5'-dioxospiro[indole3,3'-pyrrolidin]-1(2H)-yl]acetatic Acid (90). A cooled $\left(0{ }^{\circ} \mathrm{C}\right)$ solution of tert-butyl [5-chloro-1'-(5-chloro-2-fluorobenzyl)-2,5' dioxospiro[indole-3,3'-pyrrolidin]-1(2H)-yl]acetate 40b $(2.045 \mathrm{~g}$; $4.15 \mathrm{mmol})$ in DCM $(28 \mathrm{~mL})$ was treated with trifluoroacetic acid $(12 \mathrm{~mL})$. The solution was stirred at room temperature for $5 \mathrm{~h}$. The solution was diluted with DCM and washed with $0.1 \mathrm{~N} \mathrm{HCl}$, and the organic layer was dried over $\mathrm{MgSO}_{4}$, filtered, and evaporated to give a white residue, which was crystallized from ethanol, to give the title compound as a white solid (1.580 g, 87\%). ${ }^{1} \mathrm{H}$ NMR (300 MHz, DMSO-d 6 ) $\delta 13.2(1 \mathrm{H}$, br s), 7.54-7.52 $(2 \mathrm{H}$, m), 7.43-7.33 (2H, m), $7.27(1 \mathrm{H}, \mathrm{t}, J=9.0 \mathrm{~Hz}), 7.06(1 \mathrm{H}, \mathrm{d}, J=$ $8.5 \mathrm{~Hz}), 4.57(1 \mathrm{H}, \mathrm{d}, J=15.0 \mathrm{~Hz}), 4.46(1 \mathrm{H}, \mathrm{d}, J=15.0 \mathrm{~Hz})$, $4.45(2 \mathrm{H}, \mathrm{s}), 3.57(1 \mathrm{H}, \mathrm{d}, J=10.0 \mathrm{~Hz}), 3.51(1 \mathrm{H}, \mathrm{d}, J=10.0 \mathrm{~Hz})$, $2.84(1 \mathrm{H}, \mathrm{d}, J=16.5 \mathrm{~Hz}), 2.61(1 \mathrm{H}, \mathrm{d}, J=16.5 \mathrm{~Hz}) . \mathrm{MS}: 437.1$ $[\mathrm{M}-\mathrm{H}]^{+} ; 435.1[\mathrm{M}-\mathrm{H}]^{-}$.

tert-Butyl [5-chloro-1'-[(3-methyl-5-phenylisoxazol-4-yl)methyl]2,5'-dioxospiro[indole-3,3'-pyrrolidin]-1(2H)-yl]acetate (40c). Following the same protocol used for the preparation of 40a, starting from tert-butyl [5-chloro-1'-(2-fluorobenzyl)-2,5'-dioxospiro[indole3,3'-pyrrolidin]-1(2H)-yl]acetate 39 and 4-(bromomethyl)-3-methyl5-phenylisoxazole, the title compound was isolated, after purification by chromatography (silica) eluting with cyclohexane containing increasing amounts of ethyl acetate (10 to $50 \%)$, as a white solid in $53 \%$ yield. ${ }^{1} \mathrm{H}$ NMR $\left(300 \mathrm{MHz}, \mathrm{CDCl}_{3}\right) \delta 7.72-7.69(2 \mathrm{H}, \mathrm{m})$, 7.56-7.47 (3H, m), $7.22(1 \mathrm{H}, \mathrm{dd}, J=8.5 \mathrm{~Hz}, J=2.0 \mathrm{~Hz}), 6.87$ $(1 \mathrm{H}, \mathrm{d}, J=2.0 \mathrm{~Hz}), 6.61(1 \mathrm{H}, \mathrm{d}, J=8.5 \mathrm{~Hz}), 4.83(1 \mathrm{H}, \mathrm{d}, J=$ $15.5 \mathrm{~Hz}), 4.53(1 \mathrm{H}, \mathrm{d}, J=15.5 \mathrm{~Hz}), 4.30(2 \mathrm{H}, \mathrm{s}), 3.55(1 \mathrm{H}, \mathrm{d}, J$ $=10.0 \mathrm{~Hz}), 3.18(1 \mathrm{H}, \mathrm{d}, J=10.0 \mathrm{~Hz}), 2.99(1 \mathrm{H}, \mathrm{d}, J=17.0 \mathrm{~Hz})$, $2.57(1 \mathrm{H}, \mathrm{d}, J=17.0 \mathrm{~Hz}), 2.40(3 \mathrm{H}, \mathrm{s}), 1.41(9 \mathrm{H}, \mathrm{s})$. MS: 522.4 $[\mathrm{M}-\mathrm{H}]^{+} ; 520.1[\mathrm{M}-\mathrm{H}]^{-}$.

[5-Chloro-1'-[(3-methyl-5-phenylisoxazol-4-yl)methyl]-2,5'-dioxospiro[indole-3,3'-pyrrolidin]-1(2H)-yl]acetic Acid (91). A cooled $\left(0{ }^{\circ} \mathrm{C}\right)$ solution of tert-butyl [5-chloro-1'-[(3-methyl-5phenylisoxazol-4-yl)methyl]-2,5'-dioxospiro[indole-3,3'-pyrrolidin]$1(2 \mathrm{H})$-yl]acetate 40c $(794 \mathrm{mg} ; 1.52 \mathrm{mmol})$ in DCM $(28 \mathrm{~mL})$ was treated with trifluoroacetic acid $(12 \mathrm{~mL})$. The solution was stirred at room temperature for $6 \mathrm{~h}$. The solution was diluted with DCM and washed with $0.1 \mathrm{~N} \mathrm{HCl}$, and the organic layer was dried over $\mathrm{MgSO}_{4}$, filtered, and evaporated to give a white residue, which was crystallized from ethanol, to give the title compound as a white solid (500 mg, 71\%). ${ }^{1} \mathrm{H}$ NMR (300 MHz, DMSO-d 6 ) $\delta 13.1(1 \mathrm{H}$, br s), 7.75-7.72 (2H, m), 7.55-7.52 (3H, m), $7.42(1 \mathrm{H}, \mathrm{d}, J=$ $2.0 \mathrm{~Hz}), 7.31(1 \mathrm{H}, \mathrm{dd}, J=8.5 \mathrm{~Hz}, J=2.0 \mathrm{~Hz}), 7.03(1 \mathrm{H}, \mathrm{d}, J=$ $8.5 \mathrm{~Hz}), 4.69(1 \mathrm{H}, \mathrm{d}, J=15.0 \mathrm{~Hz}), 4.39(2 \mathrm{H}, \mathrm{s}), 4.36(1 \mathrm{H}, \mathrm{d}, J=$ $15.0 \mathrm{~Hz}), 3.48(1 \mathrm{H}, \mathrm{d}, J=9.5 \mathrm{~Hz}), 3.31(1 \mathrm{H}, \mathrm{d}, J=9.5 \mathrm{~Hz}), 2.80$ $(1 \mathrm{H}, \mathrm{d}, J=16.5 \mathrm{~Hz}), 2.56(1 \mathrm{H}, \mathrm{d}, J=16.5 \mathrm{~Hz}), 2.30(3 \mathrm{H}, \mathrm{s}) . \mathrm{MS}$ : $466.3[\mathrm{M}-\mathrm{H}]^{+} ; 464.5[\mathrm{M}-\mathrm{H}]^{-}$

Benzyl 5-chloro-2,2'-dioxospiro[indole-3,3'-pyrrolidine]-1(2H)carboxylate (46). A solution of benzyl 5-chloro-2-oxoindoline-1carboxylate $45(2.00 \mathrm{~g}$; $6.63 \mathrm{mmol})$ in dry DMF $(30 \mathrm{~mL})$ was treated with sodium hydride $(265 \mathrm{mg} ; 6.63 \mathrm{mmol})$. After $10 \mathrm{~min}$, 2-bromoethyl isocyanate $(600 \mu \mathrm{L} ; 6.63 \mathrm{mmol})$ was added. After another $10 \mathrm{~min}$, ethyl acetate was added and washed with water. The organic phase was dried $\left(\mathrm{MgSO}_{4}\right)$, and the solvent was removed in vacuo to give a solid residue that was purified by recrystallization (ethyl acetate) to give the title compound as a white solid (1.895 g, $77 \%) .{ }^{1} \mathrm{H}$ NMR $(300 \mathrm{MHz}$, DMSO-d 6$) \delta 9.45(1 \mathrm{H}$, br s), 7.74 $(1 \mathrm{H}, \mathrm{d}, J=8.5 \mathrm{~Hz}), 7.54(2 \mathrm{H}, \mathrm{m}), 7.42-7.33(3 \mathrm{H}, \mathrm{m}), 7.27(1 \mathrm{H}$, $\mathrm{d}, J=2.0 \mathrm{~Hz}), 6.98(1 \mathrm{H}, \mathrm{dd}, J=8.5 \mathrm{~Hz} ; J=2.0 \mathrm{~Hz}), 5.40(2 \mathrm{H}$, $\mathrm{s}), 4.76(2 \mathrm{H}, \mathrm{t}, J=8.5 \mathrm{~Hz}), 3.80(2 \mathrm{H}, \mathrm{t}, J=8.5 \mathrm{~Hz})$. MS: 371.1 $[\mathrm{M}-\mathrm{H}]^{+} ; 369.1[\mathrm{M}-\mathrm{H}]^{-}$.

5-Chloro-2' $H$-spiro[indole-3,3'-pyrrolidine]-2,2' $(1 H)$-dione (47). A solution of benzyl 5-chloro-2,2'-dioxospiro[indole3,3'-pyrrolidine]-1(2H)-carboxylate 46 (1.000 g; $2.70 \mathrm{mmol})$ in DMF $(50 \mathrm{~mL})$ was treated with platinum dioxide $(200 \mathrm{mg} ; 0.88$ $\mathrm{mmol})$. The mixture was placed in a hydrogenation vessel under 20 atm of hydrogen. After the mixture was stirred overnight, a further quantity of platinum dioxide $(2.50 \mathrm{~g})$ was added, and hydrogenation continued at $20 \mathrm{~atm} \mathrm{H}_{2}$ overnight. The reaction mixture was filtered on a paper filter, and the solvent was removed in vacuo to give the title compound as a gray solid $(610 \mathrm{mg}, 96 \%)$. ${ }^{1} \mathrm{H}$ NMR (300 MHz, DMSO-d $\left.\mathrm{d}_{6}\right) 10.15(1 \mathrm{H}$, br s), $9.0(1 \mathrm{H}, \mathrm{br} \mathrm{s})$, $7.12(1 \mathrm{H}, \mathrm{d}, J=2.0 \mathrm{~Hz}), 6.82(1 \mathrm{H}, \mathrm{dd}, J=8.5 \mathrm{~Hz} ; J=2.0 \mathrm{~Hz})$, $6.73(1 \mathrm{H}, \mathrm{d}, J=8.5 \mathrm{~Hz}), 4.70(2 \mathrm{H}, \mathrm{t}, J=8.5 \mathrm{~Hz}), 3.76(2 \mathrm{H}, \mathrm{t}, J$ $=8.5 \mathrm{~Hz})$. MS: $237.0[\mathrm{M}-\mathrm{H}]^{+} ; 235.0[\mathrm{M}-\mathrm{H}]^{-}$.

tert-Butyl (5-chloro-2,2'-dioxospiro[indole-3,3'-pyrrolidin]$\mathbf{1}(\mathbf{2 H})$-yl)acetate (48). A solution of 5-chloro-5' $H$-spiro[indole-3,3'pyrrolidine]-2,5'(1H)-dione $47(600 \mathrm{mg} ; 2.16 \mathrm{mmol})$ in $30 \mathrm{~mL}$ of dry DMF was treated with potassium tert-butoxide (241 mg; 2.16 $\mathrm{mmol} ; 1.00$ eq.). After $10 \mathrm{~min}$, the reaction mixture was treated with a solution of tert-butyl bromoacetate $(420 \mathrm{mg} ; 2.16 \mathrm{mmol})$ in 
$6 \mathrm{~mL}$ of dry DMF. After $4 \mathrm{~h}$, the solvent was evaporated, and the residue was dissolved in ethyl acetate. After addition of water, a solid precipitated and was filtered to give the title compound as a gray solid (225 mg, 30\%). ${ }^{1} \mathrm{H}$ NMR (300 MHz, DMSO-d $\left.\mathrm{d}_{6}\right) \delta 10.07$ $(1 \mathrm{H}, \mathrm{br} \mathrm{s}), 7.30(1 \mathrm{H}, \mathrm{d}, J=2.0 \mathrm{~Hz}), 6.84(1 \mathrm{H}, \mathrm{dd}, J=8.5 \mathrm{~Hz} ; J$ $=2.0 \mathrm{~Hz}), 6.69(1 \mathrm{H}, \mathrm{d}, J=8.5 \mathrm{~Hz}), 5.10(2 \mathrm{H}, \mathrm{s}), 4.73(2 \mathrm{H}, \mathrm{t}, J$ $=8.5 \mathrm{~Hz}), 3.84(2 \mathrm{H}, \mathrm{t}, J=8.5 \mathrm{~Hz}), 1.38(9 \mathrm{H}, \mathrm{s}) . \mathrm{MS}: 351.2[\mathrm{M}$ $-\mathrm{H}]^{+} ; 348.9[\mathrm{M}-\mathrm{H}]^{-}$

tert-Butyl [5-chloro-1'-[(5-methyl-3-phenylisoxazol-4-yl)methyl]2,2'-dioxospiro[indole-3,3'-pyrrolidin]-1(2H)-yl]acetate (49). A suspension of tert-butyl (5-chloro-2,2'-dioxospiro[indole-3,3'-pyrrolidin]-1(2H)-yl)acetate $48(100 \mathrm{mg} ; 0.29 \mathrm{mmol})$ in dry DMF (5 $\mathrm{mL}$ ) was treated with sodium hydride $(14.8 \mathrm{mg} ; 0.37 \mathrm{mmol})$. After the mixture was stirred for $20 \mathrm{~min}, 4$-(bromomethyl)-5-methyl-3phenylisoxazole ( $86 \mathrm{mg}$; $0.34 \mathrm{mmol}$ ) was added. After the mixture was stirred for $1 \mathrm{~h}$, the solvent was evaporated to give a residue, which was dissolved in ethyl acetate. The organic phase was washed with brine, dried $\left(\mathrm{MgSO}_{4}\right)$, and removed in vacuo to give a solid residue, which was purified by chromatography (silica), eluting with cyclohexane containing increasing amounts of ethyl acetate (30 to $50 \%)$ to give the title compound as a white solid $(86.0 \mathrm{mg}, 58 \%$ yield). ${ }^{1} \mathrm{H}$ NMR (300 MHz, DMSO-d $\left.{ }_{6}\right) \delta 7.62-7.59(2 \mathrm{H}, \mathrm{m})$, $7.51-7.47(3 \mathrm{H}, \mathrm{m}), 7.32(1 \mathrm{H}, \mathrm{d}, J=2.0 \mathrm{~Hz}), 6.72(1 \mathrm{H}, \mathrm{dd}, J=$ $8.5 \mathrm{~Hz} ; J=2.0 \mathrm{~Hz}), 6.28(1 \mathrm{H}, \mathrm{d}, J=8.5 \mathrm{~Hz}), 5.05(2 \mathrm{H}, \mathrm{s}), 4.85$ $(2 \mathrm{H}, \mathrm{s}), 4.75(2 \mathrm{H}, \mathrm{t}, J=8.5 \mathrm{~Hz}), 3.86(2 \mathrm{H}, \mathrm{t}, J=8.5 \mathrm{~Hz}), 2.18$ $(3 \mathrm{H}, \mathrm{s}), 1.38(9 \mathrm{H}, \mathrm{s}) . \mathrm{MS}: 522.4[\mathrm{M}-\mathrm{H}]^{+} ; 520.1[\mathrm{M}-\mathrm{H}]^{-}$.

[5-Chloro-1'-[(5-methyl-3-phenylisoxazol-4-yl)methyl]-2,2' -dioxospiro[indole-3,3'-pyrrolidin]-1(2H)-yl]acetic Acid (92). A cooled $\left(0{ }^{\circ} \mathrm{C}\right)$ solution of tert-butyl [5-chloro-1'-[(5-methyl-3phenylisoxazol-4-yl)methyl]-2,2'-dioxospiro[indole-3,3'-pyrrolidin]$1(2 \mathrm{H})$-yl]acetate $49(80 \mathrm{mg}$; $0.15 \mathrm{mmol})$ in DCM $(8 \mathrm{~mL})$ was treated with trifluoroacetic acid $(2.0 \mathrm{~mL})$. The solution was stirred at room temperature for $5 \mathrm{~h}$. The solvents were evaporated in vacuo, and the residue was taken up with toluene and evaporated in vacuo. After the mixture was dried under high vacuum for $5 \mathrm{~h}$, the title compound was obtained as an off-white solid $(65.0 \mathrm{mg}, 91 \%) .{ }^{1} \mathrm{H}$ NMR (300 MHz, DMSO-d 6$) \delta 12.9(1 \mathrm{H}$, br s), 7.60-7.57 $(2 \mathrm{H}$, m), $7.50-7.47(3 \mathrm{H}, \mathrm{m}), 7.33(1 \mathrm{H}, \mathrm{d}, J=2.0 \mathrm{~Hz}), 6.73(1 \mathrm{H}, \mathrm{dd}, J$ $=8.5 \mathrm{~Hz}, J=2.0 \mathrm{~Hz}), 6.26(1 \mathrm{H}, \mathrm{d}, J=8.5 \mathrm{~Hz}), 5.13(2 \mathrm{H}, \mathrm{s})$, $4.87(2 \mathrm{H}, \mathrm{s}), 4.75(2 \mathrm{H}, \mathrm{t}, J=8.5 \mathrm{~Hz}), 3.89(2 \mathrm{H}, \mathrm{t}, J=8.5 \mathrm{~Hz})$, $2.18(3 \mathrm{H}, \mathrm{s})$. MS: $466.3[\mathrm{M}-\mathrm{H}]^{+} ; 464.4[\mathrm{M}-\mathrm{H}]^{-}$.

Biological Assays. Construction of pCEP4-hCRTH2 Mammalian Expression Vector. Mouse CRTH2 cDNA was amplified by polymerase chain reaction by using a mouse cDNA library and cloned into the pCEP4 vector (Invitrogen Life technology, Carlsbad, CA).

Stable Transfected Cell Lines. Human chinese hamster ovary cell line expressing hCRTH2 was purchased at Euroscreen (Belgium) and cultured in HAM's F12 containing 10\% fetal calf serum (Cancerra, Australia), $50 \mu \mathrm{g} / \mathrm{mL}$ streptomycin, $50 \mathrm{U} / \mathrm{mL}$ penicillin (Invitrogen), and $400 \mu \mathrm{g} / \mathrm{mL}$ Geneticin (G418) (Calbiochem, San Diego, CA), according to the manufacturer.

Human embryonic kidney (HEK) 293(EBNA) cells (Invitrogen Life Technologies, catalog no. R620-07) were cultured in Dulbecco's modified Eagle's F-12 medium (DMEM-F-12, Invitrogen Life Technologies) containing 10\% heat inactivated fetal calf serum, 2 $\mathrm{mM}$ glutamine, 50 units $/ \mathrm{mL}$ penicillin, $50 \mu \mathrm{g} / \mathrm{mL}$ streptomycin, and $250 \mu \mathrm{g} / \mathrm{mL}$ G418 (for EBNA selection). By using the GeneJammer transfection Reagent (Stratagene, La Jolla, CA), HEK 293 (EBNA) cells were transfected with the mouse CRTH2 pCEP4 vector (containing the gene for the hygromycin resistance). Cells were maintained in culture for $48 \mathrm{~h}$ post-transfection and then grown in the presence of $300 \mu \mathrm{g} / \mathrm{mL}$ of hygromycin B (Calbiochem) for 4 weeks to select for resistant cells expressing the mCRTH2.

Membrane Preparation. Cells expressing the human and mouse CRTH2 were disrupted by nitrogen cavitation (Parr Instruments, Moline, IL) at $4{ }^{\circ} \mathrm{C}, 800 \mathrm{psi}$ for $30 \mathrm{~min}$. Membranes were prepared by differential centrifugation $(1000 \mathrm{~g}$ for $10 \mathrm{~min}$ and then $100000 \mathrm{~g}$ for $60 \mathrm{~min}$ ). Membrane pellets were resuspended in $50 \mathrm{mM}$ Tris $\mathrm{HCl} \mathrm{pH} \mathrm{7.4,} 1 \mathrm{mM}$ EDTA, and $250 \mathrm{mM}$ sucrose and stored at $-80{ }^{\circ} \mathrm{C}$.
Radioligand Binding Assay. A scintillation proximity assay was used for radioligand competition and saturation binding assays. For each assay point, 2 to $5 \mu \mathrm{g}$ of human or mouse CRTH2 cell membranes were incubated in a final volume of $100 \mu \mathrm{L}$ in 96 well plates (Corning, NY) for $90 \mathrm{~min}$ and shaken at room temperature in the presence of $100 \mu \mathrm{g}$ of wheat germ agglutinin-coated scintillation proximity assay beads (WGA-SPA, RPNQ0001, GE Healthcare), $1.5 \mathrm{nM}\left[{ }^{3} \mathrm{H}\right] \mathrm{PGD}_{2}$ (Amersham, $156 \mathrm{Cie} / \mathrm{mmol}$ ) in binding buffer (10 mM HEPES/KOH pH 7.4, $10 \mathrm{mM} \mathrm{MnCl}_{2}$, with protease inhibitor cocktail tablets). Nonspecific binding was determined in the presence of $1 \mu \mathrm{M} \mathrm{PGD}_{2}$ (Cayman, Ann Arbor, $\mathrm{MI})$. Assay was performed in the presence of $1 \%$ dimethylsulfoxide $\left(\mathrm{Me}_{2} \mathrm{SO}\right)$. Binding activity was determined by using a 1450 Microbeta scintillation counter (Wallac, UK). $K_{\mathrm{i}}$ values were calculated by using the Cheng-Prusoff equation (Cheng and Prusoff, 1973) and represent the average of at least three independentdose response experiments.

$\left[{ }^{35} \mathrm{~S}\right]$ GTP $\gamma$ S Binding Assay. The $\left[{ }^{35} \mathrm{~S}\right] \mathrm{GTP} \gamma \mathrm{S}$ binding assay was performed at $30{ }^{\circ} \mathrm{C}$ with gentle agitation in 96-well scintillating white polystyrene plates (Perkin-Elmer, Waltham, MA) in a final volume of $200 \mu \mathrm{L}$ containing $2 \%$ of $\mathrm{Me}_{2} \mathrm{SO}$.

Briefly, $10 \mu \mathrm{g}$ of membrane expressing human CRTH2 were incubated in $20 \mathrm{mM}$ HEPES/KOH pH 7.4, $10 \mathrm{mM} \mathrm{MgCl}_{2}, 10 \mu \mathrm{g}$ / $\mathrm{mL}$ Saponin, $3 \mu \mathrm{M}$ GDP, and $150 \mathrm{mM} \mathrm{NaCl}$ for $10 \mathrm{~min}$, with various concentration of PGD2. Nonspecific binding was determined in the presence of $10 \mu \mathrm{M} \mathrm{GTP} \gamma \mathrm{S}$. Antagonist activity of compounds was measured in the presence of $80 \mathrm{nM} \mathrm{PGD}$. A total of $0.15 \mathrm{nM}$ $\left[{ }^{35} \mathrm{~S}\right] \mathrm{GTP} \gamma \mathrm{S}$ (reference) was subsequently added to each sample, and after incubation of $30 \mathrm{~min}$, reactions were stopped by centrifugation at $700 \mathrm{~g}$ for $10 \mathrm{~min}$. Supernatant was removed, and $\left[{ }^{35} \mathrm{~S}\right] \mathrm{GTP} \gamma \mathrm{S}$ binding was determined by using a 1450 Microbeta scintillation counter. Data were analyzed using Prism (GraphPad Software Inc., San Diego, CA).

Human Eosinophil Chemotactic Activity. Eosinophils were purified from buffy coats of normal donors obtained from a regional hospital according to institutional guidelines of the ethical committee. Purity of the eosinophils was assessed by determining surface antigen expression or appropriate isotypic controls by using flow cytometric analysis. The purity of eosinophil preparations was $>95 \%\left(\mathrm{CD}_{16}{ }^{-}, \mathrm{CD} 11 \mathrm{~b}^{+}, \mathrm{VLA}-4^{+}, \mathrm{CCR}^{+}\right.$, and $\left.\mathrm{CRTH} 2^{+}\right)$with $>98 \%$ viability. Eosinophil chemotaxis assay was performed in Boyden chambers with a $5 \mu \mathrm{m}$ pore size polycarbonate filter. The plates were incubated at $37{ }^{\circ} \mathrm{C}, 5 \% \mathrm{CO}_{2}$, for $90 \mathrm{~min}$. Migrated cells were transferred to 96 -well plates via centrifugation by using a funnel adaptator and quantified by measuring fluorescence with a fluorescence counter. DK-PGD2, a metabolite of PGD2 that is selective for CRTH2 (100 nM), and CCL11/eotaxin (10 nM) were used as chemoattractants. Eosinophils were incubated with varying concentrations of $\mathrm{CRTH} 2$ antagonists for $30 \mathrm{~min}$ at $37{ }^{\circ} \mathrm{C}, 5 \% \mathrm{CO}_{2}$, before being applied to the chemotaxis chamber; migration toward DK-PGD2 or eotaxin was then observed.

Oxidative Metabolism. Rat and human microsomes were used to screen the metabolic instability resulting from phase I oxidation. Microsomes (final concentration $0.5 \mathrm{mg} / \mathrm{mL}$ ), $0.1 \mathrm{M}$ phosphate buffer $\mathrm{pH} 7.4$, and test compound (final concentration $3 \mu \mathrm{M}, 1 \%$ DMSO) were added to the assay plate and preincubated at $37^{\circ} \mathrm{C}$. NADPH solution (final incubation concentration of $1 \mathrm{mM}$ ) was added to initiate the reaction. The reaction was stopped by the addition of $100 \mu \mathrm{L}$ of cold acetonitrile at the appropriate time points (time $0,15,30$, and $45 \mathrm{~min}$ ). The samples were centrifuged at 5000 rpm for $5 \mathrm{~min}$ at $4{ }^{\circ} \mathrm{C}$ to precipitate the protein. Samples were analyzed by LC/MS-MS. The percentage of compound disappearance, the in vitro intrinsic clearance, was calculated, and the predicted in vivo clearance was determined. ${ }^{20}$

Cytochrome P450 Inhibition. Five human recombinant cytochrome P450 isoenzymes (BD Gentest, Woburn, MA) were tested (CYP 1A2, CYP 2C9, CYP 2C19, CYP 2D6, and CYP 3A4). Each cytochrome $\mathrm{P} 450$ isoenzyme converts a specific fluorogenic substrate to a fluorescent product by the enzymatic activity. Test compound (up to final incubation concentration of $10 \mu \mathrm{M}$ ) in $1 \%$ DMSO was added to the incubation mixture. The fluorescence 
intensity after a defined reaction time serves as the readout (Multilabel Counter VICTOR2, EG\&G WALLAC, Turku, Finland). For each compound, the inhibition percentage at each concentration and the $\mathrm{IC}_{50}$ were estimated.

Caco-2 Permeability. Caco-2 cells were obtained from American type culture collection (Rockville, MD). The cells were seeded onto a 24-well polycarbonate filter membrane (Transwell inserts, surface area: $0.33 \mathrm{~cm}^{2}$, Corning) at a cell density of $1 \times 10^{5} \mathrm{cell} / \mathrm{cm}^{2}$ and grown in Dulbecco's modified Eagle's medium supplemented with $10 \%$ fetal bovine serum, $1 \%$ nonessential amino acids, and $1 \%$ L-glutamine. Permeability studies were performed with the monolayers cultured for 21 days. Prior to all experiments, the cell monolayer integrity was evaluated by trans epithelial electrical resistance; values greater than $800 \mathrm{ohm} \cdot \mathrm{cm}^{2}$ were used. The permeability studies were initiated by adding an appropriate volume of Hank's balanced salt solution buffer containing $10 \mu \mathrm{M}$ test compound to either the apical (for apical to basolateral transport; A to B) or basolateral (for basolateral to apical transport; B to A) side of the monolayer. The monolayers were then placed in an incubator at $37^{\circ} \mathrm{C}$. At the end of the incubation time $(2 \mathrm{~h})$, samples were taken from both the apical and basolateral compartments. The concentrations of test compound were analyzed by LC/MS-MS. The permeability coefficient (Papp) was calculated according to the following equation: $\operatorname{Papp}=(\mathrm{d} A / \mathrm{d} t)\left(1 / S C_{0}\right)$, where $\mathrm{d} A / \mathrm{d} t$ is the flux of the test compound across the monolayer (nmol/s), $S$ is the surface area of the cell monolayer $\left(\mathrm{cm}^{2}\right)$, and $C_{0}$ is the initial concentration $(\mu \mathrm{M})$ in the donor compartment.

In vivo Pharmacokinetic Studies. Rat. The test compound was administered orally by gavage or as an intravenous bolus dose to three male Sprague-Dawley or Janvier rats per dose route. Serial blood samples were collected via an indwelling carotid catheter up to $24 \mathrm{~h}$ post dose.

Dog. The test compound was administered orally by gavage and as an intravenous bolus dose to three male beagle dogs in a crossover study design. Each dog received $1 \mathrm{mg} / \mathrm{kg}$ of compound formulated as a solution. Serial blood samples were collected up to $48 \mathrm{~h}$ post dose. For both species, plasma samples (pooled by time point for rat, individual for dog) were analyzed by LC-MS/ MS. Pharmacokinetic parameters were determined by using noncompartmental analysis.

Acknowledgment. Y.F. is grateful to SNBL for the provision of the in-house beam time.

Supporting Information Available: Analytical data related to the chemical purity of compounds 5, 29, and 51-92. Full structural details for the crystal structures of $(R)-\mathbf{5},(R)-\mathbf{5 8}$, and $(S)-\mathbf{9 0}$ in the CIF format. This material is available free of charge via the Internet at http://pubs.acs.org.

\section{References}

(1) Pettipher, R.; Hansel, T. T.; Armer, R. Antagonism of the prostaglandin $\mathrm{D} 2$ receptors DP1 and CRTH2 as an approach to treat allergic diseases. Nat. Rev. Drug Discovery 2007, 6, 313-325.

(2) Hirai, H.; Tanaka, K.; Yoshie, O.; Ogawa, K.; Kenmotsu, K.; Takamori, Y.; Ichimasa, M.; Sugamura, K.; Nakamura, M.; Takano, S.; Nagata, K. Prostaglandin D2 selectively induces chemotaxis in T helper type 2 cells eosinophils and basophils via 7-transmembrane receptor CRTH2. J. Exp. Med. 2002, 193, 255-261.

(3) Shiraishi, Y.; Asano, K.; Nakajima, T.; Oguma, T.; Suzuki, Y.; Shiomi, T.; Sayama, K.; Niimi, K.; Wakaki, M.; Kagyo, J.; Ikeda, E.; Hirai, H.; Yamaguchi, K.; Ishizaka, A. Prostaglandin D2-induced eosinophilic airways inflammation is mediated by CRTH2 receptor. J. Pharmacol. Exp. Ther. 2005, 312, 954-960.

(4) Iwasaki, M.; Nagata, K.; Takano, S.; Takahashi, K.; Ishii, N.; Ikezawa, Z. Association of a new type prostaglandin D2 receptor CRTH2 with circulating Thelper 2 cells in patients with atopic dermatitis. J. Invest. Dermatol. 2002, 119, 609-616.

(5) Luster, A. D.; Tager, A. M. T-cell trafficking in asthma: Lipid mediators grease the way. Nat. Rev. Immunol. 2004, 4, 711-724.

(6) Hammad, H.; de Heer, H. J.; Soullie, T.; Hoogsteden, H. C.; Trottein, F.; Lambrecht, B. N. Prostaglandin $\mathrm{D}_{2}$ inhibits airway dendritic cell migration and function in steady state conditions by selective activation of the D prostanoid receptor 1. J. Immunol. 2003, 171, 3936-3940.

(7) Cosmi, L.; Annunziato, F.; Galli, M. I. G.; Maggi, R. M. E.; Nagata, $\mathrm{K}$; Romagnani, S. CRTH2 is the most reliable marker for the detection of circulating human type $2 \mathrm{Th}$ and type $2 \mathrm{~T}$ cytotoxic cells in health and disease. Eur. J. Immunol. 2000, 30, 2972-2979.

(8) Huang, J. L.; Gao, P. S.; Mathias, R. A.; Yao, T. C.; Chen, L. C.; Kuo, M. L.; Hsu, S. C.; Plunkett, B.; Togias, A.; Barnes, K. C.; Stellato, C.; Beaty, T. H.; Huang, S. K. Sequence variants of the gene encoding chemoattractant receptor expressed on Th2 cells (CRTH2) are associated with asthma and differentially influence mRNA stability. Hum. Mol. Genet. 2004, 13, 2691-2697.

(9) Heinemann, A.; Schuligoi, R.; Sabroe, I.; Hartnell, A.; Peskar, B. A. Delta 12-prostaglandin J2, a plasma metabolite of prostaglandin D2, causes eosinophil mobilization from the bone marrow and primes eosinophils for chemotaxis. J. Immunol. 2003, 170, 4752-4758.

(10) Spik, I.; Brenuchon, C.; Angeli, V.; Staumont, D.; Fleury, S.; Capron, M.; Trottein, F.; Dombrowicz, D. Activation of prostaglandin D2 receptor DP2/CRTH2 increases allergic inflammation in mouse. J. Immunol. 2005, 174, 3703-3708.

(11) Almishri, W.; Cossette, C.; Rokach, J.; Martin, J. G.; Hamid, Q.; Powell, W. S. Effects of prostaglandin D2, 15-deoxy-delta ${ }^{12,14}$ prostaglandinJ2, and selective DP1 and DP2 receptor agonists on pulmonary infiltration of eosinophils in Brown Norway rats. J. Pharm. Exp. Ther. 2005, 313, 64-69.

(12) Takeshita, K.; Yamasaki, T.; Nagao, K.; Sugimoto, H.; Shichijo, M.; Gantner, F.; Bacon, K. B. CRTH2 is a prominent effector in contact hypersensitivity-induced neutrophil inflammation. Int. Immunol. 2004, 16, 947-959.

(13) Chevalier, E.; Stock, J.; Fisher, T.; Dupont, M.; Fric, M.; Fargeau, H.; Leport, M.; Soler, S.; Fabien, S.; Pruniaux, M. P.; Fink, M.; Bertrand, C. P.; McNeish, J.; Li, B. Cutting edge: Chemoattractant receptor-homologous molecule expressed on $\mathrm{TH} 2$ cells plays a restricting role on IL-5 production and eosinophil recruitment. J. Immunol. 2005, 175, 2056-2060.

(14) Kostenis, E.; Ulven, T. Emerging roles of DP and CRTH2 in allergic inflammation. Trends Mol. Med. 2006, 12, 148-158.

(15) Schuligoi, R.; Schmidt, R.; Geisslinger, G.; Kollroser, M.; Peskar, B. A.; Heinemann, A. PGD2 metabolism in plasma: Kinetics and relationship with bioactivity on DP1 and CRTH2 receptors. Biochem. Pharmacol. 2007, 74, 107-117.

(16) Ly, T. W.; Bacon, K. B. Small-molecule CRTH2 antagonists for the treatment of allergic inflammation: An overview. Expert Opin. Investig. Drugs 2005, 14, 769-773.

(17) Maffioli, S. I.; Marzorati, E.; Marazzi, A. Mild and reversible dehydration of primary amides with $\mathrm{PdCl}_{2}$ in aqueous acetonitrile. Org. Lett. 2005, 7, 5237-5239.

(18) Porcs-Makkay, M.; Argay, G.; Kàlmàn, A.; Simig, G. Synthesis of 1,3-di[(alkoxy(aryloxy)carbonyl]-2-oxo-2,3-dihydroindoles. Tetrahedron 2000, 56, 5893-5903.

(19) Gervais, F. G.; Morello, J. P.; Beaulieu, C.; Sawyer, N.; Denis, D.; Greig, G.; Malebranche, A. D.; O'Neill, G. P. Identification of a potent and selective synthetic agonist at the CRTH2 receptor. Mol. Pharmacol. 2005, 67, 1834-1839.

(20) Lave, T. H.; Dupin, S.; Schmitt, C.; Chou, R. C.; Jack, D.; Coassolo, P. H. Integration of in vitro data into allometric scaling to predict hepatic metabolic clearance in man: Application to 10 extensively metabolized drugs. J. Pharm. Sci. 1997, 86, 584-590.

JM701383E 